\title{
Gq-Coupled Muscarinic Receptor Enhancement of KCNQ2/3 Channels and Activation of TRPC Channels in Multimodal Control of Excitability in Dentate Gyrus Granule Cells
}

\author{
(DChase M. Carver and $\oplus^{-M a r k ~ S . ~ S h a p i r o ~}$ \\ Department of Cellular and Integrative Physiology, University of Texas Health San Antonio, Texas 78229
}

KCNQ (Kv7, "M-type") $\mathrm{K}^{+}$channels and TRPC (transient receptor potential, "canonical") cation channels are coupled to neuronal discharge properties and are regulated via $\mathrm{G}_{\mathrm{q} / 11}$-protein-mediated signals. Stimulation of $\mathrm{G}_{\mathrm{q} / 11}$-coupled receptors both consumes phosphatidylinositol 4,5-bisphosphate $\left(\mathrm{PIP}_{2}\right)$ via phosphalipase $\mathrm{C} \beta$ hydrolysis and stimulates $\mathrm{PIP}_{2}$ synthesis via rises in $\mathrm{Ca}^{2+}{ }_{\mathrm{i}}$ and other signals. Using brain-slice electrophysiology and $\mathrm{Ca}^{2+}$ imaging from male and female mice, we characterized threshold $\mathrm{K}^{+}$currents in dentate gyrus granule cells (DGGCs) and CA1 pyramidal cells, the effects of $\mathrm{G}_{\mathrm{q} / 11}$-coupled muscarinic $\mathrm{M}_{1}$ acetylcholine $\left(\mathrm{M}_{1} \mathrm{R}\right)$ stimulation on $\mathrm{M}$ current and on neuronal discharge properties, and elucidated the intracellular signaling mechanisms involved. We observed disparate signaling cascades between DGGCs and CA1 neurons. DGGCs displayed $\mathrm{M}_{1} \mathrm{R}$ enhancement of $\mathrm{M}$-current, rather than suppression, due to stimulation of $\mathrm{PIP}_{2}$ synthesis, which was paralleled by increased $\mathrm{PIP}_{2}$-gated G-protein coupled inwardly rectifying $\mathrm{K}^{+}$ currents as well. Deficiency of KCNQ2-containing M-channels ablated the $\mathrm{M}_{1} \mathrm{R}$-induced enhancement of M-current in DGGCs. Simultaneously, $\mathrm{M}_{1} \mathrm{R}$ stimulation in DGGCs induced robust increases in $\left[\mathrm{Ca}^{2+}\right]_{\mathrm{i}}$, mostly due to TRPC currents, consistent with, and contributing to, neuronal depolarization and hyperexcitability. CA1 neurons did not display such multimodal signaling, but rather M current was suppressed by $M_{1} R$ stimulation in these cells, similar to the previously described actions of $M_{1} R$ stimulation on $M$-current in peripheral ganglia that mostly involves PIP $_{2}$ depletion. Therefore, these results point to a pleiotropic network of cholinergic signals that direct cell-type-specific, precise control of hippocampal function with strong implications for hyperexcitability and epilepsy.

Key words: electrophysiology; hippocampus; hyperexcitability; muscarinic receptors; potassium channel; signal transduction

Significance Statement

At the neuronal membrane, protein signaling cascades consisting of ion channels and metabotropic receptors govern the electrical properties and neurotransmission of neuronal networks. Muscarinic acetylcholine receptors are G-protein-coupled metabotropic receptors that control the excitability of neurons through regulating ion channels, intracellular $\mathrm{Ca}^{2+}$ signals, and other secondmessenger cascades. We have illuminated previously unknown actions of muscarinic stimulation on the excitability of hippocampal principal neurons that include M channels, TRPC (transient receptor potential, "canonical") cation channels, and powerful regulation of lipid metabolism. Our results show that these signaling pathways, and mechanisms of excitability, are starkly distinct between peripheral ganglia and brain, and even between different principal neurons in the hippocampus.

\section{Introduction}

Voltage-gated "M-type" (KCNQ, Kv7) $\mathrm{K}^{+}$channels are ubiquitously expressed in the nervous system, where they regulate neuronal resting membrane potential, spike-frequency adaptation

\footnotetext{
Received July 13, 2018; revised Dec. 17, 2018; accepted Dec. 20, 2018.

Author contributions: C.M.C. wrote the first draft of the paper; C.M.C. and M.S.S. edited the paper; C.M.C. and M.S.S. designed research; C.M.C. performed research; C.M.C. and M.S.S. analyzed data; C.M.C. and M.S.S. wrote the paper.

This work was supported by the National Institutes of Health Grants R01 NS094461 and R01 NS043394 to M.S.S.; Presidential Scholar award to M.S.S., and a postdoctoral training fellowship to C.M.C. from Training Grant T32 HL007446 (James D. Stockand, PI). The authors wish to thank Isamar Sanchez and Maryann Hobbs for expert technical assistance with this project.
}

(SFA), bursting, and hyperexcitatory states (Cooper and Jan, 2003; Brown and Passmore, 2009; Gamper and Shapiro, 2015; Greene and Hoshi, 2017). M-channel function is modulated by metabotropic G-protein-coupled receptors, providing a powerful mechanism by which neuronal networks alter signaling functions. M-current $\left(I_{\mathrm{M}}\right)$ was named due to its depression by stimulation of $\mathrm{G}_{\mathrm{q} / 11}$-coupled muscarinic acetylcholine receptors (mAChRs) in sympathetic ganglia (Brown and Adams, 1980;

The authors declare no competing financial interests.

Correspondence should be addressed to Mark S. Shapiro at shapirom@uthscsa.edu.

https://doi.org/10.1523/JNEUROSCI.1781-18.2018

Copyright $@ 2019$ the authors $\quad 0270-6474 / 19 / 391566-22 \$ 15.00 / 0$ 
Constanti and Brown, 1981), where the principal mechanism of action is hydrolysis and depletion of phosphatidylinositol 4,5bisphosphate $\left(\mathrm{PIP}_{2}\right)$ by phosphalipase $\mathrm{C} \beta$ (PLC) (Zhang et al., 2003; Suh and Hille, 2007). Stimulation of other $G_{q / 11}$-coupled receptors also depresses $I_{\mathrm{M}}$, but involves second messengers such as $\mathrm{Ca}^{2+}$ /calmodulin without depletion of $\mathrm{PIP}_{2}$ (Gamper et al., 2003; Bal et al., 2010; Kosenko and Hoshi, 2013), as well as $\mathrm{Ca}^{2+}{ }_{\mathrm{i}}{ }^{-}$ driven stimulation of $\mathrm{PIP}_{2}$ synthesis, a pathway long well described in nonexcitable cells (Tuosto et al., 2015). Similar pleiotropic signaling has been shown in heart, governing multimodal regulation of the G-protein-activated inward-rectifier $\mathrm{K}^{+}$ (GIRK-type, Kir3) channels, which are under tight control by $\mathrm{PIP}_{2}$ in cardiac cells and neurons (Logothetis et al., 2015).

Regulation of excitability and circuit behavior has been thoroughly studied in the hippocampus due to its fundamental roles in learning, memory, and cognition (Nicoll, 2017) and abnormally in epilepsy (Poolos and Johnston, 2012; Takano and Coulter, 2012; Dengler et al., 2017). The dentate gyrus (DG) filters external afferent inputs into the hippocampal circuit as a "gatekeeper" of excitability, which is crucial to the processing of physiological (Coulter and Carlson, 2007, Madroñal et al., 2016) and pathophysiological network functions (Krook-Magnuson et al., 2015). Because DG granule cells (DGGCs) are typically quiescent at rest, robust excitatory signaling at these neurons dramatically increases the activity of the hippocampus (Lübke et al., 1998; Kobayashi and Buckmaster, 2003; Hester and Danzer, 2013; Scharfman and Myers, 2016). $I_{M}$ activity strongly modulates DG excitability, inherent in afterhyperpolarization and spike-frequency adaptation (SFA) (Peters et al., 2005; Singh et al., 2008; Tzingounis and Nicoll, 2008; Petrovic et al., 2012; Soh et al., 2014). The hippocampus is strongly innervated by cholinergic inputs from the medial septum/diagonal band of the basal forebrain (Nyakas et al., 1987; Sotty et al., 2003) and $\mathrm{M}_{1}$ Rs are abundant in neurons of the hippocampus (Levey et al., 1995; Volpicelli and Levey, 2004). The cholinergic/M-channel axis represents a significant mechanism of control of DGGC excitability (Martinello et al., 2015). Moreover, long-term plasticity and ion channel dysregulation during mAChR stimulation may have consequences on the inhibitory function of $I_{\mathrm{M}}$ in DG and hippocampus. Significant increase to transcription of KCNQ2/3 mRNA in the hippocampus after chemoconvulsant-induced seizures suggests long-term linkage of temporal-lobe states of excitability with M-channel expression and regulation (Zhang and Shapiro, 2012). Loss-of-function mutations in M channels underlie inherited epilepsy disorders (Singh et al., 1998; Biervert al., 1998 ) and KCNQ2 or KCNQ3 channel suppression in mice generates epileptic phenotypes (Peters et al., 2005; Singh et al., 2008).

In this study, we sought to elucidate the actions of mAChR stimulation on $I_{\mathrm{M}}$ and delineate the intracellular signaling mechanisms underlying effects on threshold $\mathrm{K}^{+}$currents in the hippocampus. Using brain-slice electrophysiology and $\mathrm{Ca}^{2+}$ imaging, we unexpectedly found highly disparate mechanisms regulating excitability between DGGC and CA1 pyramidal neurons. Astonishingly, $I_{M}$ was strongly enhanced by stimulation of $\mathrm{G}_{\mathrm{q} / 11^{-}}$coupled mAChRs in DGGCs, as was $I_{\text {GIRK }}$ in parallel. Paradoxically, stimulation of mAChRs also increased excitability. We delineate the mechanisms of such phenomena as being via $\mathrm{Ca}^{2+}{ }_{\mathrm{i}^{-}}$ mediated stimulation of $\mathrm{PIP}_{2}$ synthesis upon muscarinic stimulation coupled with simultaneous activation of TRPC (transient receptor potential, "canonical") cation channels by PLC. Whereas the net effect of muscarinic stimulation in DGGCs is markedly increased excitability, this is due to synergy between $\mathrm{G}_{\mathrm{q} / 11}$-driven signals involving two opposing ion channels, $\mathrm{Ca}^{2+}$ rises from multiple sources and regulation of lipid metabolism. These novel findings reveal intricate but pleiotropic signaling systems in the hippocampus and perhaps elsewhere in the brain, in which input/output coupling of neuron circuitry is crucial to cerebral function and to halting adverse spread of hyperexcitability that, among other events, promotes seizures.

\section{Materials and Methods}

Animals. Wild-type (WT) adult male C57BL/6 mice (RRID:IMSR_JAX: 000664) between 2 and 4 months of age were used for the electrophysiology experiments in this study. Muscarinic receptor 1 knock-out (M1 KO) mice were also used (Hamilton et al., 1997) and were kindly provided initially by Jurgen Wess (National Institutes of Health). Muscarinic DREADD (Designer Receptors Exclusively Activated by Designer Drug) mice were generated by crossing hMDq-mCitrine (Tg(CAG-CHRM3 ${ }^{*}$,mCitrine)1Ute/J, Alexander et al., 2009; The Jackson Laboratory, RRID:IMSR_JAX:026220) mice with Cre-POMC mice (Tg(Pomc1cre)16Lowl/J; The Jackson Laboratory, RRID:IMSR_JAX:010714) for DGGC-specific expression (McHugh et al., 2007). KCNQ2 flox/flox mice were acquired as a kind gift from Anastasios Tzingounis (University of Connecticut). All mice were housed in an environmentally controlled animal facility with a $12 \mathrm{~h}$ light/dark cycle and had access to food and water ad libitum. Animals were cared for in compliance with the guidelines in the National Institutes of Health's Guide for Care and Use of Laboratory Animals. All animal procedures were performed in a protocol approved by the Institutional Animal Care and Use Committee of UT Health SA.

Hippocampal slice preparation. Transverse slices $(300 \mu \mathrm{m})$ of hippocampus were cut with a vibratome (Thermo Scientific, Microm HM650V) from mice using standard techniques with minor modifications, as reported previously (Carver et al., 2014). Mice were anesthetized with isoflurane and brains excised and placed in artificial CSF (ACSF) at $3.5^{\circ} \mathrm{C}$ composed of the following (in mM): $126 \mathrm{NaCl}, 3 \mathrm{KCl}, 0.5 \mathrm{CaCl}_{2}, 5$ $\mathrm{MgCl}_{2}, 26 \mathrm{NaHCO}_{3}, 1.25 \mathrm{NaH}_{2} \mathrm{PO}_{4}, 15$ glucose, and 0.3 kynurenic acid, with $\mathrm{pH}$ adjusted to $7.35-7.40$, with $95 \% \mathrm{O}_{2}-5 \% \mathrm{CO}_{2}, 305-315 \mathrm{mOsm} /$ $\mathrm{kg}$. Hippocampal slices were maintained in oxygenated ACSF at $30^{\circ} \mathrm{C}$ for $60 \mathrm{~min}$ and experiments were performed at $25^{\circ} \mathrm{C}$.

Patch-clamp electrophysiology. Patch pipettes were pulled from borosilicate glass capillaries (KG-33) using a Flaming/Brown micropipette puller P97 (Sutter Instruments) and had resistances between 5 and $7 \mathrm{M} \Omega$. The internal pipette solution consisted of the following (in $\mathrm{mm}$ ): $110 \mathrm{KCl}$, 2 EGTA, $2 \mathrm{MgCl}_{2}, 10$ HEPES, $4 \mathrm{Na}_{2}$-ATP, $2 \mathrm{Na}_{2}$-GTP, 10 Tris 2 phosphocreatine, and 10 tetrapotassium pyrophosphate adjusted to $7.3 \mathrm{pH}$ using $\mathrm{KOH}$ at $280 \mathrm{mOsm}$. In some recordings, a $10 \mu \mathrm{M}$ concentration of the cell-impermeant $\mathrm{Ca}^{2+}$ indicator calcium green-1 hexapotassium salt (Invitrogen) was added to the internal pipette solution to obtain simultaneous imaging/electrophysiology experiments. Electrophysiological recordings in the slice were performed in the whole-cell patch-clamp configuration. Neurons were visually identified with a Nikon FN-1 microscope equipped with a $40 \times$ water-immersion objective and infrared differential interference contrast optics and camera. Contrast dye loaded into the pipette was used to routinely confirm intact dendrites and axons of the neurons. Neurons without visible axons or with shortly-cut axons or were not examined. Current and voltage recordings were acquired using a HEKA EPC-9 amplifier and Pulse software (HEKA/Instrutech). Membrane capacitance, series resistance, and input resistance were monitored by applying $5 \mathrm{mV}$ depolarizing voltage steps. Drugs were delivered to the bath chamber using a multichannel perfusion system. All solutions were continuously bubbled with $95 \% \mathrm{O}_{2} / 5 \% \mathrm{CO}_{2}$.

Voltage-clamp protocol. For voltage-clamp recordings, DGGCs were held at $-75 \mathrm{mV}$ and CA1 pyramidal cells were held at $-65 \mathrm{mV}$. Wholecell current signals were digitized at $5-10 \mathrm{kHz}$ and filtered at $2 \mathrm{kHz}$. The bath recording solution consisted of the following (in $\mathrm{mM}$ ): $124 \mathrm{NaCl}, 3$ $\mathrm{KCl}, 1.5 \mathrm{MgCl}_{2}, 2.4 \mathrm{CaCl}_{2}, 1.25 \mathrm{Na}_{2} \mathrm{H}_{2} \mathrm{PO}_{4}, 26 \mathrm{NaHCO}_{3}$, and 15 glucose, adjusted to $7.4 \mathrm{pH}$ and $295-305 \mathrm{mOsm}$. When adding tetraethylammonium (TEA)-chloride to the external bath solution, it replaced an equivalent amount of $\mathrm{NaCl}$ to maintain proper osmolarity. The $\mathrm{Na}^{+}$channel blocker tetrodotoxin (TTX, $1.0 \mu \mathrm{M}$ ) was added to the bath during 
voltage-clamp recordings. $\mathrm{M}$ currents were studied in hippocampal neurons with pipette access resistances that averaged $\sim 16 \mathrm{M} \Omega$ under wholecell mode. Mature granule cells selected for analysis exhibited input resistances of $350-450 \mathrm{M} \Omega$. For $\mathrm{M}$-current recordings, the potential was held at $-25 \mathrm{mV}$, followed by $600 \mathrm{~ms}$ hyperpolarizing steps decrementing from -30 to $-80 \mathrm{mV}$. M-current amplitude was measured at $-55 \mathrm{mV}$ (the maximum amplitude of the deactivating current) as the $\sim 100 \mathrm{~ms}$ relaxation of the deactivating current sensitive to the $\mathrm{M}$-channel specific blocker XE-991 (20 $\mu \mathrm{M})$ (Zaczek et al., 1998). E-4031, which binds to the intracellular domain of ERG channels, was routinely supplied both in the internal pipette solution and bath solution $(10 \mu \mathrm{M})$ to quantify the contribution of ERG channels to the deactivating currents (Cui and Strowbridge, 2018), so E-4031 block could only be quantified as population averages between control and E-4031-perfused neuron groups.

Due to the typical nonspherical shape of neurons in brain slices, series resistance compensation, such as that used in experiments of dissociated neurons is of limited use. The product of the series resistance (10-20 $\mathrm{M} \Omega$ ) multiplied by the prepulse current clamped at $-20 \mathrm{mV}(200-300$ $\mathrm{pA}$ ) yields an estimate of the whole-cell voltage error, which we estimate to average $2-6 \mathrm{mV}$. For pipette and bath solutions for which the major cations are $\mathrm{K}^{+}$and $\mathrm{Na}^{+}$, respectively, the junction potential error (which was not corrected) is typically between -2 and $-4 \mathrm{mV}$ (Bernheim et al., 1991). Therefore, the true voltage at which the deactivating relaxation was quantified was estimated to be between $-54 \mathrm{mV}$ and -60 $\mathrm{mV}$ for each cell, very near the voltage classically used to quantify $\mathrm{M}$ current in peripheral neurons (Beech et al., 1991). We found that using careful vibratome technique, but similar pipette solutions used previously (Gamper et al., 2003), except with the inclusion of phosphocreatine, allowed stable whole-cell recordings of $I_{\mathrm{M}}$ in cells with series resistances $<20 \mathrm{M} \Omega$ over a sufficient time period to allow examination of brain slice-perfused drug actions (Kim et al., 2016a,b). Either the general muscarinic receptor agonist oxotremorine methiodine $(\mathrm{N}, \mathrm{N}, \mathrm{N}-$ Trimethyl-4-(2-oxo-1-pyrolidinyl)-2-butyn-1-ammonium iodide, oxo-M) or 77-LH-28-1 (1-[3-(4-butylpiperidin-1-yl)propyl]-3,4-dihydroquinolin2 -one oxalate) were used as agonists of endogenous $M_{1}$ Rs. M-current sweeps were acquired every $10 \mathrm{~s}$ and currents quantified $5 \mathrm{~min}$ after the start of bath-application of ACSF to the slice. In control experiments, we estimate the time required to perfuse the slice from initiation of bath-application to be $\sim 1 \mathrm{~min}$.

Current-clamp protocol. To derive active discharge properties of neurons, holding current was injected to maintain a membrane potential of $-75 \mathrm{mV}$ and square waves of current added in $+20 \mathrm{mV}$ steps for $500 \mathrm{~ms}$ with $10 \mathrm{~s}$ between each step up to a maximum of $300 \mathrm{pA}$. The individual properties of action potential waveforms were analyzed using AxoGraph and in-house software. Action potentials were detected with a derivative threshold of $20 \mathrm{mV} / \mathrm{ms}$. Ten to $90 \%$ peak rise times were calculated and action potential width measured at $10 \%$ of the peak. Afterhyperpolarization (AHP) amplitudes were measured as the maximum negative trough following an action potential minus the threshold of action potential initiation.

$\mathrm{Ca}^{2+}$ imaging. Concurrent with patch-clamp electrophysiology, neurons in slices were also imaged (Nikon FN-1, 40× water-immersion objective) via the fluorescent $\mathrm{Ca}^{2+}$-reporter dye calcium green-1. As a hexapotassium salt, the dye $(10 \mu \mathrm{M})$ was added to the intracellular patch pipette solution and neurons were patched under whole-cell clamp, as described above. Cells were loaded for $10 \mathrm{~min}$ before image acquisition. Fluorescence intensity was obtained using a SOLA Light Engine illumination source (Lumencor) with an output of $3.5 \mathrm{~W}$ through a $3-\mathrm{mm}$ diameter liquid light guide through a Nikon ET-GFP filter. Nikon Elements software was used for image acquisition through a QIClick CCD camera (QImaging). Images were acquired with an exposure time of $200 \mathrm{~ms}$ every 2 min using a single-channel, 12-bit rate and no binning. The shutter was closed between each acquisition. For each cell, the corrected total cell fluorescence was measured as the integrated density intensity - (cell area ${ }^{\star}$ mean background emission). $\mathrm{Ca}^{2+}$ signals were measured as the change in fluorescence relative to the baseline fluorescence $\left(\Delta F / F_{0}\right)$. Averages of four images were thresholded at $10 \%$, masked using a highly averaged image of the cell, and encoded with a pseudocolor look-up table. Group cell fluorescence data were averaged in comparison with normalized intensity at each time point.

Behavioral seizure studies. The muscarinic agonist pilocarpine was used to induce seizures in vivo. Two-month-old mice were injected with scopolamine methylnitrate $(1 \mathrm{mg} / \mathrm{kg}$; MP Biomedicals) to block peripheral mAChRs $30 \mathrm{~min}$ before administration of pilocarpine hydrochloride (280 mg/kg; Sigma-Aldrich). Drugs were delivered via intraperitoneal injection in $0.9 \%$ sterile saline at a total volume equivalent to $1 \%$ of the mouse body weight. Control mice were given the same dose of scopolamine followed by vehicle saline $30 \mathrm{~min}$ later. Mice were observed for $2 \mathrm{~h}$ and all seizure activity was visualized and scored in severity according to the modified Racine scale for mice (Racine, 1972). Within 15 min, mice exhibited continuous tremor activity and tail rigidity. Peak seizure activity was observed $60 \mathrm{~min}$ after pilocarpine delivery with occasional forelimb clonus.

Immunohistochemistry. KCNQ2 and KCNQ3 channels were visualized via immunohistochemistry of brain slices of $40-100 \mu \mathrm{m}$ thickness, cut with a vibratome, and fixed with methanol for $10 \mathrm{~min}$. Although we and others have found that such slices fixed with paraformaldehyde are not reliable for KCNQ channel detection, so unfixed brain slices were used in the past (Cooper et al., 2001; Pan et al., 2006; Klinger et al., 2011), our control experiments and others (Battefeld et al., 2014) indicate that slices fixed in methanol allow reliable immunodetection of KCNQ2 and KCNQ3 proteins. Free-floating slices were blocked with 8\% donkey serum and $0.2 \%$ Triton-X in PBS for $1 \mathrm{~h}$. Rabbit $\alpha$-KCNQ2 antibody (RRID:AB_2314688) and guinea pig $\alpha$-KCNQ3 antibody (RRID: AB_2314689) were kindly supplied by Ed Cooper (Baylor College of Medicine). Experiments probing with antibodies rabbit $\alpha$-muscarinic receptor type 1 (Millipore, RRID:AB_91713), goat $\alpha$-PROX1 (R\&D Systems, RRID:AB_2170716), and mouse $\alpha$-HA(12CA5) (Roche Diagnostics, RRID:AB_514505) were also conducted. Slices were incubated in a 1:1000 primary antibody dilution for $12 \mathrm{~h}$ at room temperature. After $3 \times$ PBS washes for $5 \mathrm{~min}$, donkey $\alpha$-rabbit rhodamine red and donkey $\alpha$-guinea pig FITC secondary IgG affinipurified antibodies (Jackson ImmunoResearch) were applied 1:250 for $2 \mathrm{~h}$ at room temperature. Sections were mounted with Vectashield reagent (Vector Laboratories) and imaged using a Nikon Eclipse FN1 swept-field confocal upright microscope. Images were obtained at a fixed exposure of $500 \mathrm{~ms}$ and a gain of 270 in a $10 \mathrm{MHz}$, 14-bit readout mode using an Andor iXon3 DU-897 EMCCD camera. FITC and TRITC excitation were performed at $80 \%$ laser power using 488 and $561 \mathrm{~nm}$ laser laser lines (MIC 400B; Agilent Technologies). KCNQ channel expression is represented as the mean \pm SEM of the ratio of the emissions from 488 and $561 \mathrm{~nm}$ excitation.

Drugs. Chemicals used in electrophysiology experiments were from Sigma-Aldrich unless otherwise specified. XE-991 and xestospongin C were from Abcam. The $\mathrm{M}_{1} \mathrm{R}$-specific allosteric agonist 77-LH-28-1 was from Aobious. Kynurenic acid, E-4031, ICA-069673, ZD7288, ML204, and M084 were from Tocris Bioscience. Retigabine dihydrochloride was from AdooQ Bioscience.

Experimental design and statistical analysis. Group data are expressed as the mean \pm SEM. Each electrophysiology experimental group was acquired from cells of multiple mice. Statistical comparisons of parametric measures, including electrophysiology data, were performed using an independent two-tailed Student's $t$ test, followed by Tukey's HSD test post hoc. In all statistical tests, the criterion for statistical significance was $p<0.05$ unless otherwise specified.

\section{Results}

\section{$M$ channels and ERG channels have differential fractional contributions to the threshold $\mathrm{K}^{+}$current of DGGCs and CA1 pyramidal neurons}

Hippocampal neurons express multiple classes of slowly deactivating, voltage-gated $\mathrm{K}^{+}$channels including $\mathrm{M}$ channels (KCNQ2/3) and ERG channels $\left(\mathrm{KCNH} 2, \mathrm{~K}_{\mathrm{v}} 11.1\right)$ that activate at potentials near threshold and contribute to regulation of neuronal discharge properties (Saganich et al., 2001; Hu et al., 2002; Jan and Jan, 2012; Mateos-Aparicio et al., 2014; Kim et al., 2016a,b). To determine the contribution of $I_{M}$ in hippocampal principal 


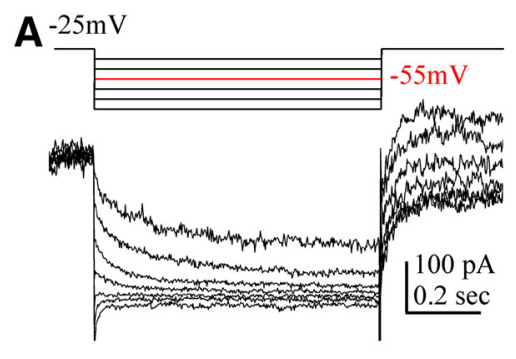

D

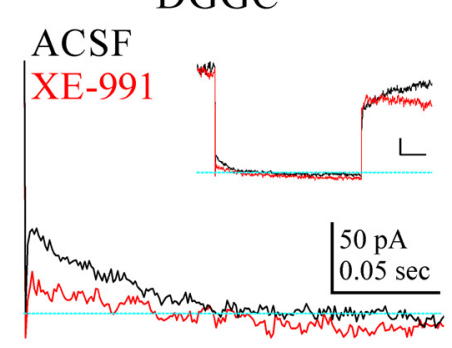

G
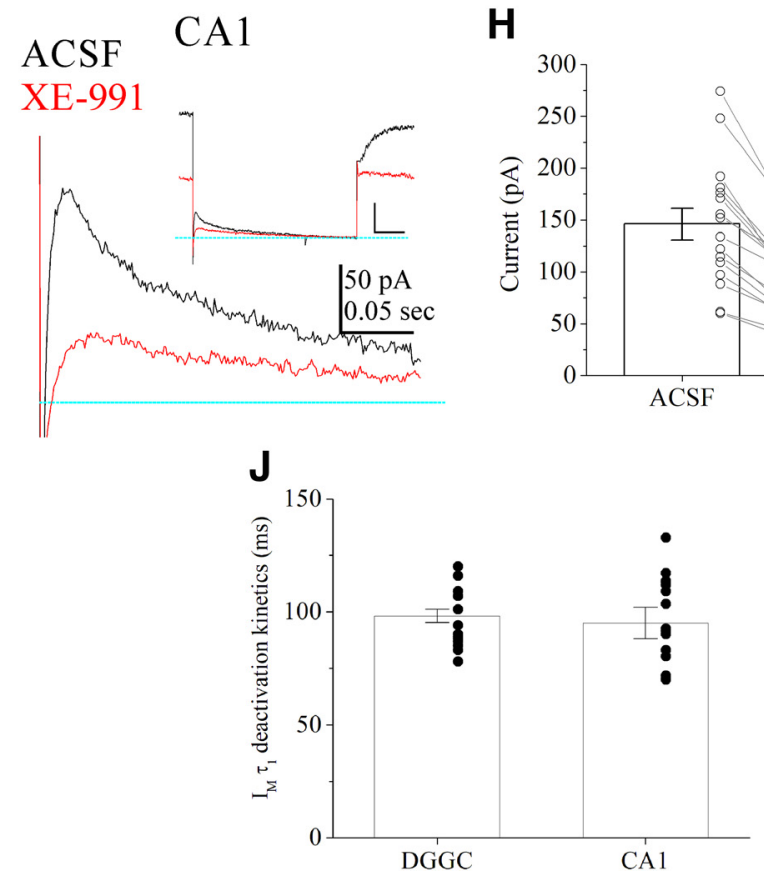

B

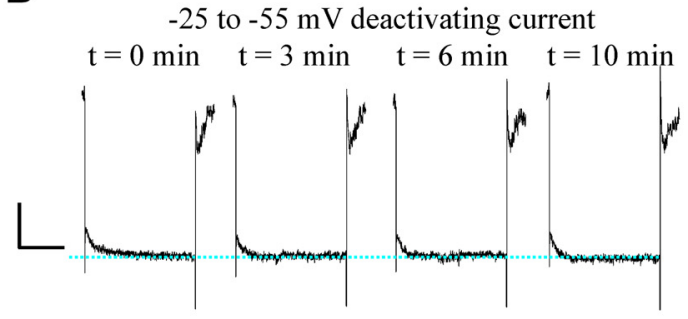

C

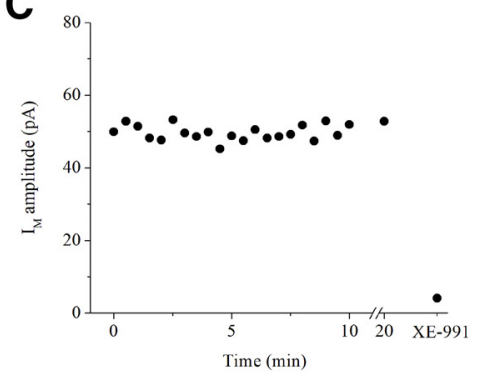

E

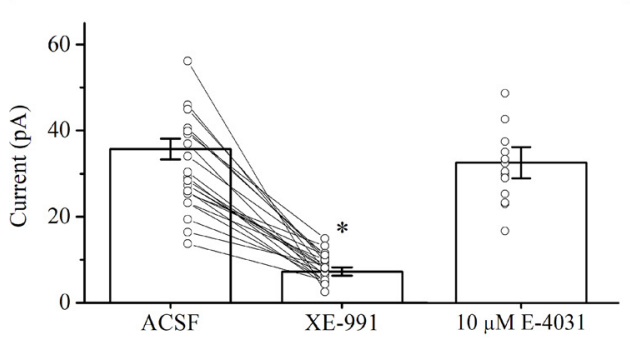

H

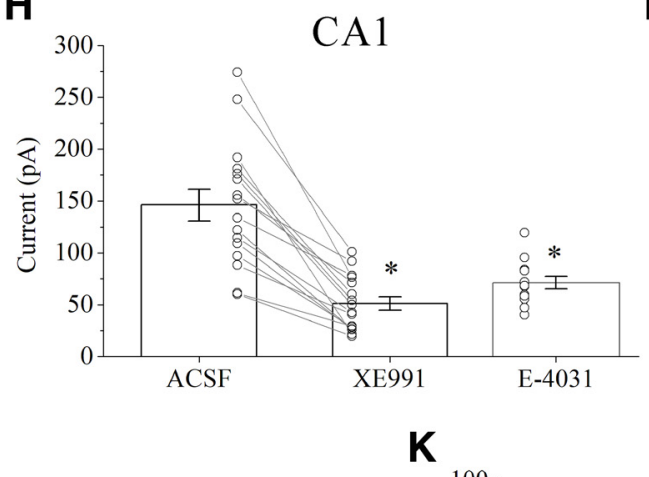

K
F

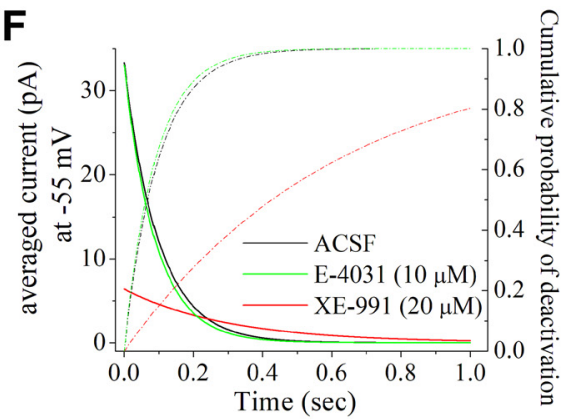

I

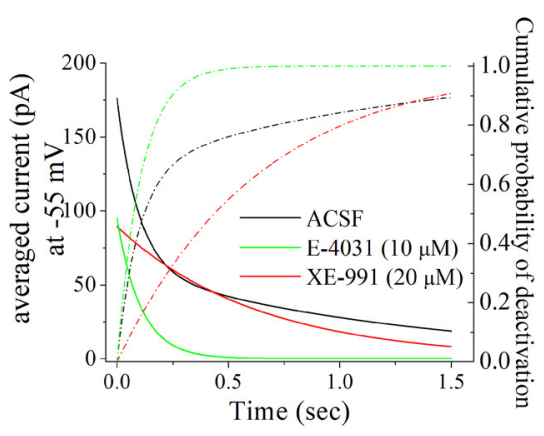

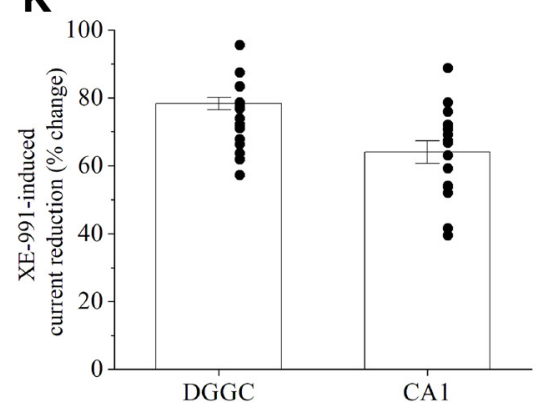

Figure 1. Contribution of $I_{M}$ and $\mathrm{I}_{\mathrm{ERG}}$ to the threshold $\mathrm{K}^{+}$conductances of $\mathrm{DGGCs}$ and $\mathrm{CA} 1$ pyramidal cells under brain-slice voltage-clamp conditions. $A$, Hyperpolarizing $10 \mathrm{mV}$ steps of currents from a DGGC under whole-cell voltage-clamp conditions using the protocol shown in the inset. $\boldsymbol{B}, \mathrm{DGGC}$ voltage-clamp recordings of deactivating currents from $-25 \mathrm{mV}$ to $-55 \mathrm{mV}$, with only $\mathrm{ACSF}$ bath-application over the indicated time. Scale bars, $100 \mathrm{pA}, 0.4 \mathrm{~s}$. C, Summarized time courses of current amplitude from the neuron recorded in $\boldsymbol{B}$, with sweeps taken every $30 \mathrm{~s}$. XE- 991 (20 $\mu \mathrm{M}$ ) significantly reduced the deactivating current. $\boldsymbol{D}$, Representative expanded current traces at $-55 \mathrm{mV}$, of full current traces shown in the inset, from a DGGC bathed in control ACSF, or when XE991 $(20 \mu \mathrm{M})$ was added to the bath. Inset scale bars: $50 \mathrm{pA}, 500 \mathrm{~ms}$. E, Bars summarize amplitudes of the deactivating current relaxation at $-55 \mathrm{mV}$ in control solution (ACSF) or when XE-991 (20 $\mu \mathrm{m}$ ) or E-4031 $(10 \mu \mathrm{M})$ was added to the bath. $n=20-22$ cells. ${ }^{*} p<0.05$ vs ACSF. $F$, Averaged current relaxations as in $D$ in control ACSF or in the presence of XE-991 (20 $\left.\mu \mathrm{M}\right)$ or E4031 (10 $\left.\mu \mathrm{M}\right)$. The ordinates are normalized current (left) or cumulative probability of decay (right). The averaged currents in the presence of either blocker were fit by a single exponential relation. $G$, Expanded views of representative deactivating currents from the step from $-25 \mathrm{mV}$ to $-55 \mathrm{mV}$ step from a CA1 pyramidal cell. The inset shows the full current traces. Inset scale bar: $200 \mathrm{pA}, 0.2 \mathrm{~s}$. $\boldsymbol{H}, \mathrm{Bars}$ summarize the amplitudes of the deactivation currents from CA1 neurons in control (ACSF) or in the presence or XE-991 (20 $\mu \mathrm{m})$ or E-4031 (10 mM); $n=16$ cells. ${ }^{*} p<0.05$ versus ACSF.I, Averaged deactivation currents from CA1 neurons as in $\boldsymbol{F}$. The total current was well fit by a double exponential for which $I_{M}$ (XE-991-sensitive) contributed to the $\tau_{1}$ and $I_{\text {ERG }}$ channels (E-4031-sensitive) contributed to the $\tau_{2}$.J, Summary of $\tau_{1}$ deactivation current kinetics between DGGCs and CA1 neurons from $\boldsymbol{F}$ and $\boldsymbol{I}$. $\boldsymbol{K}$, Summary of XE-991 sensitive $\boldsymbol{I}_{\mathbf{M}}$ current between DGGCS and CA1 as in $\boldsymbol{E}$ and $\boldsymbol{H}$.

neurons, we examined the deactivating current relaxation at a range of voltages $-85 \mathrm{mV}$ to $-35 \mathrm{mV}$ (see Materials and Methods) from a holding potential of $-25 \mathrm{mV}$, at which voltages most other $\mathrm{K}^{+}$conductances fully inactivate (Fig. $1 A$ ). The deactivating current amplitudes and kinetics were examined under wholecell voltage-clamp electrophysiology in brain slices. In ACSF recording conditions, $I_{\mathrm{M}}$ amplitude persisted stably for $>10 \mathrm{~min}$ and negligible run-down of $I_{\mathrm{M}}$ was observed (Fig. $1 \mathrm{~B}, \mathrm{C}$ ), suggesting an abundant and stable available pool of $\mathrm{PIP}_{2}$ or other necessary cytoplasmic molecules. The addition of lipid-kinase substrates such as myo-inositol, which could compromise our experiments, was not required. Likewise, inclusion of $\mathrm{Na}^{+}$or- 
thovanadate $(0.1 \mathrm{~mm})$ or pyrophosphate $(10 \mathrm{~mm})$ in the pipette solution to inhibit $\mathrm{PIP}_{2}$ phosphatase activity (Huang et al., 1998) did not significantly alter tonic deactivating current amplitudes nor affect their stability (control: $33.4 \pm 1.9 \mathrm{pA}$, with VPP: $38.3 \pm$ $5.2 \mathrm{pA} ; n=12-20$ cells per group, $t_{(30)}=1.05, p=0.3$ ).

In WT DGGCs, the fraction of current blocked by a saturating concentration of $20 \mu \mathrm{M} \mathrm{XE-991} \mathrm{(here} \mathrm{referred} \mathrm{to} \mathrm{as} I_{\mathrm{M}}$ ) had a current density of $3.60 \pm 0.3 \mathrm{pA} / \mathrm{pF}$ (Fig. $1 D-F$ ). Deactivating currents were well fit by a single exponential with a time constant $\tau=98 \pm 3 \mathrm{~ms}$ ( $n=15$ cells $)$, which closely corresponds to the kinetics found previously in sympathetic neurons and in hippocampus (Beech et al., 1991; Gamper et al., 2003; Lawrence et al., 2006a). The total current density was $4.42 \pm 0.32 \mathrm{pA} / \mathrm{pF}$ and the residual current density was significantly reduced to $0.90 \pm$ $0.08 \mathrm{pA} / \mathrm{pF}$ after addition of XE-991, indicating that $78.3 \pm 1.8 \%$ of the total deactivating current was due to $I_{\mathrm{M}}\left(t_{(54)}=10.6, p<\right.$ 0.0001 ), with the rest displaying much slower kinetics (Fig. $1 E, F)$. This residual current was also well fit by a single exponential, with a time constant $>5$-fold slower $(0.6 \pm 0.08 \mathrm{~s})$. The pharmacological data are summarized in Figure $1 E$, which also give an indication of the variation in block of the relaxation current after XE-991 in these experiments. In patch-clamp experiments on dissociated peripheral ganglia neurons or on tissueculture cells heterologously expressing KCNQ2-4 channels, complete block of current is routinely achieved by XE-991 at $10 \mu \mathrm{M}$ (Shapiro et al., 2000; Zhang et al., 2011); however, the multicell diffusion barrier inherent in brain-slice electrophysiology makes such assumptions difficult. As in previous slice work, to determine fractional $I_{\mathrm{M}}$ (Battefeld et al., 2014; Kim et al., 2016a,b; Niday et al., 2017), we can estimate the fraction to be very large in DGGCs. Therefore, we define the total XE-991sensitive current as the fractional current of KCNQ2/3 channels contributing to $I_{\mathrm{M}}$ (Kim et al., 2016a,b). Although the residual current displayed slower deactivation kinetics that might presume involvement of ERG channels (Wang et al., 1998; Gustina and Trudeau, 2009; Larsen, 2010), addition of the ERG channel blocker E-4031 $(10 \mu \mathrm{M})$ to the bath and internal pipette solutions did not significantly alter that current amplitude $\left(t_{(28)}=0.6, p=\right.$ $0.55)$ nor the deactivation currents $\left(t_{(28)}=0.98, p=0.65, n=15\right.$ cells) in DGGCs (Fig. $1 E, F$ ), perhaps suggesting another member of the EAG channel family that is insensitive to E-4031, such as Elk2 (KCNH3/K 12.2 ) (Saganich et al., 2001; Gessner and Heinemann, 2003).

In CA1 pyramidal neurons, $I_{\mathrm{M}}$ plays a variety of roles in determining active and passive discharge properties, including intrinsic excitability, SFA, bursting behavior, synaptic integration, and resonance (Yue and Yaari, 2004, 2006; Gu et al., 2005; Hu et al., 2007; Tzingounis and Nicoll, 2008; Leão et al., 2009; Fidzinski et al., 2015). As a result, M-channels in CA1 neurons contribute heavily to regulation of neurotransmitter release and synaptic plasticity (Vervaeke et al., 2006; Petrovic et al., 2012) and as a brake to hyperexcitability (Otto et al., 2002). EAG family $(\mathrm{KCNH})$ channels are also expressed in CA1 neurons (Saganich et al., 2001), which are likely responsible for part of the threshold $\mathrm{K}^{+}$current (Cui and Strowbridge, 2018). We performed parallel experiments in CA1 pyramidal neurons in the testing of threshold $\mathrm{K}^{+}$currents under whole-cell voltage-clamp condiditons (Fig. $1 G, H$ ). The amplitude of the total deactivating current in CA1 was much larger than in DGGCs. In addition, the fraction due to $I_{\mathrm{M}}$ was less, consistent with previous reports of multiple types of threshold $\mathrm{K}^{+}$currents present in CA1 neurons (Saganich et al., 2001; Shah et al., 2008; Klinger et al., 2011; Fano et al., 2012; Zhou et al., 2013). The total deactivating current density was
$14.5 \pm 1.2 \mathrm{pA} / \mathrm{pF}$ and current ascribed to $I_{\mathrm{M}}$ by XE-991 block $(20 \mu \mathrm{M})$ was $9.5 \pm 1.1 \mathrm{pA} / \mathrm{pF}\left(t_{(30)}=3.07, p=0.0045\right.$; Fig. $\left.1 H\right)$. This corresponds to $I_{\mathrm{M}}$ accounting for $64.0 \pm 3.3 \%$ of the total deactivating current amplitude, which averaged $51 \pm 7 \mathrm{pA}$. In a separate population of cells, inclusion of E-4031 $(10 \mu \mathrm{M})$ in the bath and pipette solutions reduced the average deactivating current amplitude to $7.9 \pm 0.4 \mathrm{pA} / \mathrm{pF}\left(t_{(20)}=3.29, p=0.0036\right.$; Fig. $1 H)$. Deactivating current kinetics in CA1 neurons were best fit with a biexponential function, with values of $95 \pm 7 \mathrm{~ms}$ and $1.25 \pm 0.25 \mathrm{~s}$ for $\tau_{1}$ and $\tau_{2}$, respectively (Fig. $1 I$ ). The $\tau_{1}$ exponent was eliminated after application of XE-991, but as for DGGCs, a relaxation with much slower kinetics remained. However, in CA1 neurons, E-4031 effectively eliminated the slow $\tau_{2}$ component of the relaxation, whereas the fast $\tau_{1}$ component remained unaltered (Fig. 1I). These results reinforce earlier studies suggesting the partial contribution of the threshold $\mathrm{K}^{+}$current in CA1 pyramidal neurons to be from ERG channels. The faster $\tau_{1}$ component of the current relaxation in CA1 neurons was indistinguishable from the single-exponent $\tau$ determined for the relaxation current in DGGCs (Fig. $1 J$ ). We conclude that approximately two-thirds of the deactivating current in CA1 pyramidal neurons is due to $I_{\mathrm{M}}$ and the remainder mostly due to $I_{\mathrm{ERG}}$; therefore, both conductances in these neurons contribute to the threshold $\mathrm{K}^{+}$current (Fig. $1 K$ ).

$\mathrm{G}_{\mathrm{q} / 11}$-coupled muscarinic receptor stimulation enhances $I_{M}$ in DGGCs, but suppresses $I_{M}$ in CA1 pyramidal neurons

Through comparative examination of DGGCs and CA1 pyramidal neurons, the nature of $\mathrm{G}_{\mathrm{q} / 11}$-coupled $\mathrm{mAChR}$ action on the threshold $\mathrm{K}^{+}$channels was examined. We focused on the modulation of $I_{\mathrm{M}}$, and on the signal transduction mechanisms involved. As above, neurons were studied under whole-cell brain-slice voltage-clamp conditions. From the robust literature documenting $\mathrm{M}_{1} \mathrm{R}$-mediated depression of $I_{\mathrm{M}}$ in multiple types of peripheral neurons and the known increase in neuronal excitability in hippocampus and other brain regions resulting from mAChR stimulation (Bymaster et al., 2003; Shen et al., 2005; Sheffler et al., 2009; Chiang et al., 2010), we expected parallel results from DGGCs and CA1 neurons. However, this was not the case.

In DGGCs, bath-application of the nonselective mAChR agonist oxotremorine methiodide (oxo-M) enhanced $I_{\mathrm{M}}$, rather than suppressing it, in a concentration-dependent manner (Fig. $2 A-C)$. Maximal enhancement of $I_{\mathrm{M}}$ current density reached $2.43 \pm 0.25$-fold at $10 \mu \mathrm{M}$ oxo-M $(3.27 \pm 0.39$ vs $7.15 \pm 0.70$ $\mathrm{pA} / \mathrm{pF} ; t_{(40)}=4.84, p<0.0001, n=21$ cells $)$. Due to the unanticipated and astonishing nature of these results, we also tested the effects of alternative muscarinic agonists. The muscarinic agonist pilocarpine $(10 \mu \mathrm{M})$ also increased $I_{\mathrm{M}}$ in granule cells by $2.45 \pm 0.13$-fold $\left(3.8 \pm 0.6 \mathrm{pA} / \mathrm{pF}\right.$ vs $9.3 \pm 1.8 \mathrm{pA} / \mathrm{pF} ; t_{(6)}=2.90$, $p=0.03, n=4$ cells). Although unlikely, it is conceivable that such a result could be due to stimulation of $G_{i / o}$-coupled $M_{2} / M_{4}$ mAChRs via some unknown pathway. Therefore, we also tested the $\mathrm{M}_{1} \mathrm{R}$-specific allosteric agonist, 77-LH-28-1 (Langmead et al., 2008; Thomas et al., 2008). Bath-application of 77-LH-28-1 over a range of concentrations produced a similar increase of $I_{\mathrm{M}}$ in DGGCs, up to $2.41 \pm 0.21$-fold at $10 \mu \mathrm{M}$ (Fig. $2 D, E$ ). We performed similar experiments using $M_{1} R$ germline knock-out $\left(M_{1} \mathrm{KO}\right)$ mice (Hamilton et al., 1997) and DGGCs with $M_{1} R$ deletion did not exhibit a significant change in $I_{\mathrm{M}}$ amplitude by bath-application of 77-LH-28-1 (ACSF: $3.2 \pm 0.6 \mathrm{pA} / \mathrm{pF}$; 77-LH$28-1: 3.3 \pm 0.6 \mathrm{pA} / \mathrm{pF}, t_{(8)}=0.12, p=0.91, n=5$ cells $)$. Given previous findings of muscarinic suppression of $I_{M}$ in rat DG 

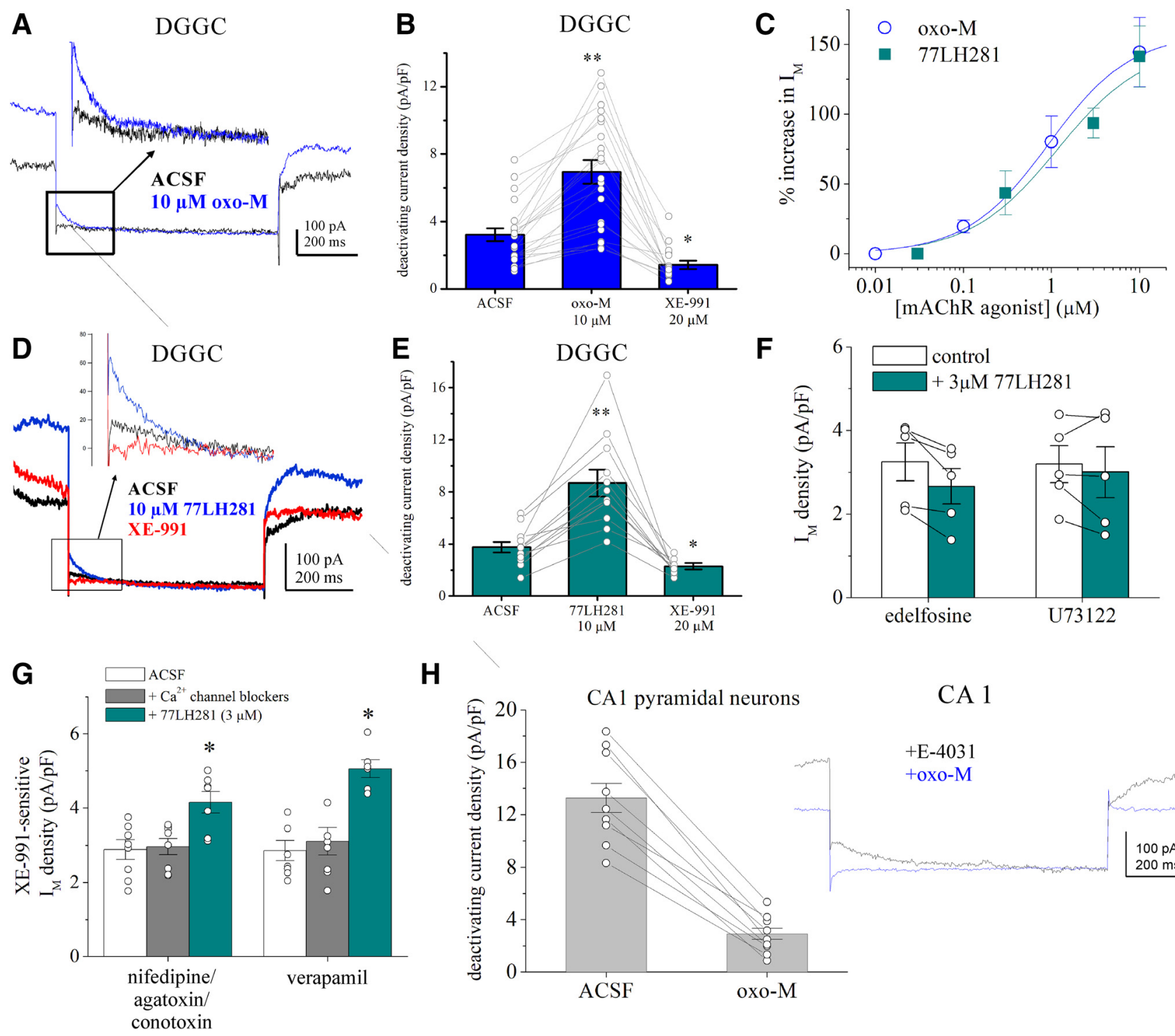

H

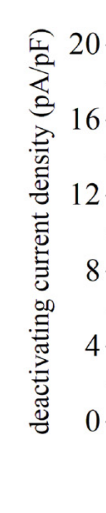

CA1 pyramidal neurons

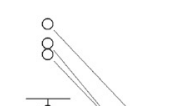

\section{CA 1}

Figure 2. Stimulation of $G_{q / 11}$-coupled muscarinic receptors enhances $I_{M}$ in DGGCs but suppresses $/ M$ in CA1 pyramidal cells. $A$, Superimposed traces of currents in control (ACSF) or in the presence of oxo-M $(10 \mu \mathrm{M})$ from a DGGC under whole-cell clamp. The deactivating relaxations are shown expanded in the inset. $B$, Bars summarize the deactivating current densities from DGGCs in control or in the presence of oxo-M (10 $\mu \mathrm{M})$ or XE-991 (20 $\mu \mathrm{M})$. C, Plotted is the enhancement of $I_{\mathrm{M}}$ amplitude as a function of oxo-M or 77-LH-28-1 concentrations. The data were fit by a Hill equation with parameters for $0 \times 0-\mathrm{M}\left(\mathrm{EC}_{50}: 0.92 \pm 0.36 \mu \mathrm{m}\right.$; coff $\left.=0.9 \pm 0.2\right)$ or $77-\mathrm{LH}-28-1\left(\mathrm{EC}_{50}: 1.18 \pm 0.38 \mu \mathrm{m} ; n=0.9 \pm 0.2\right)$. D, Superimposed traces of deactivating currents in control or in the presence of 77-LH-28-1 (10 $\mu \mathrm{m})$ or XE-991 (20 $\mu \mathrm{M})$. The deactivating relaxations are shown expanded in the inset. $\boldsymbol{E}$, Bars summarize the data for 77-LH-28-1 as in $\boldsymbol{D}$. $\boldsymbol{F}$, Bars summarize effect on $I_{\mathrm{M}}$ by bath-application of 77-LH-28-1 (3 $\mu \mathrm{M})$ in the presence of the PLC-blockers edelfosine or U73122. G, Bars summarize the effect of inclusion of Ca ${ }^{2+}$ channel blockers on $I_{M}$ in DGGC before and after

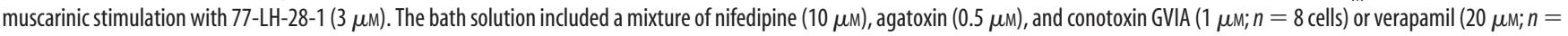
6 cells). In the presence of the mixture or verapamil, 77 -LH-28-1 induced $1.55 \pm 0.05$-fold or $1.83 \pm 0.10$-fold increases to $I_{M}$, respectively. $\boldsymbol{H}$, Summary of the effect of bath-application of oxo-M $(10 \mu \mathrm{M})$ on suppression of $I_{M}$ identified as the faster deactivating component of the current relaxation in CA1 pyramidal neurons. On the right are superimposed current traces in the presence of oxo-M or E-4031. * $p<0.05 ;{ }^{* *} p<0.001$.

(Martinello et al., 2015), we also performed similar electrophysiology experiments in adult rat DGGCs. Contrary to previous findings, $\mathrm{M}_{1} \mathrm{R}$ stimulation with 77-LH-28-1 (3 $\left.\mu \mathrm{M}\right)$ resulted in robust enhancement of $I_{\mathrm{M}}(1.80 \pm 0.28$ fold, $n=5$ cells $)$ in the rat slice preparation, similar to what we observed in the mouse (1.93 \pm 0.09 fold, as in Fig. 2). Together, these data confirm that the observed enhancement of $I_{\mathrm{M}}$ in DGGCs by mAChR stimulation is indeed driven by $\mathrm{G}_{\mathrm{q} / 11}$-coupled $\mathrm{M}_{1}$ Rs.

Given such novel and provocative results, we verified that enhancement of $I_{M}$ in DGGCs involved activation of PLC, as is usually the case with $\mathrm{G}_{\mathrm{q} / 11}$ actions. Preincubation of slices with the broad-spectrum PLC inhibitor, U73122, blocked any effect on $I_{\mathrm{M}}$ of muscarinic stimulation by 77-LH-28-1 (10 $\left.\mu \mathrm{M}\right)$ and did not significantly alter $I_{\mathrm{M}}$ amplitudes $\left(t_{(8)}=0.21, p=0.83, n=5\right.$ cells; Fig. $2 F$ ). However, because previous studies have demonstrated that U73122 induces a negative shift in the voltage dependence of activation of M-channels (Horowitz et al., 2005), we also tested the effects of edelfosine $(10 \mu \mathrm{M})$, a more specific inhibitor of PLC with no agonist activity or observed nonspecific effects on M-channel gating (Horowitz et al., 2005). Similar to U73122, incubation of slices with edelfosine completely abolished $\mathrm{M}_{1} \mathrm{R}$ stimulation-induced enhancement of $I_{\mathrm{M}}\left(t_{(8)}=0.94, p=0.38\right.$, $n=5$ cells; Fig. $2 F$ ). Furthermore, previous work has shown that sustained $\mathrm{Ca}^{2+}$ influx by voltage-gated $\mathrm{Ca}^{2+}$ channels can facilitate $I_{\mathrm{M}}$ by stimulating PKA activity in hippocampal neurons (Wu et al., 2008). To test whether the prepulse depolarization of 
DGGCs used in our voltage protocol provoked effects of $\mathrm{Ca}^{2+}$ currents through voltage-dependent $\mathrm{Ca}^{2+}$ channels on $\mathrm{M}_{1} \mathrm{R}$ mediated enhancement of $\mathrm{M}$ current, we tested the effects of voltage-gated $\mathrm{Ca}^{2+}$ channel blockers during $\mathrm{M}_{1} \mathrm{R}$ stimulation (Fig. $2 G)$. We bath-applied a mixture of nifedipine $(10 \mu \mathrm{M})$, $\omega$-agatoxin IVA $(0.5 \mu \mathrm{M})$, and $\omega$-conotoxin GVIA $(1 \mu \mathrm{M})$ to block L-type, P/Q-type, and N-type channels, respectively. There were no significant differences in the XE-991-sensitive $I_{\mathrm{M}}$ between ACSF $(2.9 \pm 0.3 \mathrm{pA} / \mathrm{pF})$ and in the presence of the $\mathrm{Ca}^{2+}$ channel-blocker mixture $\left(3.0 \pm 0.2 \mathrm{pA} / \mathrm{pF}, t_{(14)}=0.278, p=\right.$ 0.78). However, in the presence of the $\mathrm{Ca}^{2+}$ channel blockers, there was significant potentiation of $I_{\mathrm{M}}$ by 77-LH-28-1 (4.2 \pm 0.3 $\mathrm{pA} / \mathrm{pF}, t_{(14)}=3.32, p=0.004, n=8$ cells), resulting in a $1.55 \pm$ 0.05 -fold increase in the current. We also tested verapamil (20 $\mu \mathrm{M})$, which has high affinity for L-type and T-type channels at depolarized potentials (Bergson et al., 2011). Again, there were no significant differences of $I_{\mathrm{M}}$ comparing between control $(2.9 \pm 0.2 \mathrm{pA} / \mathrm{pF})$ and ACSF + verapamil $(3.1 \pm 0.4 \mathrm{pA} / \mathrm{pF}$; $\left.t_{(10)}=0.45, p=0.66\right)$, but 77-LH-28-1 application still significantly increased $I_{\mathrm{M}}$ in the presence of verapamil $(5.1 \pm 0.2 \mathrm{pA} / \mathrm{pF}$; $t_{(10)}=4.47, p=0.0012, n=6$ cells), resulting in a $1.8 \pm 0.1$-fold increase in $I_{\mathrm{M}}$. Therefore, voltage-gated $\mathrm{Ca}^{2+}$ channel blockade does not significantly alter the facilitation of $I_{\mathrm{M}}$ by stimulation of $\mathrm{M}_{1}$ Rs.

To determine whether the resulting potentiation that we observed was unique to DGGCs or is generalized throughout the hippocampus, we then investigated the effects of stimulation of $\mathrm{M}_{1}$ Rs on $I_{\mathrm{M}}$ in CA1 pyramidal neurons. In CA1, previous evidence has shown $I_{\mathrm{M}}$ to be suppressed in pyramidal neurons by muscarinic stimulation (Madison et al., 1987; Fiszman et al., 1991; Rouse et al., 2000). In parallel experiments to those performed on DGGCs, we assayed the effect of $\mathrm{M}_{1} \mathrm{R}$ stimulation of CA1 neurons under whole-cell brain-slice voltage-clamp conditions (Fig. $2 H)$. Bath-application of oxo-M $(10 \mu \mathrm{M})$ suppressed the deactivating current amplitude by $79.1 \pm 2.8 \%(n=10$ cells $)$, as defined by the faster deactivating $\tau_{1}$ of $\sim 100 \mathrm{~ms}$, similar to previous reports of $I_{\mathrm{M}}$ suppression in the slice (Rouse et al., 2000). In the presence of muscarinic agonists to CA1 neurons, there was a persistent $>1 \mathrm{~s}$ deactivating current, which was eliminated in the presence of $10 \mu \mathrm{M} \mathrm{E}-4031$. Similarly, bathapplication of 77-LH-28-1 to CA1 induced a suppression of $I_{\mathrm{M}}$ (oxo-M: $78.3 \pm 2.4 \%$; 77-LH-28-1: 81.6 $\pm 2.3 \%, n=5-7$ cells per group), confirming the involvement of $M_{1}$ Rs. XE-991 blocked the total deactivating current in CA1 neurons by $9.45 \pm$ $1.01 \mathrm{pA} / \mathrm{pF}$, leaving a residual current of $5.07 \pm 0.55 \mathrm{pA} / \mathrm{pF}$, whereas oxo-M application resulted in a $10.34 \pm 0.89 \mathrm{pA} / \mathrm{pF}$ suppression of the total deactivating current, leaving a residual current of $2.91 \pm 0.42 \mathrm{pA} / \mathrm{pF}$. Therefore, stimulation of $\mathrm{M}_{1} \mathrm{Rs}$ in CA1 pyramidal neurons profoundly suppresses $I_{\mathrm{M}}$ similar to the effect in peripheral ganglia. Therefore, the functional actions of $\mathrm{G}_{\mathrm{q} / 11}$-coupled $\mathrm{M}_{1}$ Rs on $\mathrm{M}$-channels are starkly divergent between DGGCs and CA1 pyramidal neurons.

\section{PIP $_{2}$ synthesis is strongly enhanced by stimulation of $\mathrm{G}_{\mathrm{q} / 11}$-coupled muscarinic receptors in DGGCs}

Because stimulation of $M_{1}$ Rs in DGGCs resulted in enhancement, rather than suppression of $I_{\mathrm{M}}$, we hypothesized an increase in PIP $_{2}$ abundance to be responsible for the increase in the current far above its tonic level. In a variety of tissues, stimulation of $\mathrm{G}_{\mathrm{q} / 11}$-coupled receptors stimulates $\mathrm{PIP}_{2}$ synthesis concurrently with PLC hydrolysis, driven by rises in $\left[\mathrm{Ca}^{2+}\right]_{i}$ (Lassing and Lindberg, 1990; Racaud-Sultan et al., 1993; Loew, 2007). Both physiological data in cerebellar neurons and biophysical model- ing (Finch and Augustine, 1998; Takechi et al., 1998; Brown et al., 2008 ) indicate that stimulation of $\mathrm{G}_{\mathrm{q} / 11}$-coupled receptors must increase $\mathrm{PIP}_{2}$ abundance in dendrite spine membrane by 2.5 -fold to account for accumulation of local intracellular $\mathrm{IP}_{3}$. In sympathetic neurons, subcellular microdomain organization precludes $\mathrm{M}_{1} \mathrm{R}$ stimulation from inducing $\mathrm{IP}_{3}$-mediated $\left[\mathrm{Ca}^{2+}\right]_{\mathrm{i}}$ rises, allowing substantial $\mathrm{PIP}_{2}$ depletion, whereas bradykinin $\mathrm{B}_{2} \mathrm{R}$ stimulation, for example, provokes sufficient rises in $\left[\mathrm{Ca}^{2+}\right]_{\mathrm{i}}$ and stimulation of $\mathrm{PIP}_{2}$ synthesis to compensate for any decrease in $\mathrm{PIP}_{2}$ abundance by PLC hydrolysis (Falkenburger et al., 2010). Whereas it is estimated that the abundance of PI in the plasma membrane of mammalian cells is $\sim 100,000$ molecules $/ \mu \mathrm{m}^{2}$, the tonic abundance of $\mathrm{PIP}_{2}$ is $\sim 1000-5000$ molecules $/ \mu \mathrm{m}^{2}$ (Xu and Loew, 2003; Xu et al., 2003; Suh et al., 2004; Winks et al., 2005; Hilgemann, 2007). At this tonic abundance of $\mathrm{PIP}_{2}$, a large body of work indicates $\mathrm{M}$ channels composed of KCNQ2/3 heteromers to be well under full saturation by $\mathrm{PIP}_{2}$ interactions (Suh et al., 2004; Hernandez et al., 2009; Falkenburger et al., 2010), consistent with a maximal open probability $P_{\mathrm{o}}$ of KCNQ2/3 heteromers of $\sim 0.3$, as experimentally measured at the single-channel level (Selyanko et al., 2001; Li et al., 2004). Indeed, this must be the case to make possible regulation of membrane proteins by $\mathrm{PIP}_{2}$ because, otherwise, physiological changes in either PIP $_{2}$ abundance or $\mathrm{PIP}_{2}$ affinity would have little effect (Hernandez et al., 2008a,b).

To test the hypothesis that stimulation of $\mathrm{PIP}_{2}$ synthesis occurs subsequent to $\mathrm{M}_{1} \mathrm{R}$ stimulation to DGGCs, we probed GIRK channels that have been demonstrated to require $\mathrm{PIP}_{2}$ interactions for gate opening (Huang et al., 1998; Glaaser and Slesinger, 2017) and are highly expressed in hippocampus (Karschin et al., 1996; Ponce et al., 1996). Previous work in CA1 pyramidal cells demonstrated that $\mathrm{M}_{1} \mathrm{R}$ stimulation reduces GIRK current, presumably via depletion of $\mathrm{PIP}_{2}$ (Sohn et al., 2007), but to our knowledge, such actions on GIRK channels in DG have not been investigated (Lüscher et al., 1997; Lüscher and Slesinger, 2010). Therefore, using receptor-induced, endogenous GIRK current amplitudes as a PIP "biosensor," an increase of $\mathrm{PIP}_{2}$ subsequent to $\mathrm{M}_{1} \mathrm{R}$ stimulation should also increase GIRK currents in DGGCs. We measured GIRK currents elicited by stimulation of $\mathrm{GABA}_{\mathrm{B}}$ receptors (Lüscher et al., 1997) using baclofen (100 $\left.\mu \mathrm{M}\right)$ and GIRK amplitudes compared between control and $10 \mathrm{~min}$ after bath-application of muscarinic agonist to the slice. These experiments were performed in high $\left[\mathrm{K}^{+}\right]_{\mathrm{o}}(20 \mathrm{~mm})$ for GIRK currents to be inward at a holding potential of $-75 \mathrm{mV}$ and of sufficient amplitude to reliably measure (Slesinger et al., 1997). We found that DGGCs from slices perfused with oxo-M (10 $\mu \mathrm{M})$ displayed significantly greater $\mathrm{GABA}_{\mathrm{B}}$-activated GIRK currents (oxo-M + baclofen, $\Delta 110.0 \pm 12.5 \mathrm{pA}$ ) compared with control ACSF condition (baclofen alone, $\Delta 31.0 \pm 6.6 \mathrm{pA}, t_{(10)}=5.59$, $p=0.002, n=6$ cells; Fig. $3 A, B)$. Likewise, specific stimulation of $\mathrm{M}_{1}$ Rs with 77-LH-28-1 enhanced the amplitude of baclofenelicited GIRK currents (77-LH-28-1 + baclofen, $\Delta 123.1 \pm 12.9$ $\mathrm{pA}$; baclofen alone $\left(\Delta 19.3 \pm 2.8 \mathrm{pA}, t_{(4)}=7.86, p=0.01\right)$. Furthermore, incubation of slices with edelfosine ablated the changes to GIRK amplitudes normally stimulated by $\mathrm{M}_{1} \mathrm{Rs}\left(t_{(8)}=0.94\right.$, $p=0.373$; Fig. $3 B$ ). Therefore, $I_{\mathrm{M}}$ and GIRK currents respond in parallel fashion to $G_{q / 11}$-coupled $m A C h R$ stimulation, which is wholly consistent with increase in $\mathrm{PIP}_{2}$ as the underlying modulatory mechanism.

$\mathrm{PIP}_{2}$ is synthesized by sequential phosphorylation of phosphatidylinositol (PI) and PI 4-phosphate (PIP) by PI-4 kinase and phosphatidylinositol-4-phosphate-5 kinase (PIP5K), respectively (Di Paolo et al., 2004; Balla et al., 2008; Volpicelli-Daley et 
A
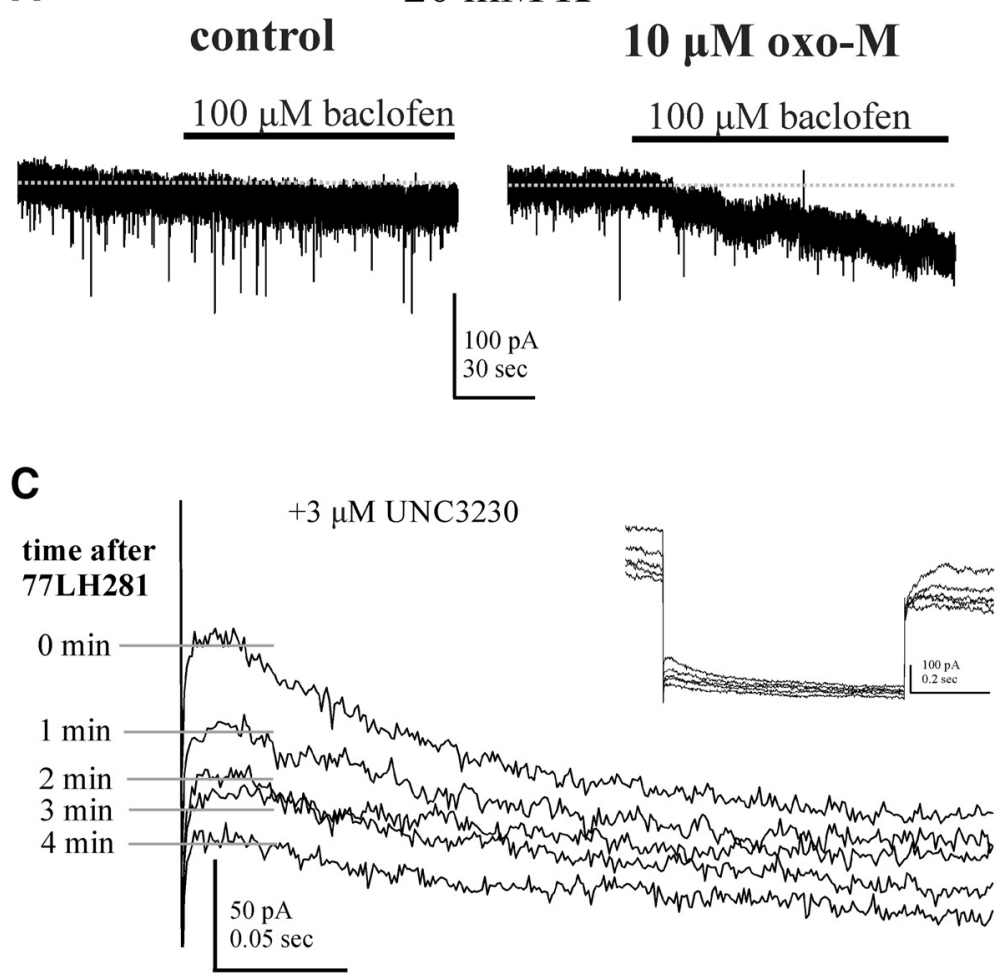

B

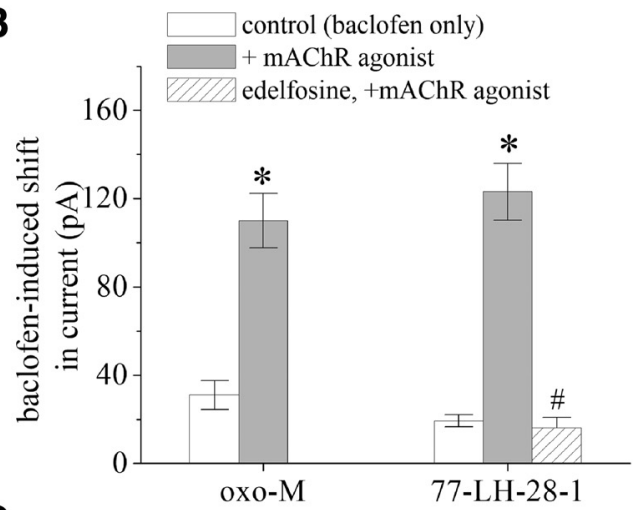

D

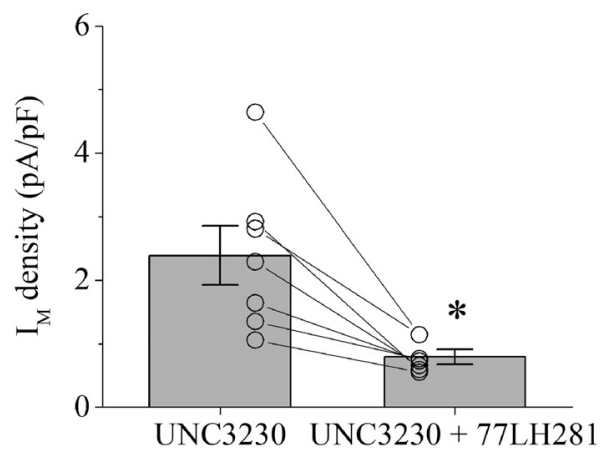

Figure 3. Stimulation of $\mathrm{PIP}_{2}$ synthesis after $\mathrm{mAChR}$ stimulation underlies the enhancement of $I_{M}$ in DGGCs. $A$, Gap-free current recordings before and after stimulation of $G A B A_{B}$ receptors with baclofen $(100 \mu \mathrm{M})$ to evoke inward currents from GIRK channels with $20 \mathrm{~mm}\left[\mathrm{~K}^{+}\right]$in the bath. $B$, Bars summarize the baclofen-evoked in current at the holding potential of $-75 \mathrm{mV}$ before $($ control, white bars) and after bath-application of oxo-M or 77-LH-28-1 (10 $\mu \mathrm{m}$; gray bars) or in the presence of edelfosine (10 $\mu \mathrm{m}$; striped bar). ${ }^{*} p<0.05$ versus control; $\# p<0.05$ versus $+\mathrm{mAChR}$ agonist; $n=5-8$ cells per group. C, Superimposed are deactivating $I_{\mathrm{M}}$ currents from DGGC in the presence of the PIP5K inhibitor UNC3230 (3 $\left.\mu \mathrm{M}\right)$ over a range of $0-4$ min after bath-application of 77-LH-28-1 (3 $\mu \mathrm{M})$. D, Bars summarize the XE-991-sensitive M-current density in the presence of UNC3230 before and after bath-application of 77-LH-28-1. ${ }^{*} p<0.05 ; n=7$ cells.

al., 2010). Furthermore, tonic PIP $_{2}$ abundance is maintained by the homeostatic activity of lipid kinases and phosphatases, reflecting basal turnover (Falkenburger et al., 2010). We assayed the effect of $\mathrm{M}_{1} \mathrm{R}$ stimulation on $I_{\mathrm{M}}$ in DGGCs using UNC 3230, a small-molecule inhibitor of PI(4)P 5-K1C/PI4 K2C kinases (Wright et al., 2014; Fig. 3C,D). Dialysis of cells with UNC 3230 (3 $\mu \mathrm{M}$, pipette solution) resulted in significantly reduced basal $I_{\mathrm{M}}$ amplitudes $\left(2.39 \pm 0.46 \mathrm{pA} / \mathrm{pF}, n=7\right.$ cells, $t_{(33)}=3.06, p=$ 0.008 ). In addition, stimulation of $\mathrm{M}_{1}$ Rs by 77-LH-28-1 (3 $\left.\mu \mathrm{M}\right)$ now resulted in significant suppression of $I_{\mathrm{M}}$ by $61.8 \pm 5.3 \%$ $\left(0.99 \pm 0.11 \mathrm{pA} / \mathrm{pF}, t_{(12)}=2.96, p=0.012, n=7\right.$ cells $)$. Therefore, upon inhibition of PIP5-K1C/PI-4K2C, $\mathrm{M}_{1} \mathrm{R}$ stimulation suppressed $I_{\mathrm{M}}$ in DGGCs, which our evidence shows to occur by depletion of $\mathrm{PIP}_{2}$, due to the impairment of provoked $\mathrm{PIP}_{2}$ synthesis.

\section{KCNQ2-deficient DGGCs exhibit altered gating properties and hyperexcitability}

Given that most $\mathrm{M}$ channels in the nervous system are heteromers of KCNQ2/3 of varying stoichiometry (Gamper and Shapiro, 2015), we exploited the divergent sensitivity of KCNQ2 and KCNQ3 homomers and KCNQ2/3 heteromers to block by TEA (Shapiro et al., 2000; Hadley et al., 2000) to estimate the contribution of KCNQ2 and/or KCNQ3 to $I_{\mathrm{M}}$ in DGGCs. We found the $\mathrm{IC}_{50}$ for block of $I_{\mathrm{M}}$ by TEA to be $6.5 \pm 0.4 \mathrm{~mm}$ (Fig. $4 A$ ) in control DGGCs. At $30 \mathrm{~mm}$ TEA, there was $84.0 \pm 3.0 \%$ reduction in the fast component of $\mathrm{M}$ current and $100 \mathrm{~mm}$ TEA was sufficient to completely abolish the current with a mean $98.8 \pm 0.7 \%$ reduction (Fig. $4 A$ ). This is consistent with $I_{M}$ in DGGCs being almost wholly due to KCNQ2/3 heteromers. Although KCNQ5containing channels have been described in CA1 (Tzingounis et al., 2010), they display a much lower sensitivity to TEA block than do KCNQ2/3 heteromers (Schroeder et al., 2000) and are therefore not likely to significantly contribute to $I_{\mathrm{M}}$ in DGGCs. Our TEA data are consistent with the previous observation that KCNQ5 expression in the DG is very low (Tzingounis et al., 2010). To further confirm that the current in DGGCs that we ascribe to $I_{M}$ is indeed composed of KCNQ2 and KCNQ3 subunits, we investigated DGGC-selective deletion of KCNQ2 by crossing KCNQ2 ${ }^{\text {flox/flox }}$ mice with Cre-POMC mice (McHugh et al., 2007). Analysis of $\mathrm{KCNQ}^{\text {flox/flox }} / \mathrm{Cre}-\mathrm{POMC}^{+}$mice (KCNQ2-deficient) and their control $\mathrm{KCNQ} 2^{\text {flox/flox}} / \mathrm{Cre}-$ $\mathrm{POMC}^{-}$(non-Cre, KCNQ2-control) littermates revealed Crerecombination to be not $100 \%$ efficient in all animals, resulting in a strong knock-down, but not "knock-out," of KCNQ2 subunits as detected by immunoblot measurement of protein $\left(t_{(8)}=4.31\right.$, $p=0.003$ ) and immunohistochemistry (Fig. $4 B, C$ ). We used the TEA dose-response relation to estimate the degree of KCNQ2 knock-down in these neurons. The sensitivity of $I_{\mathrm{M}}$ to TEA current block was significantly reduced compared with non-Cre control DGGCs (Fig. 4A). In KCNQ2-deficient DGGCs, the best estimate of TEA block was $\mathrm{IC}_{50}$ of $82 \pm 11 \mathrm{~mm}$ TEA, significantly right-shifted in potency compared with KCNQ2-control DGGCs $\left(t_{(13)}=6.39, p<0.0001, n=8\right.$ cells $)$. Using the previously described binomial distribution model for TEA block of KCNQ2- and KCNQ3-containing tetramers (Shapiro et al., 2000), we determined $I_{M}$ in KCNQ2-control mice to be composed of channels within $1 \%$ of a $1: 1$ ratio of KCNQ2 and 
A
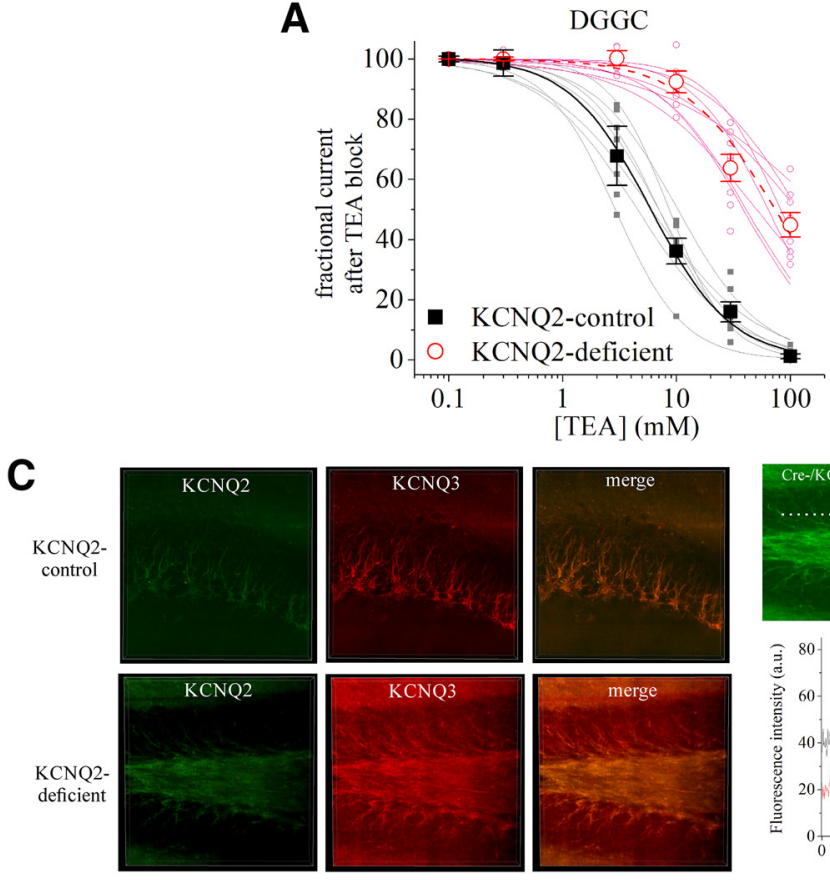

E
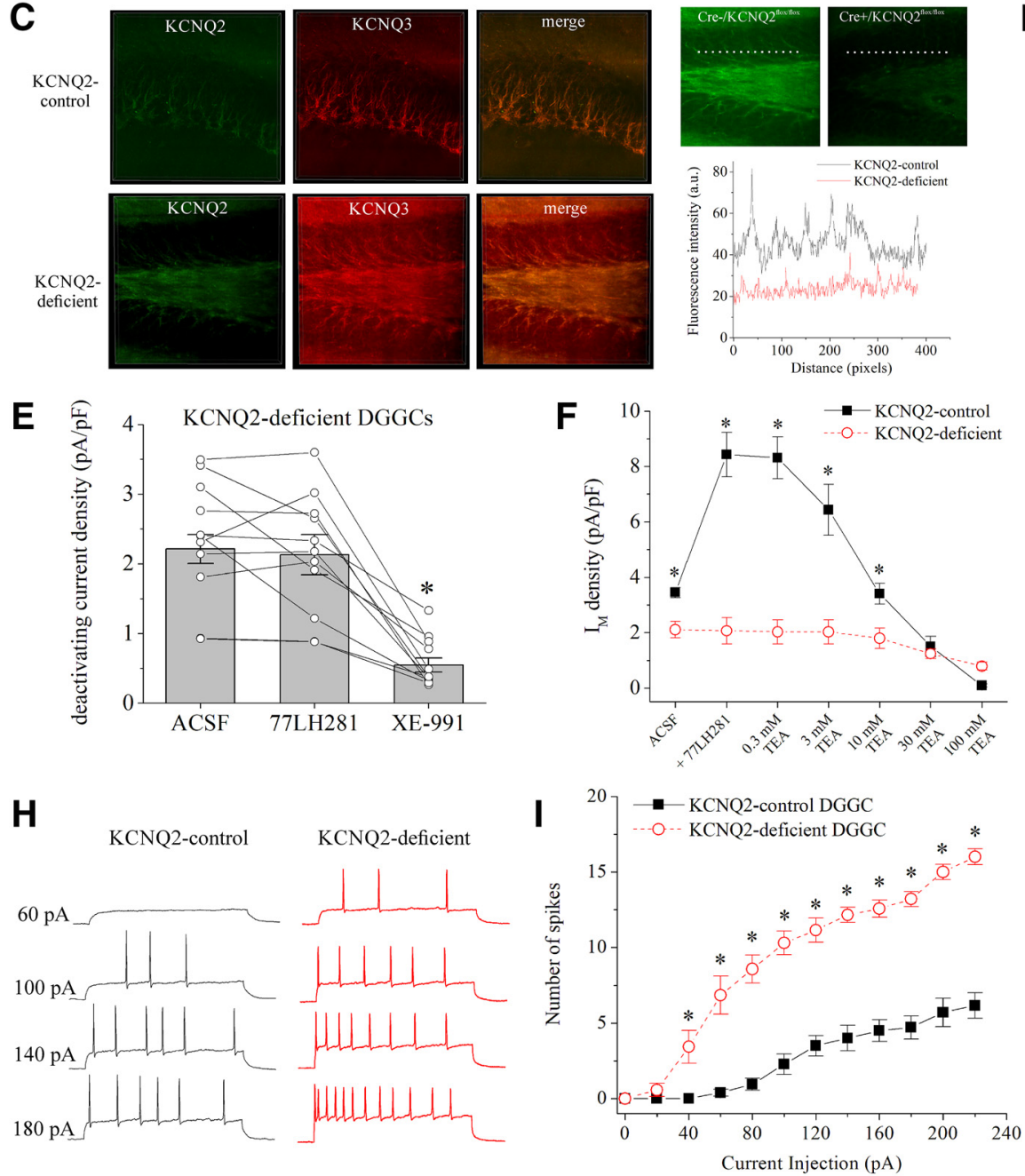

B
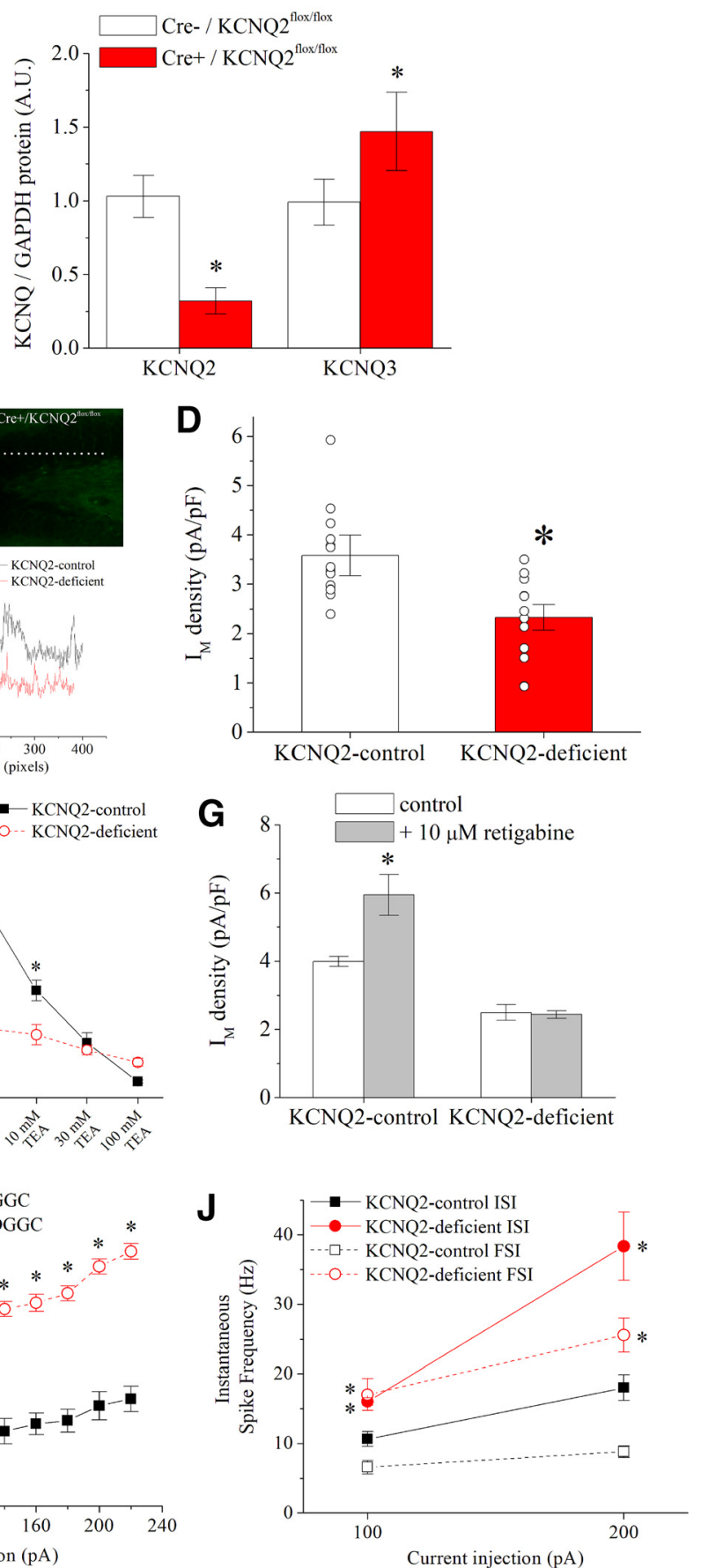

Figure 4. KCNQ2-containing M-channels are required for the $m A C h R$ action on $I M$ and excitability in DGGCs. $A$, TEA sensitivity of deactivating currents from DGGCs of KCNQ-control (squares) or

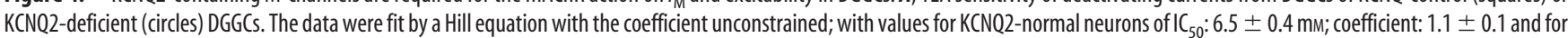
KCNQ2-deficient neurons of $\mathrm{IC}_{50}: 82 \pm 11 \mathrm{~mm}$; coefficient: $1.0 \pm 0.3, n=7-8$ cells per group. $\boldsymbol{B}$, Summarized semiquantified values of DG-localized, KCNQ2 protein immunoblots from Cre-POMC ${ }^{-} /$KCNQ2 $^{\text {flox/flox }}$ (KCNQ2-control) or (re-POMC ${ }^{+} /$KCNQ2 $^{\text {flox/flox }}$ (KCNQ2-deficient) mice normalized to GAPDH ( $n=3$ mice per group). C, Confocal $3 D$ renderings of KCNQ2 immunostaining of fixed DG slices from KCNQ2-control and KCNQ2-deficient mice. Right, Line-scan plots of KCNQ2-labeled fluorescence intensity from either KCNQ2-control (Cre-) or KCNQ2-deficient (Cre +) DG granule layers. $\boldsymbol{D}$, Bars summarize $I_{\mathrm{M}}$ density (pA/pF) in KCNQ2-control and $\mathrm{KCNQ2-deficient} \mathrm{mice.}{ }^{*} p<0.05 ; n=13-15$ cells per group. $\boldsymbol{E}$, Bars summarize the deactivating current density of KCNQ2-deficient DGGCs in control or bath-application of 77-LH-28-1 (3 $\mu \mathrm{M})$ or XE-991 $(20 \mu \mathrm{M}) ; n=11$ cells. ${ }^{*} p<0.05$ versus ACSF condition. $F$, Summarized deactivating current amplitudes of DGGCs from KCNQ2-control (closed squares) and KCNQ2-deficient (open circles) mice in control, in the presence of 77-LH-28-1 (3 $\mu \mathrm{M})$, or TEA over the range from $0.3-10 \mathrm{~mm}$. ${ }^{*} p<0.05$ versus KCNQ2-deficient. G, Bars summarize the potentiation of $I_{M}$ by the M-channel opener retigabine $(10 \mu \mathrm{M})$ in DGGCs from KCNQ2-control or KCNQ2-deficient mice. ${ }^{*} p<0.05$ versus KCNQ2-control. $\boldsymbol{H}$, Representative current-clamp recordings of evoked action potentials in DGGCs from KCNQ2-control and KCNQ2-deficient mice. I, Summarized action-potential spike frequencies as a function of injected current. ${ }^{*} p<0.05 ; n=8-14$ cells per group. $J$, Values of summarized initial spike intervals (ISIs) and final spike intervals (FSIs) during evoked action potentials by current injection of 100 or $200 \mathrm{pA}$ from KCNQ2-control and KCNQ2-deficient DGGCS. ${ }^{*} p<0.05$ versus KCNQ2-control. 
KCNQ3 subunits, whereas $I_{\mathrm{M}}$ from KCNQ2-deficient DGGCs was estimated to be due to channels containing a 0.15:0.85 ratio of KCNQ2 to KCNQ3 subunits, which means that there will be many KCNQ3 homomers, and many heteromers containing only one KCNQ2 subunit, but few others compositions. In DGGCs from KCNQ2-deficient mice, $I_{\mathrm{M}}$ current density at $-55 \mathrm{mV}$ was significantly reduced, to $2.2 \pm 0.2 \mathrm{pA} / \mathrm{pF}(n=13)$, compared with $3.6 \pm 0.3 \mathrm{pA} / \mathrm{pF}$ DGGCs from non-Cre littermates $\left(t_{(28)}=\right.$ $3.88, p=0.0006, n=15$ cells; Fig. $4 D)$. We were unable to detect any significant differences in the rate constants of the current relaxations between KCNQ2-normal and KCNQ2-deficient neurons, consistent with KCNQ2 and KCNQ3 displaying similar deactivation current kinetics (Gamper et al., 2003). Given that macroscopic currents from recombinant KCNQ3 homomers is $\sim 6$-fold less than that of KCNQ2/3 heteromers (Li et al., 2005; Zaika et al., 2008), we were surprised by the modest nature of the reduction in $I_{\mathrm{M}}$ current density in KCNQ2-deficient DGGCs. Nonetheless, the data presented below are wholly consistent with the degree of knock-down suggested by the TEA dose-response, immunostaining, and immunoblot results. We suspect that the KCNQ3-containing channels produce much larger currents when endogenously expressed in brain than when heterologously expressed; however, there is little evidence that KCNQ3 channels traffic as homomers in neurons (Chung et al., 2006a,b). Previous work in cultured superior cervical ganglion neurons found that removal of KCNQ2 leads to increase in KCNQ3 mRNA (Robbins et al., 2013). The mechanisms of compensatory expression upon KCNQ2 deletion may be distinct between peripheral ganglia and brain and even further down to cell-type differences in transcriptional regulation within a given brain region. We observed a modest increase in the protein levels of KCNQ3 subunits in KCNQ2-deficient mice, relative to KCNQ2-normal DGGCs $\left(t_{(8)}=2.32, p=0.048\right.$; Fig. $\left.4 B\right)$ and axonal KCNQ3 expression remained robust in KCNQ2-deficient mice (Fig. 4C).

\section{Muscarinic enhancement of $I_{M}$ is ablated in KCNQ2-deficient DGGCs}

If stimulation of $\mathrm{M}_{1}$ Rs in DGGCs enhances $I_{\mathrm{M}}$ due to increased $\mathrm{PIP}_{2}$ abundance, then another diagnostic test of this hypothesis would be to determine whether KCNQ2 deficiency limits the $\mathrm{M}_{1} \mathrm{R}$-induced enhancement of $I_{\mathrm{M}}$. The apparent affinity of PIP for KCNQ2 homomers is nearly 80-fold lower than for KCNQ3 homomers, with KCNQ2/3 heteromers intermediate, and the open probabilities at saturating voltages are 0.14 for KCNQ2 homomers, $\sim 0.3$ for KCNQ2/3 heteromers and $>0.9$ for KCNQ3 homomers at normal basal $\mathrm{PIP}_{2}$ intracellular concentrations $(\mathrm{Li}$ et al., 2004, 2005; Telezhkin et al., 2012). Therefore, an increase in tonic $\mathrm{PIP}_{2}$ abundance can significantly increase macroscopic KCNQ2 currents and could increase KCNQ2/3 currents, but has little effect on currents from KCNQ3 channels, the latter being already fully saturated with $\mathrm{PIP}_{2}$ (Li et al., 2004). Therefore, we compared $I_{\mathrm{M}}$ of DGGCs from KCNQ2-deficient mice with KCNQ2-normal littermate controls. Whereas stimulation of $\mathrm{M}_{1}$ Rs in non-Cre controls with 77-LH-28-1 (3 $\left.\mu \mathrm{M}\right)$ resulted in a $1.9 \pm 0.1$-fold increase in $I_{\mathrm{M}}$ density $(3.27 \pm 0.28 \mathrm{pA} / \mathrm{pF}, n=12)$, stimulation of $\mathrm{M}_{1}$ Rs in DGGCs from KCNQ2-deficient mice did not significantly affect $I_{\mathrm{M}}$ density (before stimulation: $2.21 \pm 0.21$ $\mathrm{pA} / \mathrm{pF}$ vs after stimulation: $2.13 \pm 0.29 \mathrm{pA} / \mathrm{pF} ; t_{(22)}=0.22, p=$ 0.82; Fig. $4 E$ ). However, $I_{\mathrm{M}}$ from KCNQ2-deficient DGGCs was strongly blocked by XE-991 (20 $\mu$; Fig. $4 E)$. To confirm the strong knock-down of KCNQ2 in these experiments and to determine whether the $\mathrm{mAChR}$-mediated enhanced $I_{\mathrm{M}}$ in control neurons is from KCNQ2/3 heteromers, we examined block by
TEA for both groups of neurons in the presence of 77-LH-28-1 (Fig. $4 F$ ). For the neurons with unaltered expression of KCNQ2 subunits, the TEA $\mathrm{IC}_{50}$ blockade of the enhanced current occurred at $3 \mathrm{~mm}$ and above, indicating that the bulk of current was from KCNQ2/3 heteromers. However, for the KCNQ2-deficient DGGCs, in which $I_{M}$ was not affected by mAChR stimulation, the current was highly insensitive to TEA, as expected and representative of KCNQ3 homomers.

Retigabine (RTG) is the prototypic anticonvulsant compound that targets M-channels (Rundfeldt and Netzer, 2000). Based on the above findings based on increases in tonic $\mathrm{PIP}_{2}$, we wished to compare the action of RTG on $I_{M}$ between DGGCs of KCNQ2control mice with those from KCNQ2-deficient mice. RTG is known to enhance M-channel opening in a bimodal fashion: by shifting the voltage dependence of activation to more negative potentials and by increasing channel open probability at all voltages (Tatulian et al., 2001; Tatulian and Brown, 2003). Whereas RTG $(10 \mu \mathrm{M})$ enhanced $I_{\mathrm{M}}$ in KCNQ-control DGGCs, it did not significantly alter $I_{\mathrm{M}}$ amplitudes in KCNQ2-deficient neurons (Fig. 4G). These results are consistent with those of Tatulian et al. (2001), who showed that RTG does not increase the fractional voltage dependence of KCNQ3 channels at $-25 \mathrm{mV}$, the voltage tested here, but does shift the voltage dependence of KCNQ2 channels, which is therefore consistent with the different open probabilities of KCNQ2, KCNQ3, and KCNQ2/3 channels (Selyanko et al., 2001; Li et al., 2004).

Only a $25 \%$ reduction in $I_{M}$ in brain is sufficient for the manifestation of epileptic seizures (Schroeder et al., 1998). Therefore, we investigated the effects of KCNQ2 deficiency on DGGC discharge properties. Under whole-cell current-clamp conditions, KCNQ2-deficient granule cells displayed greater excitability properties, including increased action potential frequency, reduced SFA, and increased interspike intervals (Fig. 4H-J). In addition, the rheobase for action potential firing was of significantly smaller amplitude for KCNQ2-deficient DGGCs (KCNQ2normal: $73.5 \pm 3.0 \mathrm{pA}$; KCNQ2-deficient: $33.4 \pm 4.6 \mathrm{pA} ; t_{(20)}=$ $7.62, p<0.0001)$. All of these altered properties are consistent with reduced $I_{\mathrm{M}}$ amplitudes, underscoring the sensitivity of DGGCs to even modest changes in $I_{\mathrm{M}}$. They also predict that M-channel openers such as RTG are likely to be less efficacious in the clinical setting to treat hyperexcitability syndromes resulting in decreased expression of KCNQ2 gene products such as reported in animal pain models (Mucha et al., 2010), but more efficacious for disorders such as idiopathic epilepsy, in which KCNQ2 expression in brain may be selectively upregulated (Zhang and Shapiro, 2012).

\section{Effects of $\mathrm{mAChR}$ stimulation on $I_{\mathrm{M}}$ of DGGCs do not correlate with the alteration in neuronal excitability}

DGGCs exhibit a very low basal firing rate (Jung and McNaughton, 1993). Furthermore, mAChR stimulation increases DGGC firing and mossy fiber neurotransmission to CA3 and CA1 (Vogt and Regehr, 2001). Our data here show an increase in $I_{\mathrm{M}}$ upon $\mathrm{M}_{1} \mathrm{R}$ stimulation, which would ordinarily be expected to decrease excitability, presenting us with an apparent conundrum. To parse this question, we first assayed the changes in active and passive discharge properties of DGGCs in response to $M_{1} R$ stimulation in the slice (Fig. 5). Bath-application of oxo-M (10 $\mu \mathrm{M})$ shifted the action potential threshold of DGGCs from WT mice by $-5.6 \pm 1.0 \mathrm{mV}$ (ACSF: $-46.3 \pm 0.8 \mathrm{mV}$, oxo-M: $-51.3 \pm 1.2$ $\mathrm{mV} ; t_{(16)}=3.47, p=0.004, n=9$ cells), whereas in DGGCs from $\mathrm{M}_{1} \mathrm{R}$ KO mice, the mean shift of $-0.9 \pm 0.5 \mathrm{mV}$ was not significantly different (ACSF: $-47.2 \pm 1.7 \mathrm{mV}$, oxo-M: $-48.1 \pm 1.8$ 
A
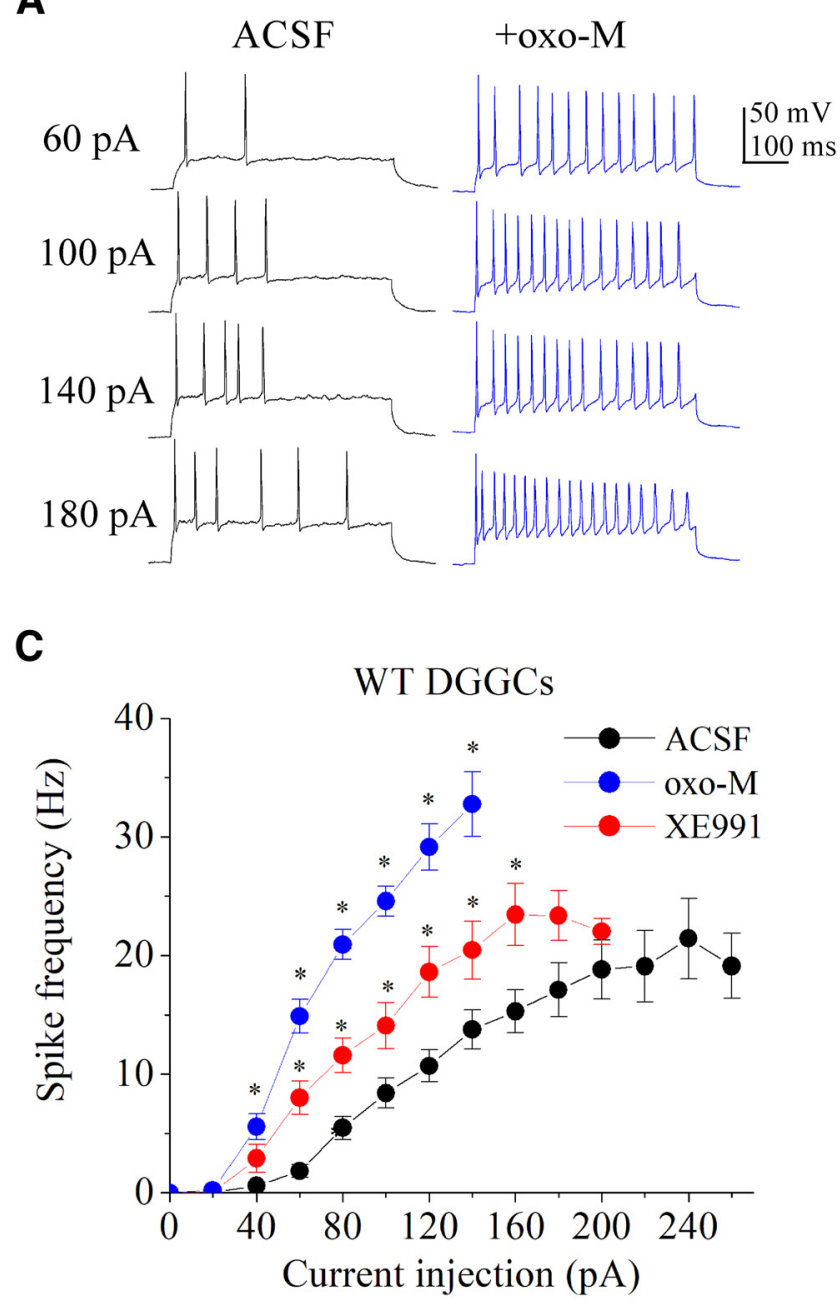

E

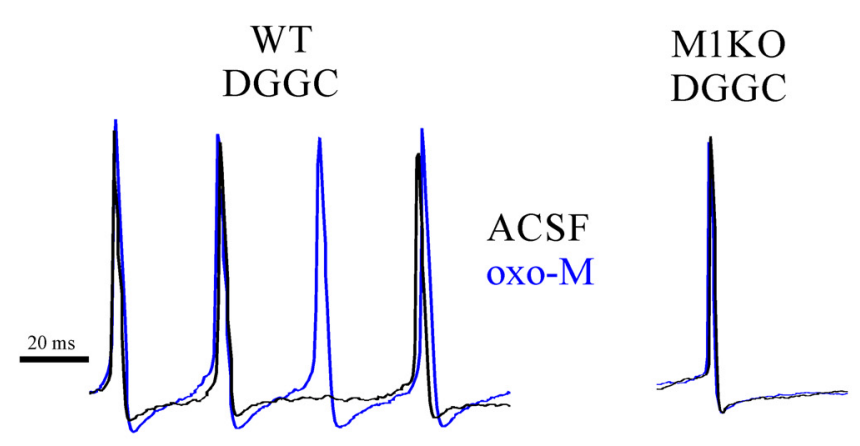

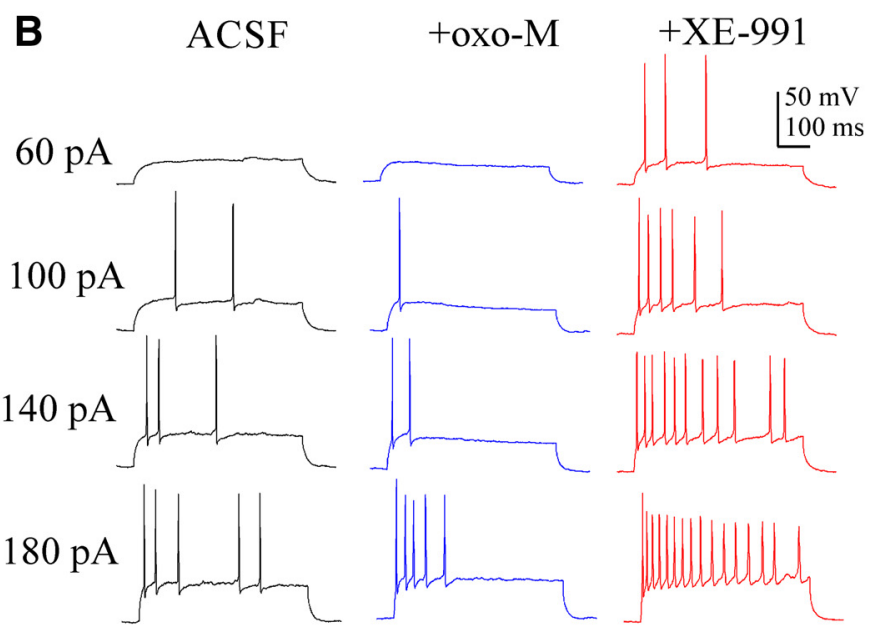
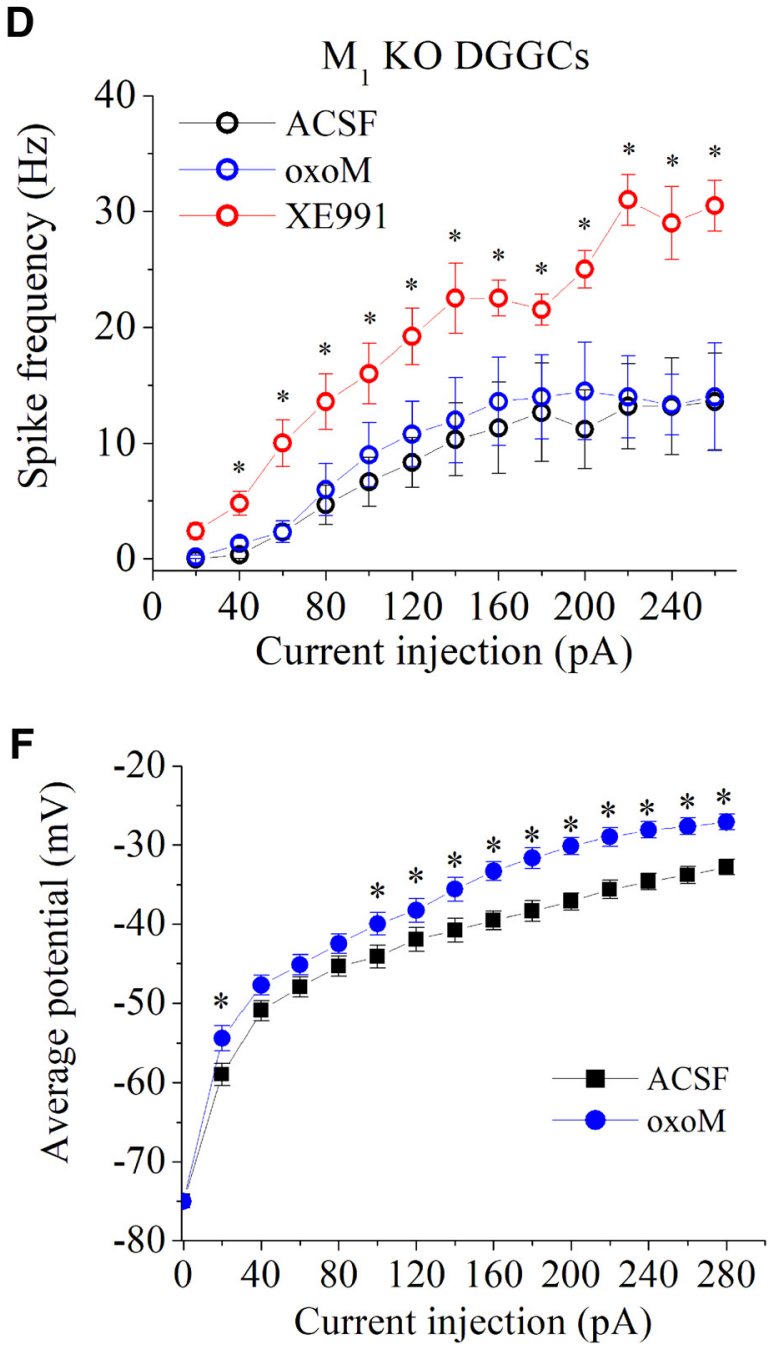

Figure 5. Hyperexcitability of DGGCs induced by stimulation of $M_{1} A C h R s . A, B$, Representative current-clamp recordings of evoked action potentials in DGGCs from WT ( $\boldsymbol{A}$ ) or $\mathrm{M}_{1} \mathrm{R}$ KO$(\boldsymbol{B})$ mice in response to $\mathrm{mAChR}$ stimulation by oxo-M (10 $\mu \mathrm{M})$. C, D, Plots summarize the change in action potential frequency induced by application of oxo-M (10 $\mu \mathrm{m})$ or XE-991 (20 $\mu \mathrm{m})$ in DGGCs from WT (C; $n=10$ cells) or $\mathrm{M}_{1} \mathrm{RKO}$ (D; $n=7$ cells). Scale bars, $100 \mathrm{~ms}, 50 \mathrm{mV}$. Action potential properties derived from current-clamp experiments are listed in Figure 5-1, available at https://doi.org/10.1523/ JNEUROSCI.1781-18.2018.f5-1. E, Representative action potential waveforms before (black) and after mAChR stimulation with oxo-M (blue). $\boldsymbol{F}$, Summarized membrane potential values (voltage floor) over ranges of current injection $(0-280 \mathrm{pA})$ from neurons before (ACSF) or after stimulation of mAChRs with $0 \times 0-\mathrm{M}(10 \mu \mathrm{M}) . n=7$ cells. ${ }^{*} p<0.05$ versus ACSF.

$\mathrm{mV} ; t_{(12)}=0.36, p=0.72, n=7$ cells). During whole-cell current-clamp recordings with zero injected current (i.e., at resting membrane potential, $\left.V_{\mathrm{m}}\right)$, DGGCs did not spontaneously fire. However, bath-application of oxo-M $(10 \mu \mathrm{M})$ depolarized
$V_{\mathrm{m}}$ significantly and increased spontaneous action potential firing. Input/output relationships of DGGCs were compared between control conditions, during $\mathrm{M}_{1}$ R stimulation, or when $I_{\mathrm{M}}$ was blocked. Action potential firing rate was quantified as a func- 
tion of injected current over a range from 0 to $250 \mathrm{pA}$. During control conditions, neurons exhibited pronounced SFA, thought to be heavily dependent on $I_{\mathrm{M}}$. Stimulation of $\mathrm{M}_{1}$ Rs with oxo-M $(10 \mu \mathrm{M})$ strongly increased the action potential frequency at all values of injected current and abolished SFA to the point at which by $140 \mathrm{pA}$, the firing rate could not increase further due to "depolarization block" (accumulated inactivation of $\mathrm{Na}^{+}$channels; Fig. $5 A, C)$. Interestingly, under block of $I_{\mathrm{M}}$ with XE-991 $(20 \mu \mathrm{M})$, the rate of firing significantly increased and SFA was reduced, but both effects were less compared with muscarinic agonist, suggesting that the latter involves other factors in addition to control of $I_{\mathrm{M}}$.

Parallel experiments were performed on slices from $\mathrm{M}_{1} \mathrm{KO}$ mice. Compared with WT, basal excitability of neurons was reduced, and SFA was more pronounced, possibly incident of a low level of tonic activity of $\mathrm{M}_{1}$ Rs in slices from WT mice or to greater expression of $\mathrm{M}$ channels in $\mathrm{M}_{1} \mathrm{KO}$ mice. As expected, DGGCs from $\mathrm{M}_{1} \mathrm{KO}$ mice did not display changes to neuronal firing as a result of bath-application of oxo-M (Fig. $5 B, D$ ). However, block of $I_{\mathrm{M}}$ with XE-991 $(20 \mu \mathrm{M})$ strongly increased action potential frequency and significantly decreased SFA (Fig. 5C). In slices from WT mice, action potential width was significantly increased upon stimulation of neurons by oxo-M (ACSF: $4.01 \pm 0.17 \mathrm{~ms}$; oxo-M: $\left.4.67 \pm 0.27 \mathrm{~ms}, t_{(12)}=2.07, p=0.03\right)$. The AHP displayed a significantly slower rate of decay $(12.9 \pm 1.4$ vs $18.8 \pm$ $0.4 \mathrm{~ms}, t_{(12)}=4.05, p=0.001, n=7$ cells), resulting in a significantly larger area of the AHP (defined as $\mathrm{mV}^{\star} \mathrm{ms} ; 173 \pm 23$ vs $270 \pm 12$; fold change: $1.79 \pm 0.23, n=7$ cells, $t_{(12)}=3.74, p=$ 0.002; Fig. $5 E$ and Fig. 5-1, available at https://doi.org/10.1523/ JNEUROSCI.1781-18.2018.f5-1). A complementary parameter is the mean potential of the cell during the time of current injection, called the "voltage floor." In these experiments, a tonic level of current was first injected to maintain the cell at $-75 \mathrm{mV}$ to isolate voltage changes due to action potential firing. Because the voltages involved are in the pivotal range for action potential initiation, these magnitudes in $\Delta \mathrm{V}$ are highly significant for affecting excitability. At nearly all values of injected current, stimulation of $\mathrm{M}_{1}$ Rs caused a significant depolarization of the mean potential, ranging from 4 to $10 \mathrm{mV}$ (Fig. $5 F$ ). As a measure of the instantaneous SFA, the initial interspike interval was significantly increased after bath-application of oxo-M at the lowest current that elicited two action potentials (Fig. 5-1, available at https:// doi.org/10.1523/JNEUROSCI.1781-18.2018.f5-1), meaning that muscarinic stimulation induced hyperexcitability of DGGCs.

Selective stimulation of $\mathrm{M}_{1}$ Rs with 77-LH-28-1 (0.3 or $3 \mu \mathrm{M}$ ) resulted in similar increase to the excitability of DGGCs in slices from WT mice (Fig. 6A). Action-potential threshold was significantly reduced at $3 \mu \mathrm{M}$ 77-LH-28-1 $(-44.7 \pm 0.9 \mathrm{mV}$ vs $-51.9 \pm$ $1.7 \mathrm{mV} ; t_{(10)}=3.74, p=0.0038, n=6$ cells). As a complementary experiment to those above in voltage clamp that suggested $M_{1} R$ induced stimulation of $\mathrm{PIP}_{2}$ synthesis, we performed currentclamp recordings in the presence of UNC $3230(3 \mu \mathrm{M})$ to determine whether block of $\mathrm{PIP}_{2}$ synthesis would affect the intrinsic firing properties of DGGCs accordingly. In the presence of the PI(4)P-5K inhibitor, DGGCs demonstrated greater action potential frequency (Fig. $6 \mathrm{~B}$ ) and the AHP amplitude was significantly reduced after $\mathrm{M}_{1} \mathrm{R}$ stimulation compared with action potentials in control conditions $\left(t_{(24)}=9.57, p<0.0001\right.$; Fig. $\left.6 C\right)$. Therefore, the current-clamp and voltage-clamp recordings under block of PI(4)P-5 kinases are consistent with a reduction of $I_{\mathrm{M}}$. Blockade of nicotinic acetylcholine receptors with the antagonist hexamethonium (50 $\mu$ m; Papke et al., 2010) did not significantly affect DGGC excitability (Fig. 6D).

\section{Exogenous $\mathrm{G}_{\mathrm{q}}$-coupled muscarinic DREADD receptors enhance $I_{M}$ in DGGCs}

As another way to isolate the $\mathrm{G}_{\mathrm{q}}$-coupled muscarinic receptor signaling input onto DGGCs, we used DREADDs, which allow tissue- and cell-specific interrogation of signal transduction when driven behind the appropriate promoter for expression of Cre-recombinase (Roth, 2016). We inserted exogenous $\mathrm{G}_{\mathrm{q}}$ coupled muscarinic hM3Dq receptors (Alexander et al., 2009) in the brains of mice to determine whether selective stimulation with its cognate synthetic agonist, clozapine- $\mathrm{N}$-oxide $(\mathrm{CNO})$, would affect $I_{\mathrm{M}}$ similarly to stimulation of endogenous $\mathrm{M}_{1}$ Rs in DGGCs. To produce germline mice expressing hM3Dq receptors exclusive to DGGCs, we crossed floxed hM3Dq-HA mice with mice expressing Cre driven by the POMC promoter (Alexander et al., 2009; Zhu et al., 2016; Fig. 7A). Specific expression was confirmed via visualization of the mCitrine fluorescent tag of the DREADDs in brain slices during electrophysiology recordings (Fig. 7B). Upon bath-application of CNO to DREADDexpressing DGGCs $\left(\mathrm{Cre}^{+} / \mathrm{DREADD}^{+/-}\right), I_{\mathrm{M}}$ amplitude was maximally increased $2.51 \pm 0.26$-fold by $1 \mu \mathrm{M}$ CNO, similar to the effect observed upon stimulation of endogenous $\mathrm{M}_{1}$ Rs (Fig. $7 D$ ). As a negative control, we recorded from DGGCs of DREADD transgenic mice without Cre-recombinase $\left(\mathrm{Cre}^{-} / \mathrm{DREADD}^{+/-}\right)$ that did not express hM3Dq receptors. CNO had no significant effect on $I_{\mathrm{M}}$ in DGGCs from $\mathrm{Cre}^{-} / \mathrm{DREADD}^{+/-}$mice; however, oxo-M application still significantly enhanced $I_{\mathrm{M}}$ amplitude $\left(t_{(12)}=2.50, p=0.028, n=7\right.$ cells; Fig. $\left.7 D\right)$. Therefore, stimulation of exogenous $\mathrm{G}_{\mathrm{q}}$-coupled mAChRs in DGGCs enhances $I_{\mathrm{M}}$ similarly to native $\mathrm{M}_{1}$ Rs. Furthermore, in DGGCs from $\mathrm{Cre}^{+}$/ DREADD $^{+/-}$mice, bath-application of CNO $(0.1$ or $0.3 \mu \mathrm{M})$ hyperpolarized the action potential threshold (Fig. 7C) and significantly increased the action potential frequency (Fig. 7E). Together, these data indicate that stimulation of $\mathrm{G}_{\mathrm{q}}$-coupled mAChRs robustly increases DGGC excitability and that there must be other downstream effectors of PLC activation that contribute to this effect, in seeming counteraction to the potentiation of $I_{\mathrm{M}}$.

\section{M-channel openers enable $I_{M}$ to counteract the $M_{1} R$-induced hyperexcitability of DGGCs}

Stimulation of mAChRs in GABAergic neurons in the stratum oriens of CA1, which spontaneously fire rapid action potentials, are quickly silenced via drug-induced augmentation of $I_{\mathrm{M}}$ (Lawrence et al., 2006a,b,c). We investigated whether first enhancing $I_{\mathrm{M}}$ activity with M-channel openers before muscarinic stimulation would counteract the excitability while still enabling greater $I_{\mathrm{M}}$ augmentation in DGGCs (Fig. 8). To accomplish this, we acquired current-clamp recordings of evoked action potentials in the presence of RTG $(10 \mu \mathrm{M})$ or the KCNQ2/3-selective compound, ICA-069673 $(10 \mu \mathrm{M})$. Following this, we bath-applied 77-LH-28-1 ( $3 \mu \mathrm{M})$ for $10 \mathrm{~min}$ and then again recorded evoked action potentials. The presence of RTG or ICA-069673 maintained low spiking frequency of DGGCs after mAChR stimulation compared with the robust hyperexcitability observed during 77-LH-28-1 without preapplication of M-channel openers (Fig. $8 A$ ). Whereas control stimulation of $\mathrm{M}_{1}$ Rs with 77-LH-28-1 significantly reduced the rheobase of current required for evoking action potential firing $\left(t_{(8)}=5.71, p=0.0005\right)$, in the presence of either RTG or ICA-069673, the rheobase did not significantly change after application of 77-LH-28-1 (RTG: $t_{(10)}=2.11, p=$ 0.06; ICA-069673: $t_{(10)}=0.69, p=0.50$; Fig. $8 B$ ). Therefore, preapplication of $\mathrm{M}$-channel openers before $\mathrm{mAChR}$ stimulation 

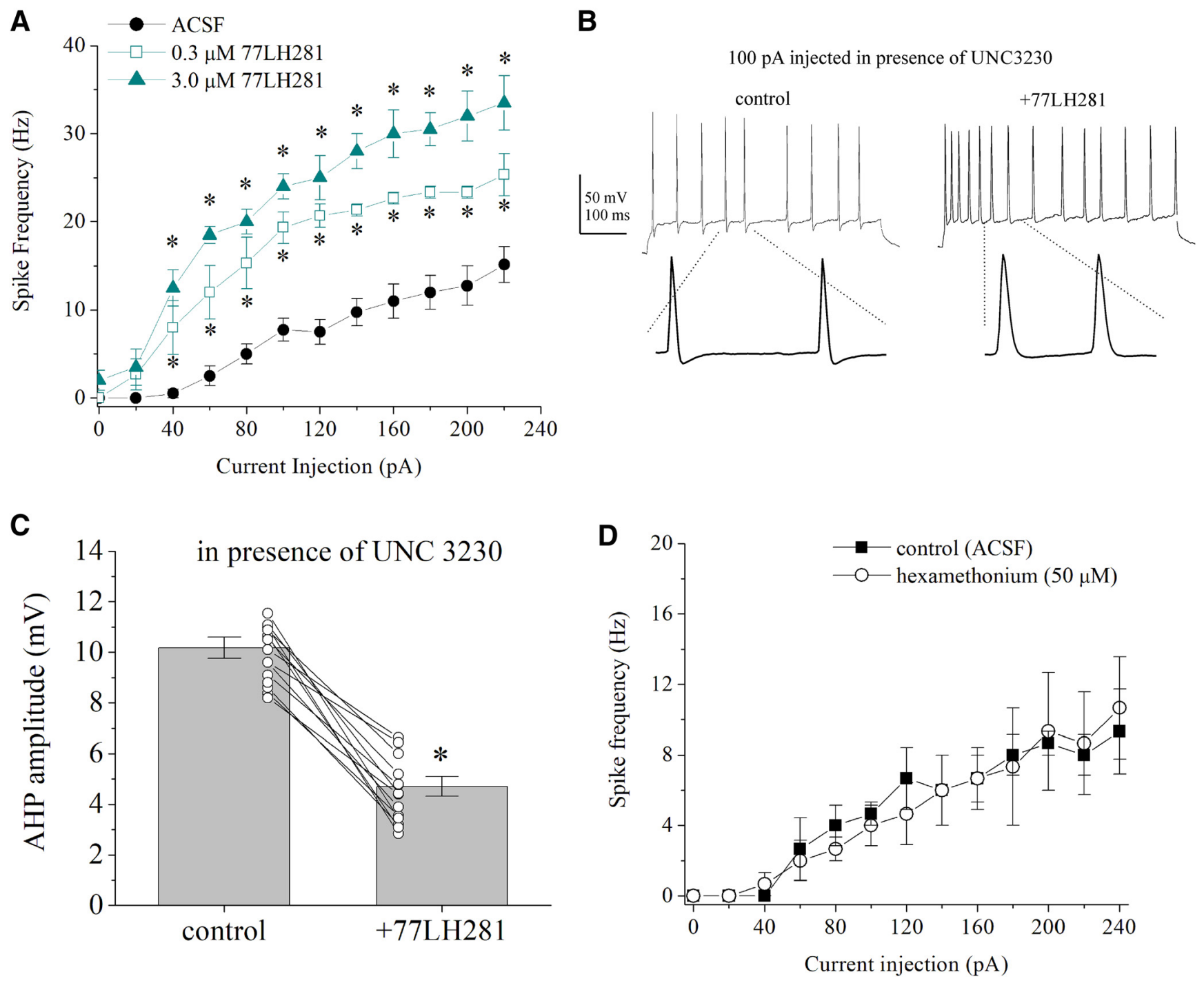

Figure 6. Selective stimulation of endogenous $\mathrm{M}_{1}$ muscarinic receptors induces $\mathrm{DGGC}$ hyperexcitability, mediated by stimulation of PIP ${ }_{2}$ synthesis. $A$, Summarized action potential frequencies before (ACSF, filled circles) and after bath-application of 77-LH-28-1 at $0.3 \mu \mathrm{m}$ (open squares) or $3.0 \mu \mathrm{m}$ (filled triangles; $n=6-8$ cells per group, ${ }^{*} p<0.05$ versus ACSF. $\boldsymbol{B}$, Representative current-clamp recordings of action potentials in the presence of UNC3230 ( $3 \mu \mathrm{m})$ before (control) and after bath-application of 77-LH-28-1 ( $3 \mu \mathrm{M})$. C, Bars summarize the AHP amplitudes before and after 77-LH-28-1 application in the presence of UNC3230. Blockade of PIP ${ }_{2}$ synthesis during mAChR stimulation resulted in hyperexcitability of DGGCs, consistent with M-current suppression. ${ }^{*} p<$ 0.05. D, Summarized action potential frequencies plots before (ACSF, filled squares) and after bath-application of hexamethonium chloride (50 $\mu \mathrm{m}$, open circles); $n=4$ cells.

enables $I_{\mathrm{M}}$ to inhibit and fully oppose the hyperexcitability produced by mAChRs.

Stimulation of $\mathrm{G}_{\mathrm{q} / 11}$-coupled $\mathrm{M}_{1}$ Rs of DGGCs induces increases in $\left[\mathrm{Ca}^{2+}\right]_{\mathrm{i}}$ mostly via TRPC channels, the activity of which mediates increased excitability

Our data in DGGCs thus far indicate that $M_{1} R$ stimulation enhances $I_{M}$ amplitude, yet robustly increases active and passive excitability, conferring higher rates of action potential firing. We hypothesized the involvement of another excitatory ion channel that would be activated downstream of $\mathrm{G}_{\mathrm{q} / 11}$ activation and PLC. We investigated whether stimulation of $M_{1}$ Rs could provoke rises in $\left[\mathrm{Ca}^{2+}\right]_{\mathrm{i}}$ because such rises have been shown to be the determining factor in whether $\mathrm{G}_{\mathrm{q} / 11}$-coupled receptor stimulation depletes PIP $_{2}$ in sympathetic neurons (Hernandez et al., 2008a,b). Indeed, cholinergic stimulation has been shown to increase $\left[\mathrm{Ca}^{2+}\right]_{\mathrm{i}}$ in the soma and mossy fiber axons of DGGCs (Itou et al., 2011). To investigate $\left[\mathrm{Ca}^{2+}\right]_{\mathrm{i}}$ dynamics of DGGCs in slices, we performed $\mathrm{Ca}^{2+}$ imaging in whole-cell mode with the cell- impermeant fluorescent reporter calcium-green 1 in the internal pipette solution (Fig. 9A). In response to $\mathrm{M}_{1} \mathrm{R}$ stimulation by 77-LH-28-1 (3 or $10 \mu \mathrm{M}$ ), peak fluorescence increased $2.91 \pm$ 0.41 -fold or $4.27 \pm 0.95$-fold, respectively (Fig. 9B). The $\mathrm{Ca}^{2+}$ signal began to increase within $1 \mathrm{~min}$ after muscarinic agonist application to the slice, concurrent with the time at which granule cell action potential firing frequency increased, as well as enhancement of $I_{\mathrm{M}}$ amplitude. $\left[\mathrm{Ca}^{2+}\right]_{\mathrm{i}}$ reached a maximum, as detected by dye fluorescent emission, 10 min after application of muscarinic agonist. Whereas calibration of the intensity dye is not feasible (Zhou and Neher, 1993), we estimate, based on our previous work, that the maximum $\left[\mathrm{Ca}^{2+}\right]_{\mathrm{i}}$ rise to be well above 1 $\mu \mathrm{M}$. When slices were preincubated with edelfosine $(10 \mu \mathrm{M}), 77-$ LH-28-1 had no significant effect on $\left[\mathrm{Ca}^{2+}\right]_{\mathrm{i}}$ (maximum dye emission $=1.15 \pm 0.08$-fold over that before agonist; Fig. $9 A, B$ ). An important question is whether these $\left[\mathrm{Ca}^{2+}\right]_{\mathrm{i}}$ rises evoked by muscarinic stimulation require the release of $\mathrm{Ca}^{2+}$ from intracellular ER stores. To address this, we repeated $\mathrm{Ca}^{2+}$ imaging experiments using the $\mathrm{IP}_{3}$ receptor inhibitor xestospongin $\mathrm{C}(10 \mu \mathrm{M})$ 
A

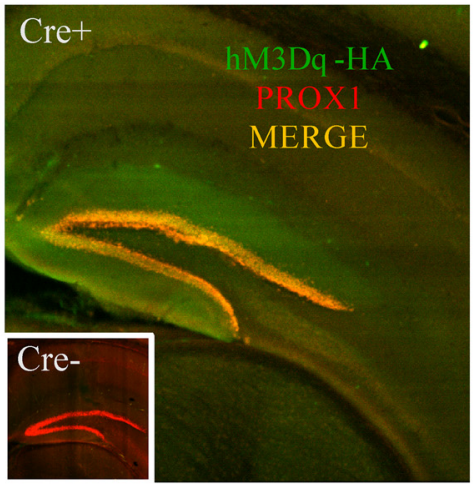

B
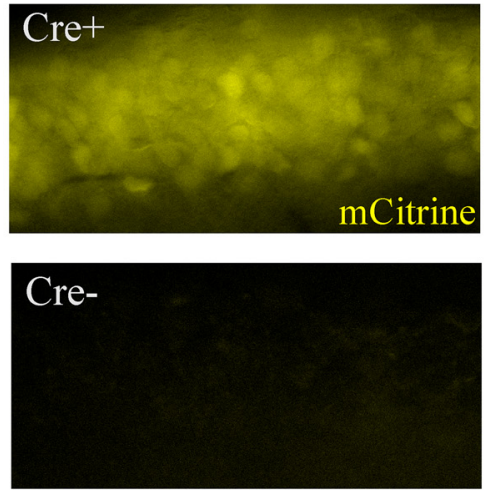

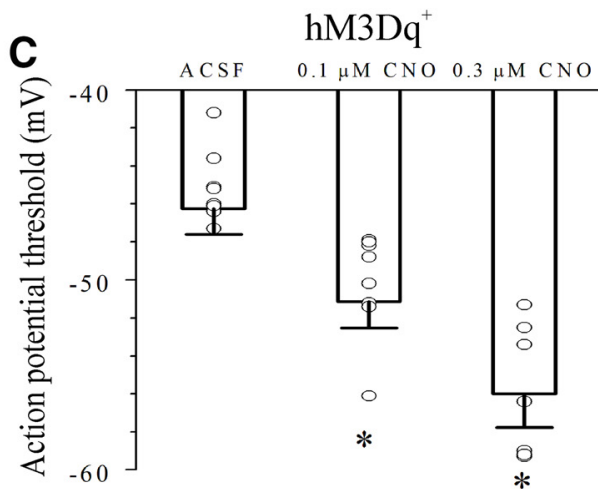

D

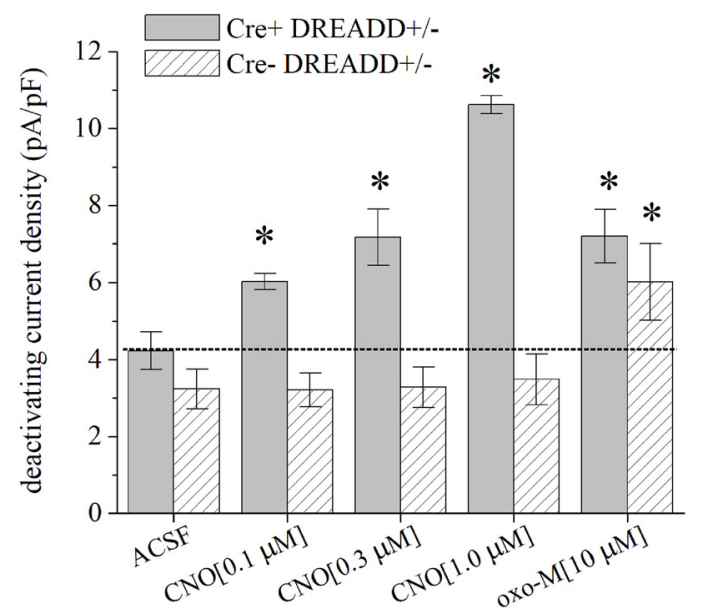

E

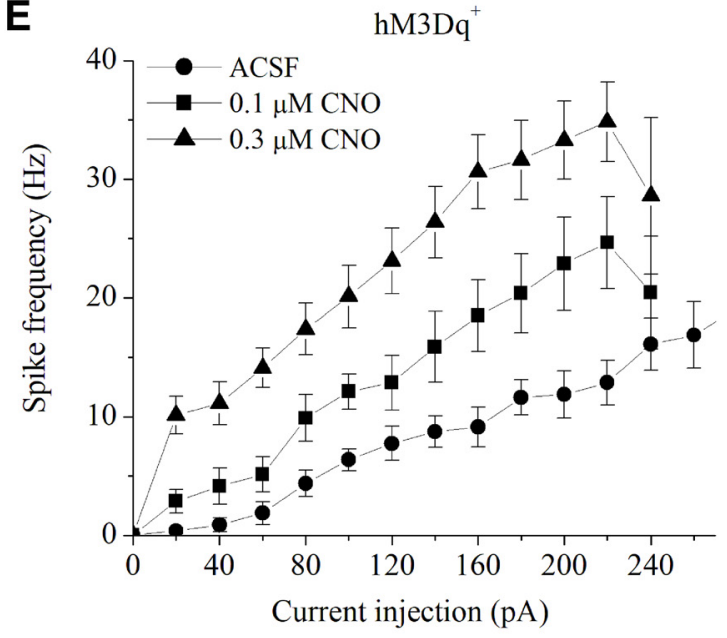

Figure 7. Stimulation of exogenous $G_{q}$-coupled muscarinic DREADD receptors enhances $I_{M}$ in DGGCs. $A$, Confocal images of hippocampal slices immunostained for $H A$-tagged $h M 3 D q$ receptors (green) and counterstained with PROX1 (red), a cellular marker of DGGCs, from a Cre POMC ${ }^{+}$mouse. The hM3Dq-HA tagged fluorescence was present in the molecular (dendrites) and granule (soma) layers of the DG, but not the hilus (mossy fiber axons). CrePOMC ${ }^{+} \mathrm{hM} 3 \mathrm{Dq}$ mice displayed exclusive expression of DREADD receptors to the somatodendritic compartment of DGGCs. The CA1 and CA3 regions did not demonstrate hM3Dq expression. Inset, Confocal micrograph from a $\mathrm{CrePOMC}^{-}$hippocampus negative control demonstrating no hM3Dq receptor expression. $\boldsymbol{B}$, Fluorescent images show either CrePOMC ${ }^{+}$hM3Dq-mCitrine fluorescence (top) or CrePOMC ${ }^{-}$(bottom) granule layer live slices used for electrophysiology recordings obtained using a $488 \mathrm{~nm}$ emission filter. C, Summarized current-clamp action potential thresholds of hM3Dq-expressing DGGCs before (ACSF) and after bath-application of CNO (0.1 or $0.3 \mu \mathrm{m} ; n=7$ cells, $\left.{ }^{*} p<0.05\right)$. D, Bars summarize the enhancement of $I_{M}$ by bath-application of $C N 0$ to DGGCs with transgenic insertion of hM3Dq DREADDs (Cre ${ }^{+}$DREADD ${ }^{+/-}$, gray solid bars) specific to DG or in control littermate DGGCs not expressing hM3Dq-DREADDs from mice that lack the Cre gene (Cre ${ }^{-}$DREADD $^{+/-}$, striped bars). The dashed line represents mean $I_{M}$ amplitude for ACSF (control) in Cre + DREADD ${ }^{+/-}$mice. $\boldsymbol{E}$, Summarized current-clamp action potential spike frequencies from hM3Dq-expressing DGGCs ( $n=7$ cells).

to block $\mathrm{IP}_{3}$ receptor-mediated release of $\mathrm{Ca}^{2+}$ (Gafni et al., 1997). We found that despite blockade of $\mathrm{IP}_{3}$ receptors, $\mathrm{mAChR}$ stimulation still provoked substantial rises in $\left[\mathrm{Ca}^{2+}\right]_{\mathrm{i}}$ (Fig. 9A,B) and increase to DGGC hyperexcitability was still observed upon $\mathrm{mAChR}$ stimulation, as indicated by increased action potential firing frequency (Fig. 9C).

What excitatory ion channel could be activated downstream of mAChR-induced PLC activity, act as a source of sustained rise in $\left[\mathrm{Ca}^{2+}\right]_{\mathrm{i}}$, and induce marked increases in excitability of DGGCs? TRPC cation channels are activated by PLC-mediated signals (Strübing et al., 2001), permeant to $\mathrm{Ca}^{2+}$ influx, and are known to be highly expressed in DG and hippocampus, consisting of TRPC1/4/5 heteromers (Chung et al., 2006a,b; Ramsey et al., 2006; Fowler et al., 2007; Wu et al., 2010; He et al., 2012; Bröker-Lai et al., 2017). These facts suggest a putative link for TRPC conductances to serve as a potent mechanism that could modulate neurotransmitters and excitability in brain via metabotropic receptors, similar to the regulatory control of $\mathrm{M}$ channels. Interestingly, TRPC channel opening is also facilitated by depletion of intracellular $\mathrm{Ca}^{2+}$ stores (Boulay et al., 1999; see Discussion). Therefore, we hypothesized TRPC channel contribution to the mAChR-induced hyperexcitability of DGGCs. Indeed, in the presence of saturating concentrations of TRPC4/5 blockers (M084 and ML204, 10 MM; Miller et al., 2011; Zhu et al., 2015), increases in $\left[\mathrm{Ca}^{2+}\right]_{\mathrm{i}}$ by muscarinic stimulation were mostly but not completely blunted, again, as detected by calcium-green 1 emission (maximum 1.61 \pm 0.21-fold; Fig. 9A,B). To further investigate whether activation of TRPC channels is the mechanistic basis for the muscarinic increase in DGGC excitability, we performed parallel current-clamp recordings as before, comparing the muscarinic response in the presence or absence of the TRPC4/5 blocker M084 (10 $\mu \mathrm{M})$. In this series of experiments, $\mathrm{M}_{1} \mathrm{R}$ stimulation with 77-LH-28-1 (3 $\left.\mu \mathrm{M}\right)$ again significantly increased the action potential firing rate (Fig. 9D). However, under conditions of TRPC4/5 channel blockade, bath-application of $M_{1} R$ agonist did not increase the firing rate of action potentials (Fig. $9 D$ and Fig. 9-1, available at https://doi.org/10.1523/ JNEUROSCI.1781-18.2018.f9-1), nor was there a significant shift in the action potential threshold (M084 only: $-45.4 \pm 1.3 \mathrm{mV}$, M084 + 77-LH-28-1: $-46.1 \pm 1.5 \mathrm{mV}, t_{(14)}=0.35, p=0.73, n=$ 8 cells) or the average voltage floor across the range of voltages tested (Fig. 9E). However, blockade of TRPC channels did not 

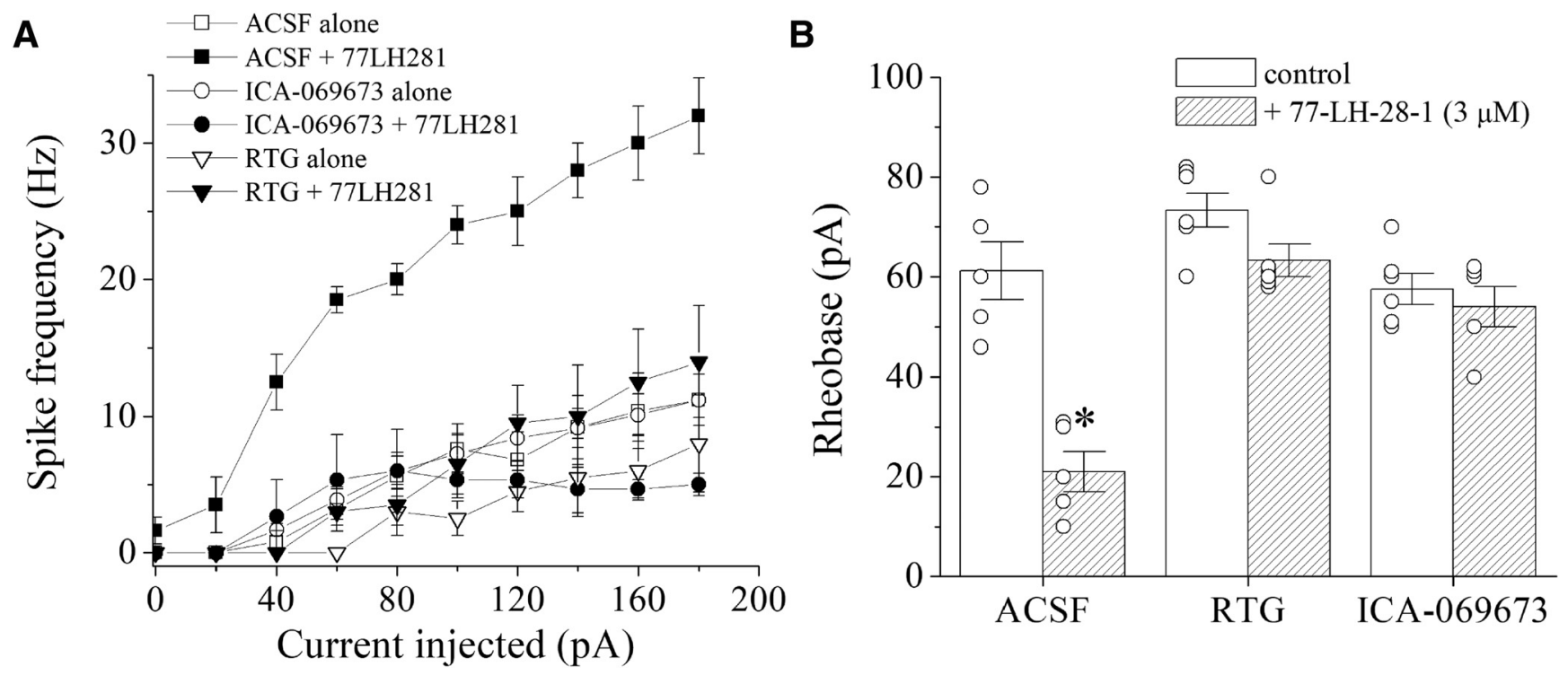

Figure 8. Pretreatment with M-channel openers prevents mAChR-induced hyperexcitability in DGGCs. A, Preapplication of either RTG or ICA-069673 ablated increases to DGGC spike frequency due to muscarinic stimulation by $3 \mu \mathrm{m}$ 77-LH-28-1 in the slice. $B$, Summarized current amplitudes required to evoke a single action potential (rheobase) in current-clamp recordings of DGGCs. Control condition indicates rheobase in the presence of either ACSF or M-channel opener application before muscarinic stimulation (white bars) compared with 10 min after application of 77-LH-28-1 (striped bars). ${ }^{*} p<0.05$ versus control; $n=7-10$ cells per group.

prevent the enhancement of $I_{M}$ amplitude by $M_{1}$ R stimulation. With TRPC4/5 channels blocked, $\mathrm{M}_{1} \mathrm{R}$ stimulation ( $3 \mu \mathrm{M}$ 77-LH28-1) resulted in a $1.83 \pm 0.14$-fold enhancement of $I_{\mathrm{M}}$ amplitude ( $n=6$ cells), which was similar to the enhancement observed in the absence of TRPC4/5 channel blockers (1.92 \pm 0.10 -fold). Analysis of AP properties during current injection with TRPC4/5 channels blocked revealed increases in the decay time constant of the AHPs induced by $\mathrm{M}_{1} \mathrm{R}$ stimulation (14.8 \pm 0.6 vs $17.1 \pm 0.8 \mathrm{~ms}, t_{(10)}=2.30, p=0.044, n=6$ cells) and in the mean area of the AHPs $\left(197 \pm 11\right.$ vs $265 \pm 22 \mathrm{~ms}^{*} \mathrm{mV}, t_{(10)}=$ 2.76, $p=0.02$ ), again, consistent with $\mathrm{M}_{1} \mathrm{R}$-mediated potentiation of $I_{\mathrm{M}}$ (Fig. 9-1, available at https://doi.org/10.1523/ JNEUROSCI.1781-18.2018.f9-1). However, with TRPC4/5 channels blocked, stimulation of $M_{1}$ Rs had no significant effect on either parameter at each value of injected current, consistent with no change to excitability under those conditions (Fig. 9E). The mechanistic reasons for this and their implications are elaborated on in the Discussion. We wondered whether there were microdomain-localized $\mathrm{Ca}^{2+}$ signals mediated by $\mathrm{IP}_{3} \mathrm{Rs}$ driving stimulation of $\mathrm{PIP}_{2}$ synthesis, as has been proposed in sympathetic ganglia (Delmas and Brown, 2002; Winks et al., 2005; Zaika et al., 2007). However, inclusion of xestospongin $\mathrm{C}(10 \mu \mathrm{M})$ in the pipette, as before, retained $\mathrm{M}_{1} \mathrm{R}$-mediated enhancement of $I_{\mathrm{M}}$ (1.67 \pm 0.14 -fold, $n=8$ cells).

Our findings are consistent with our hypothesis of TRPC4/5 (likely coupled with TRPC1) activation downstream of activation of PLC and $\mathrm{PIP}_{2}$ hydrolysis, mediating at least most of the increased excitability of DGGCs upon muscarinic stimulation that has been observed by us and by others. We note here that such stimulatory input must be quite strong because it opposes and clearly overwhelms the decrease in excitability that should otherwise occur upon enhancement of $I_{\mathrm{M}}$. Feedback rises in $\left[\mathrm{Ca}^{2+}\right]_{\mathrm{i}}$ corroborate the likelihood of this scenario (Ordaz et al., 2005). However, the contribution of PLC-produced diacylglycerol (DAG) in particular remains unclear given previous evidence of inactivation of TRPC4/5-containing channels by DAG (Venkatachalam et al., 2003). With $\mathrm{PIP}_{2}$ synthesis increased by several- fold upon muscarinic stimulation, production of DAG and its density in the membrane should correspondingly increase as well. The TRPC4/5-activated augmentation of the excitatory drive of DGGCs would thus be the result of the combinatorial actions of $\mathrm{M}_{1} \mathrm{R}$-mediated stimulation of $\mathrm{PIP}_{2}$ synthesis, amplified PLC-mediated $\mathrm{PIP}_{2}$ hydrolysis, release of $\left[\mathrm{Ca}^{2+}\right]_{\mathrm{i}}$, and subsequent feedforward amplification of TRPC channels (Fowler et al., 2007; see Discussion).

The hyperexcitability that we ascribe to activation of TRPC4/5 channels by $M_{1} R$ stimulation in DGGCs led us to wonder whether TRPC4/5 channels could be key regulators of the spread of epileptogenic seizures. Prior evidence suggests the involvement of TRPC family channels in the control of excitability in other distinct neurons in the hippocampus (Strübing et al., 2001; Michel et al., 2005; Tai et al., 2011; Bröker-Lai et al., 2017). Moreover, TRPC4/5 blockade has been demonstrated to suppress depression-like and anxiety behaviors of mice in vivo (Yang et al., 2015), similar to profiles of several classes of anticonvulsant drugs with mechanisms of action that target neuronal inhibition. Our $\mathrm{Ca}^{2+}$-imaging experiments showed that TRPC4/5 blockade ablates most of the $\mathrm{M}_{1} \mathrm{R}$-induced rise in $\left[\mathrm{Ca}^{2+}\right]_{\mathrm{i}}$, suggesting that global TRPC4/5 blockade in the brain might preclude seizures mediated by undue $\mathrm{Ca}^{2+}$ influx. To test this hypothesis in vivo, we investigated TRPC4/5 channel block in the prevention of chemoconvulsant-induced seizures in mice using the well established pilocarpine seizure model (Fig. 9F). This model has the advantage of widespread muscarinic receptor stimulation as the trigger for spreading hyperexcitability. After administration of scopolamine $(1 \mathrm{mg} / \mathrm{kg})$, control mice were pretreated with saline vehicle and then were administered pilocarpine $(280 \mathrm{mg} / \mathrm{kg}) 30$ min later. All control animals developed strong progression of seizures that resulted in status epilepticus (mean maximum Racine seizure stage: $4.8 \pm 0.2$ ). However, littermates that were treated with the TRPC4/5 antagonist M084 (10 mg/kg) $30 \mathrm{~min}$ before the same dose of pilocarpine demonstrated significantly reduced seizure behavior (mean maximum Racine seizure stage: $1.1 \pm 0.5)$ and status epilepticus was not observed in any animal 
A

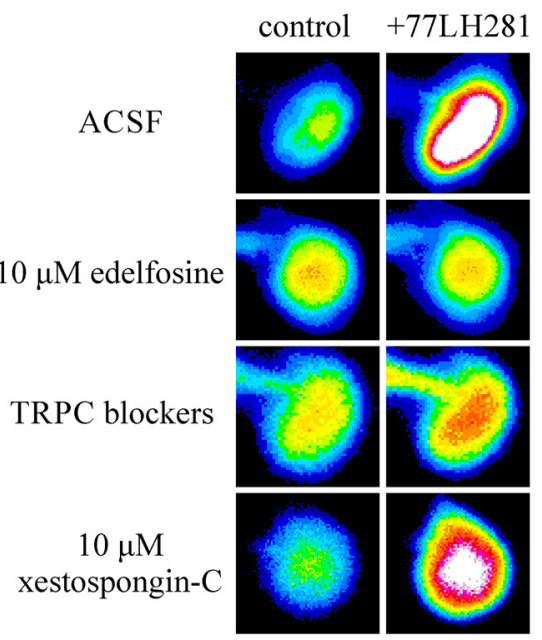

C

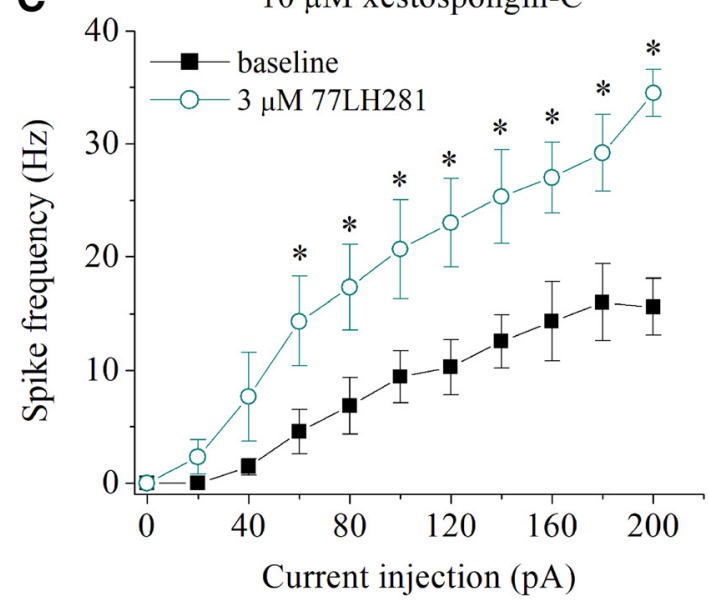

$\mathbf{E}$

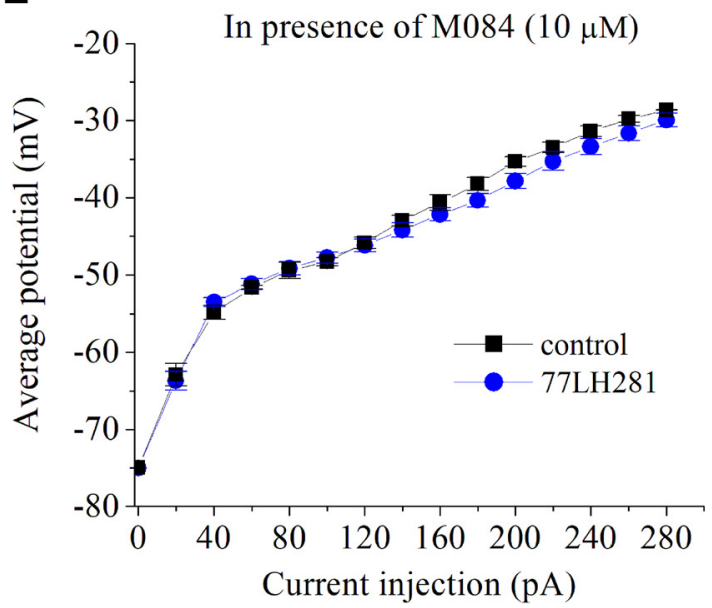

B

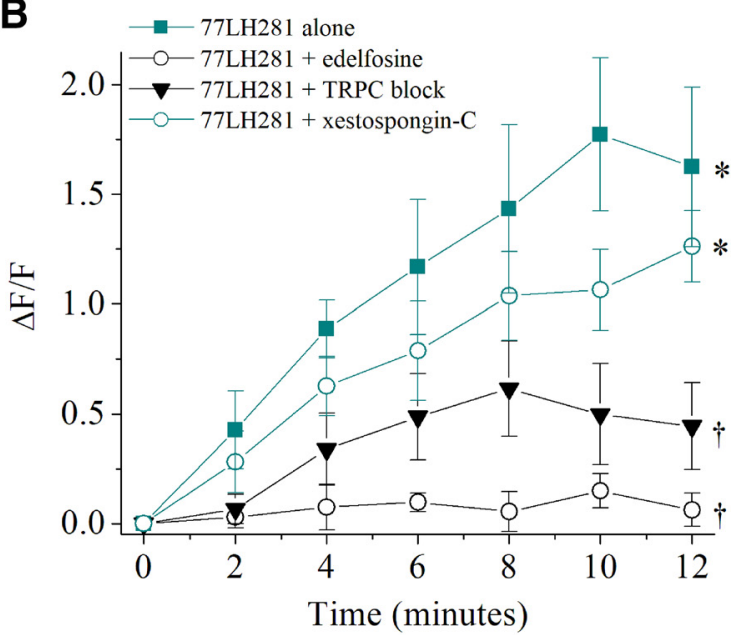

D

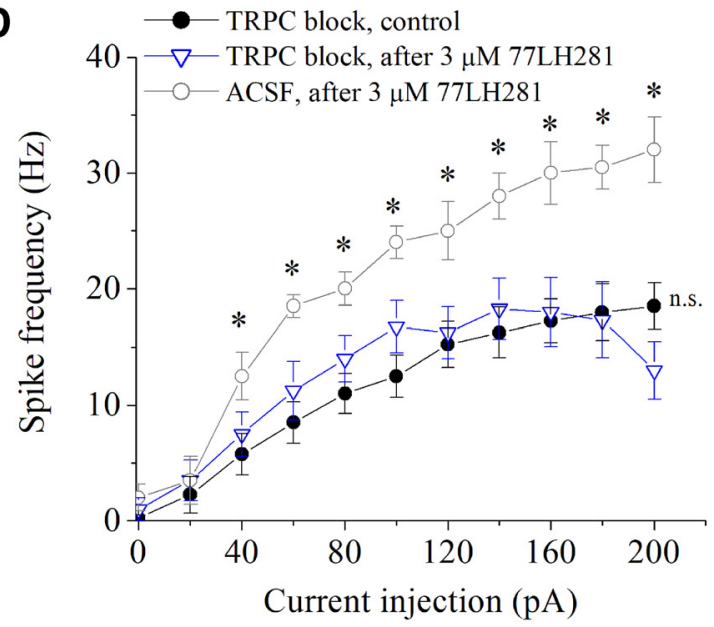

$\mathbf{F}$

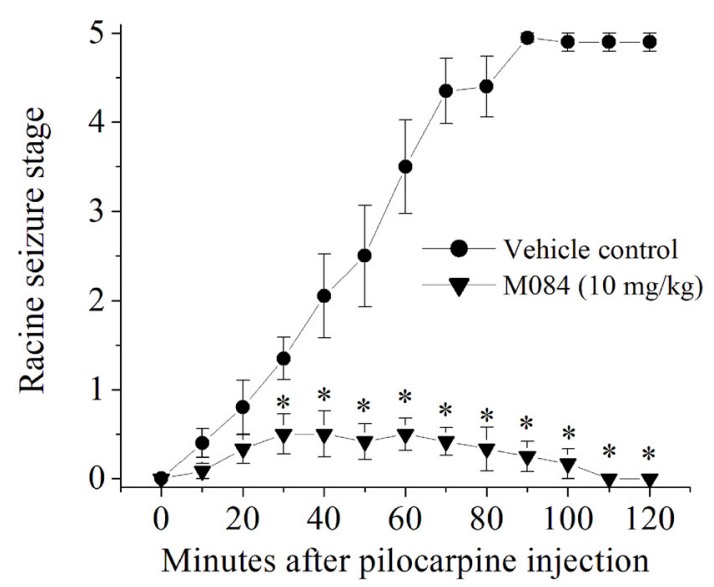

Figure 9. Muscarinic stimulation of DGGCs induces intracellular rises in $\left[\mathrm{Ca}^{2+}\right]$ that is mostly due to TRPC4/5 channels, which underlie $\mathrm{M}_{1} \mathrm{R}$-induced hyperexcitability of DGGCs. $\boldsymbol{A}$, Calcium green-1 fluorescence before and after bath-application of 77-LH-28-1 (3 $\mu \mathrm{M}$ ) alone or in the presence of edelfosine (10 $\mu \mathrm{M})$, the TRPC channel blockers M084 and ML204 (10 $\mu \mathrm{M})$, or with the IP $\mathrm{R}$ blocker, xestospongin- $C(10 \mu \mathrm{M})$, in the internal pipette solution. Images depict 16-color pseudocolor heat maps of fluorescence intensity. $\boldsymbol{B}$, Summarized changes in fluorescence intensity over 0 12 min after perfusion of slices with 77-LH-28-1. $n=5-7$ cells per group. ${ }^{*} p<0.05$ versus 77 -LH-28-1 + edelfosine; $t p<0.05$ versus 77 -LH-28- 1 alone. C, Summarized evoked action potential frequencies before (filled squares) and after application of 77-LH-28-1 (open circles) in the presence of xestospongin C. D, Summarized evoked action potential frequencies during TRPC blockade with M084 and ML204 before (filled circles) and after bath-application of 77-LH-28-1 (open triangles) * $p<0.05$ versus TRPC block, control. $\boldsymbol{E}$, Plotted are summarized membrane potential values (voltage floor) in the presence of the TRPC $4 / 5$ channel antagonist M084 $(10 \mu \mathrm{M})$. There were no significant differences in any values between those obtained in control ACSF and during application

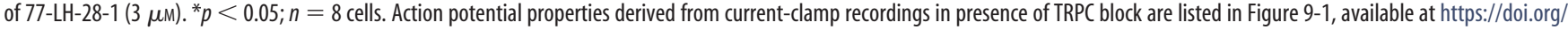
10.1523/JNEUROSCI.1781-18.2018.f9-1.F, In vivo pretreatment with TRPC channel antagonists confers protection from pilocarpine-induced chemoconvuslant seizures. Plots summarize the Racine seizure stage progression of adult mice that were treated with vehicle or M084 $(10 \mathrm{mg} / \mathrm{kg})$ to block TRPC $4 / 5$ channels $30 \mathrm{~min}$ before challenge with pilocarpine $(280 \mathrm{mg} / \mathrm{kg})$. ${ }^{*} p<0.05$ versus vehicle control; $n=8$ mice per group. 
( $n=8$ mice per group; Fig. $9 F$ ). Because TRPC4/5 blockade suppressed chemoconvulsant seizures throughout the brain in this assay, these results are suggestive of a widespread role of TRPC channels in epileptogenesis (Zheng, 2017). Therefore, TRPC channel inhibitors may represent a mode of anticonvulsant therapeutic control of seizures and retardation of the development of epilepsy disease from a variety of causes.

\section{Discussion}

The modulation of M-type $\mathrm{K}^{+}$channels by $\mathrm{G}_{\mathrm{q} / 11}$-coupled mAChRs is a key regulatory mechanism of excitability, discharge properties, and circuit function of the hippocampus (Gamper and Shapiro, 2015). However, neither the precise contribution of $I_{\mathrm{M}}$ to the threshold $\mathrm{K}^{+}$current nor the effects of $\mathrm{G}_{\mathrm{q} / 11}$-coupled mAChR stimulation on $I_{\mathrm{M}}$ has been comparatively described among hippocampal principal neurons. Our whole-cell recordings afforded excellent voltage control of the soma and AIS of the neurons and we were able to take advantage of the signature voltage dependence, pharmacology, and kinetics of $\mathrm{M}$ channels to isolate $I_{\mathrm{M}}$ for analysis. Moreover, neuron-specific knock-down of KCNQ2 via transgenic mice allowed us to offer conclusive evidence for the identity of the $\mathrm{K}^{+}$channels under investigation.

We focused on DGGCs and CA1 pyramidal neurons to probe mAChR-related neuromodulation of the hippocampus. Although stimulation of $M_{1}$ Rs in DGGCs increased excitability in accordance with previous reports (Tzingounis and Nicoll, 2008; Mateos-Aparicio et al., 2014; Soh et al., 2014; Martinello et al., 2015), the effect on $I_{M}$ was a robust potentiation of conductance, rather than its depression, suggesting $\mathrm{mAChR}$-mediated stimulation of $\mathrm{PIP}_{2}$ synthesis as the most likely mechanism. To support this hypothesis, we investigated the well known sensitivity of GIRK channels to PIP $_{2}$ abundance (Huang et al., 1998; Hilgemann et al., 2007) and, indeed, $I_{\mathrm{GIRK}}$ was increased in a closely parallel manner as $I_{\mathrm{M}}$ in the same cells. We did not observe a transient decrease in $I_{\mathrm{M}}$, such as due to $\mathrm{Ca}^{2+} /$ calmodulin action, before the stimulation of $\mathrm{PIP}_{2}$ synthesis that we ascribe to $I_{\mathrm{M}}$ augmentation. In CA1 pyramidal cells, $\mathrm{Ca}^{2+}$ influx through L-type voltage-gated $\mathrm{Ca}^{2+}$ channels was shown to potentiate $I_{\mathrm{M}}$ (Wu et al., 2008). However, we demonstrate in DGGCs that the enhancement of $I_{\mathrm{M}}$ occurs independently of VGCC currents (Fig. $2 G$ ). Loew and colleagues previously showed that, in the case of bradykinin-evoked action on $I_{M}$ in neuroblastoma cells, stimulation of PIP ${ }_{2}$ synthesis occurs (Xu and Loew, 2003; Xu et al., 2003) and $I_{\mathrm{M}}$ increases (Xu and Loew, 2003) before suppression of current occurs. Recent evidence suggests that the plasma membrane pools of $\mathrm{PI}(4) \mathrm{P}$ and $\mathrm{PIP}_{2}$ may be independently regulated by PLC-dependent, G-protein-coupled receptor stimulation and that the replenishment of $\mathrm{PIP}_{2}$ does not underlie receptorstimulated depletion of PI(4)P from the plasma membrane (de Rubio et al., 2018). In lymphocytes, in which PLC-directed stimulation of $\mathrm{PIP}_{2}$ synthesis has long been known to occur (Lassing and Lindberg, 1990; Racaud-Sultan et al., 1993), the increase of $\mathrm{PIP}_{2}$ abundance is due to a positive feedback amplification loop of hydrolysis followed by PI(4)P-5K-dependent synthesis (Xu et al., 2017). We posit that the accumulation of $\mathrm{PIP}_{2}$ we observed in DGGCs may proceed via a similar mechanism, given that $\mathrm{PI}(4) \mathrm{P}-5 \mathrm{~K}$ inhibition eliminated the PLC-driven enhancement of $I_{\mathrm{M}}$ (Fig. 3).

Given that an enhancement in $I_{\mathrm{M}}$ should lead to a decrease in excitability, the fact that we observed a muscarinic-induced increase in excitability led us to investigate whether an excitatory current might be concomitantly activated downstream of $M_{1} R$ stimulation and we hypothesized significant contribution of
TRPC channels as the underlying target. In stark contrast, stimulation of $\mathrm{M}_{1}$ Rs in CA1 pyramidal neurons depressed $I_{\mathrm{M}}$ similar to the effect in peripheral ganglia, suggesting the absence of concomitant stimulation of $\mathrm{PIP}_{2}$ synthesis and consequential $\mathrm{PIP}_{2}$ depletion in those neurons (Fig. $2 H$ ). Therefore, the $G_{\mathrm{q} / 11^{-}}$ coupled mAChR, PLC-dependent gating of M channels, which is present in both types of hippocampal neurons, are modulated in dramatically distinct ways. Our results emphasize the stark contrast in muscarinic signaling between DG and CA1 that have strong influences on neuronal discharge properties and hippocampal function.

M-channel modulation has been most prevalently studied in sympathetic neurons. There, receptor-specific stimulation of $\mathrm{PIP}_{2}$ synthesis has been shown to depend on a parallel receptorspecific rise in $\left[\mathrm{Ca}^{2+}\right]_{\mathrm{i}}$ from $\mathrm{IP}_{3}$-gated stores (Gamper et al., 2004; Winks et al., 2005; Zaika et al., 2011). $\mathrm{Ca}^{2+}$ imaging of DGGCs in brain slices revealed a strong increase in $\left[\mathrm{Ca}^{2+}\right]_{\mathrm{i}}$ that persisted during maintained $M_{1} R$ agonist exposure (Fig. 9) even after the agonist was washed off. What is the source of the relevant $\mathrm{Ca}^{2+}$ signal? In most excitable cells, this is a complex issue because cytoplasmic rises in $\left[\mathrm{Ca}^{2+}\right]$ can be due to opening of $\mathrm{IP}_{3} \mathrm{Rs}$ or ryanodine receptors and influx of $\mathrm{Ca}^{2+}$ through several different types of $\mathrm{Ca}^{2+}$-permeable channels, including TRP-family types (Ramsey et al., 2006; Prakriya and Lewis, 2015). Moreover, these $\mathrm{Ca}^{2+}$ sources are typically not fully independent because $\mathrm{Ca}^{2+}$ ions originating from one source have been shown to influence the opening of the others. $\mathrm{Ca}^{2+}$-induced $\mathrm{Ca}^{2+}$ release is closely involved with ryanodine receptors, which are critical to memory formation in hippocampus (Baker et al., 2013). Here, we found stimulation of $\mathrm{M}_{1}$ Rs in DGGCs to induce a prolonged rise in $\left[\mathrm{Ca}^{2+}\right]_{\mathrm{i}}$ that was only slightly reduced by blockade of $\mathrm{IP}_{3} \mathrm{Rs}$ and strongly attenuated by blockade of TRPC channels (Fig. 7B). In sympathetic and sensory neurons, receptor-induced stimulation of $\mathrm{PIP}_{2}$ synthesis is entirely dependent upon $\mathrm{IP}_{3} \mathrm{Rs}$, as are the profound $\left[\mathrm{Ca}^{2+}\right]_{\mathrm{i}}$ rises in spines of cerebellar Purkinje neurons by stimulation of mGluRs (Finch and Augustine, 1998; Takechi et al., 1998; Loew, 2007). We found that, for DGGCs, the greater fraction of the $\mathrm{M}_{1} \mathrm{R}$-mediated $\left[\mathrm{Ca}^{2+}\right]_{i}$ rises are due to TRPC channels, with a much smaller fraction due to $\mathrm{IP}_{3} \mathrm{Rs}$, yet blockade of neither affected potentiation of $I_{\mathrm{M}}$. Because the rate-limiting step in $\mathrm{PIP}_{2}$ synthesis is PI 4-kinase activity and stimulation of PI 4-kinase is closely associated with intracellular $\mathrm{Ca}^{2+}$ signals (Balla et al., 2008), we are reluctant to exclude $\mathrm{Ca}^{2+}$ signaling from this process in DGGCs. In addition, activation of protein kinase C recruited by A-kinase anchoring protein 79/150 accessory to M-channels (Hoshi et al., 2003, 2005; Zhang et al., 2011; Kosenko et al., 2012) was not tested in the neurons. From the data in this study, we demonstrate that stimulation of $\mathrm{PIP}_{2}$ synthesis must be involved, because blockade of PI(4)P 5-kinases converted enhancement of $I_{\mathrm{M}}$ to its suppression (Figs. 3, 6).

We found that TRPC4/5 channel blockade abolished the increase in neuronal excitability by muscarinic agonists, yet excitability did not decrease with TRPC channels blocked and $I_{\mathrm{M}}$ enhanced. However, some thought explains this. Due to the relatively high input resistance of DGGCs, their resting potential is normally quite negative to the threshold for activation of $\mathrm{M}$ channels and their basal rate of firing is low. Additionally, the activation kinetics of $\mathrm{M}$ channels are an order of magnitude slower than the time scale of an action potential (Gamper and Shapiro, 2015). Therefore, enhancement of $I_{\mathrm{M}}$ by stimulation of $\mathrm{PIP}_{2}$ synthesis cannot alter excitability until excitatory stimulation becomes strong enough to foster rapid firing and greater membrane depolarization during more rapid action potential firing, resulting in 
greater opening of M-channels, promoting two opposing drives on excitability. A decrease in excitability is favored, based on the laws of Goldman-Hodgkin-Katz; that is, a greater $\mathrm{K}^{+}$conductance opposing depolarization away from $E_{\mathrm{K}}$. However, the strong correlation between $I_{\mathrm{M}}$ amplitudes and the AHP area evident in our data indicate that the contribution of $\mathrm{M}$ channels to AHPs in DGGCs is particularly substantial. Therefore, sustained firing of action potentials in DGGCs produces a strong depolarization of the average potential (voltage floor; Fig. 5) facilitated by the high impedance of DGGCs, inducing partial depolarization block via $\mathrm{Na}^{+}$channel inactivation. The $\mathrm{M}$ channel-mediated augmentation in AHP area thus promotes greater excitability from relief of accumulated inactivation of $\mathrm{Na}^{+}$channels. This paradoxical effect is reminiscent of the results of Vervaeke et al. (2006), studying the relationship of $I_{\mathrm{M}}$ and excitability in CA1 pyramidal neurons, in which they mimicked a depolarized voltage floor produced by sustained action potentials with modestly elevated $\left[\mathrm{K}^{+}\right]_{\mathrm{o}}$ and found relief of depolarization block by greater $I_{\mathrm{M}}$ activation to increase excitability. Our analysis shows that, with both M-channels and TRPC4/5 channels activated, the resulting voltage floor is significantly depolarized (Fig. $5 F$ ) with overall greater excitability as the result. However, with TRPC4/5 channels blocked, there was no net change in the voltage floor (Fig. 9E) even though $I_{\mathrm{M}}$ is still enhanced. Furthermore, when M-channel openers were applied to negatively shift the voltage dependence of KCNQ2-containing channels, $I_{M}$ enhancement substantially counteracted the $\mathrm{M}_{1} \mathrm{R}$-induced cascade of excitability in DGGCs (Fig. 8). Therefore, the two opposing actions of $I_{M}$ on excitability, which clearly depend on the degree of excitation of the neurons, are likely to closely balance themselves out in DGGCs.

A previous study (Martinello et al., 2015) examined cholinergic/muscarinic actions of DGGCs both from stimulation of cholinergic fibers in the slice and from stimulation of $\mathrm{mAChRs}$ by exogenous agonists, the latter of which we do here. Their study and ours both demonstrate a pronounced increase in excitability of DGGCs subsequent to stimulation of $\mathrm{G}_{\mathrm{q} / 11}$-coupled $\mathrm{M}_{1} \mathrm{Rs}$. We also find a strong increase in excitability if $\mathrm{M}$ channels are totally blocked by XE-991, yielding concordant conclusions as to the critical role of $I_{\mathrm{M}}$ in DGGC firing. However, our results strikingly diverge in that we demonstrate convincing evidence that alteration in $I_{M}$ from $\mathrm{M}_{1} \mathrm{R}$ stimulation depends on $\mathrm{PIP}_{2}$ abundance and, moreover, we find that $I_{\mathrm{M}}$ is enhanced by $\mathrm{M}_{1} \mathrm{R}$ agonists as opposed to $\mathrm{M}$ channels being inhibited. We replicated our findings in both mouse and rat DGGCs, observing equal enhancement of $I_{\mathrm{M}}$ in both at room temperature. We also performed all of our voltage-clamp experiments under whole-cell mode with much more favorable access resistance for the required biophysical analysis of the $\mathrm{K}^{+}$currents (Kim et al., 2016a,b). Martinello and colleagues found T-type $\mathrm{Ca}^{2+}$ channels to be involved in $\mathrm{mAChR}$ modulation of DGGCs, but we did not observe any effect of T-type channels on the enhancement of $I_{M}$ (Fig. 2G).

Our data point to TRPC4/5 channel activation as the source of the observed persistent rises in $\left[\mathrm{Ca}^{2+}\right]_{i}$ upon stimulation of $\mathrm{mAChRs}$ rather than any type of VGCCs. The evidence includes that somatic $\mathrm{Ca}^{2+}$ influx occurred upon $\mathrm{M}_{1} \mathrm{R}$ stimulation during voltage clamp of DGGCs at $-75 \mathrm{mV}$; however, we realize that, under those conditions, we are unable to effectively voltage clamp the distal axon as well. The bulk of the $\left[\mathrm{Ca}^{2+}\right]_{i}$ rise that we observed was ablated by blocking TRPC4/5 channels. TRPC channels are regulated by the very downstream products of PLC activation subsequent to $\mathrm{G}_{\mathrm{q} / 11}-\mathrm{mAChR}$ stimulation and are therefore a plausible underlying source of both the pronounced increase in neuronal excitability and most of the increase in $\left[\mathrm{Ca}^{2+}\right]_{\mathrm{i}}$. It is important to note that the time course of changes in $I_{\mathrm{M}}$ did not include a transient suppression of $I_{\mathrm{M}}$ before its enhancement (Fig. 2), suggesting either a lack of close proximity of $M_{1}$ Rs and $M$ channels, as opposed to their intimate association in sympathetic ganglia (Zhang et al., 2016), or an abundant pool of $\mathrm{PIP}_{2}$ in DGGCs that is insulated from any initial PLC-induced $\mathrm{PIP}_{2}$ hydrolysis. We have yet to do advanced microscopy and microdomain analysis of the subcellular localization of these signaling molecules required to answer such questions.

The exquisite, multimodal neuromodulation by $M_{1} R s$ in DGGCs that we report here highlights the pivotal role of the DG as a filter for the hippocampus in controlling excitability. An equally interesting line of investigation would be to determine whether pathophysiological cholinergic challenges to the DG are sufficient to promote epileptogenic propagation of seizures throughout the brain (Sloviter et al., 2012), also mediated by regulation of TRPC channel activation. Finally, these regulatory cascades may be instrumental to disorders of hyperexcitability or hypoexcitability, such as epilepsy or cognitive dysfunction.

\section{References}

Alexander GM, Rogan SC, Abbas AI, Armbruster BN, Pei Y, Allen JA, Nonneman RJ, Hartmann J, Moy SS, Nicolelis MA, McNamara JO, Roth BL (2009) Remote control of neuronal activity in transgenic mice expressing evolved G protein-coupled receptors. Neuron 63:27-39. CrossRef Medline

Baker KD, Edwards TM, Rickard NS (2013) The role of intracellular calcium stores in synaptic plasticity and memory consolidation. Neurosci Biobehav Rev 37:1211-1239. CrossRef Medline

Bal M, Zhang J, Hernandez CC, Zaika O, Shapiro MS (2010) $\mathrm{Ca}^{2+} /$ calmodulin disrupts AKAP79/150 interactions with KCNQ (M-type) $\mathrm{K}^{+}$channels. J Neurosci 30:2311-2323. CrossRef Medline

Balla A, Kim YJ, Varnai P, Szentpetery Z, Knight Z, Shokat KM, Balla T (2008) Maintenance of hormone-sensitive phosphoinositide pools in the plasma membrane requires phosphatidylionsitol 4-kinase IIIalpha. Mol Biol Cell 19:711-721. CrossRef Medline

Battefeld A, Tram BT, Gavrilis J, Cooper EC, Kole MH (2014) Heteromeric $\mathrm{K}_{\mathrm{v}} 7.2 / 7.3$ channels differentially regulate action potential initiation and conduction in neocortical myelinated axons. J Neurosci 34:3719-3732. CrossRef Medline

Beech DJ, Bernheim L, Mathie A, Hille B (1991) Intracellular $\mathrm{Ca}^{2+}$ buffers disrupt muscarinic suppression of $\mathrm{Ca}^{2+}$ current and $\mathrm{M}$ currentin rat sympathetic neurons. Proc Natl Acad Sci U S A 88:652-656. CrossRef Medline

Bergson P, Lipkind G, Lee SP, Duban ME, Hanck DA (2011) Verapamil block of T-type calcium channels. Mol Pharmacol 79:411-419. CrossRef Medline

Bernheim L, Beech DJ, Hille B (1991) A diffusible second messenger mediates one of the pathways coupling receptors to calcium channels in rat sympathetic neurons. Neuron 6:859-867. CrossRef Medline

Biervert C, Schroeder BC, Kubisch C, Berkovic SF, Propping P, Jentsch TJ, Steinlein OK (1998) A potassium channel mutation in neonatal human epilepsy. Science 279:403-406. CrossRef Medline

Boulay G, Brown DM, Qin N, Jiang M, Dietrich A, Zhu MX, Chen Z, Birnbaumer M, Mikoshiba K, Birnbaumer L (1999) Modulation of $\mathrm{Ca}^{2+}$ entry by polypeptides of the inositol 1,4,5-triphosphate receptor $\left(\mathrm{IP}_{3} \mathrm{R}\right)$ that bind transient receptor potential (TRP): evidence for roles of TRP and IP3R in store depletion-activated $\mathrm{Ca}^{2+}$ entry. Proc Natl Acad Sci U S A 96:14955-14960. CrossRef Medline

Bröker-Lai J, Kollewe A, Schindeldecker B, Pohle J, Nguyen Chi V, Mathar I, Guzman R, Schwarz Y, Lai A, Weißgerber P, Schwegler H, Dietrich A, Both M, Sprengel R, Draguhn A, Köhr G, Fakler B, Flockerzi V, Bruns D, Freichel M (2017) Heteromeric channels formed by TRPC1, TRPC4 and TRPC5 define hippocampal synaptic transmission and working memory. EMBO J 36:2770-2789. CrossRef Medline

Brown DA, Adams PR (1980) Muscarinic suppression of a novel voltagesensitive $\mathrm{K}^{+}$current in a vertebrate neurone. Nature 283:673-676. CrossRef Medline 
Brown DA, Passmore GM (2009) Neural KCNQ (Kv7) channels. Br J Pharmacol 156:1185-1195. CrossRef Medline

Brown SA, Morgan F, Watras J, Loew LM (2008) Analysis of phosphatidylinositol 4,5-bisphosphate signaling in cerebellar purkinje spines. Biophys J 95:1795-1812. CrossRef Medline

Bymaster FP, Carter PA, Yamada M, Gomeza J, Wess J, Hamilton SE, Nathanson NM, McKinzie DL, Felder CC (2003) Role of specific muscarinic receptor subtypes in cholinergic parasympathomimetic responses, in vivo phosphoinositide hydrolysis, and pilocarpine-induced seizure activity. Eur J Neurosci 17:1403-1410. CrossRef Medline

Carver CM, Wu X, Gangisetty O, Reddy DS (2014) Perimenstrual-like hormonal regulation of extrasynaptic $\delta$-containing GABAA receptors mediating tonic inhibition and neurosteroid sensitivity. J Neurosci 34: 14181-14197. CrossRef Medline

Chiang PH, Yeh WC, Lee CT, Weng JY, Huang YY, Lien CC (2010) $\mathrm{M}_{1}$-like muscarinic acetylcholine receptors regulate fast-spiking interneuron excitability in rat dentate gyrus. Neuroscience 169:39-51. CrossRef Medline

Chung HJ, Jan YN, Jan LY (2006a) Polarized axonal surface expression of neuronal KCNQ channels is mediated by multiple signals in the KCNQ2 and KCNQ3 C-terminal domains. Proc Natl Acad Sci U S A 103:88708875. CrossRef Medline

Chung YH, Sun Ahn H, Kim D, Hoon Shin D, Su Kim S, Yong Kim K, Bok Lee W, Ik Cha C (2006b) Immunohistochemical study on the distribution of TRPC channels in the rat hippocampus. Brain Res 1085:132-137. CrossRef Medline

Constanti A, Brown DA (1981) M-currents in voltage-clamped mammalian sympathetic neurones. Neurosci Lett 24:289-294. CrossRef Medline

Cooper EC, Jan LY (2003) M-channels: neurological diseases, neuromodulation, and drug development. Arch Neurol 60:496-500. CrossRef Medline

Cooper EC, Harrington E, Jan YN, Jan LY (2001) M channel KCNQ2 subunits are localized to key sites for control of neuronal network oscillations and synchronization in mouse brain. J Neurosci 21:9529-9540. CrossRef Medline

Coulter DA, Carlson GC (2007) Functional regulation of the dentate gyrus by GABA-mediated inhibition. Prog Brain Res 163:235-243. CrossRef Medline

Cui ED, Strowbridge BW (2018) Modulation of ether-à-go-go related gene (ERG) current governs intrinsic persistent activity in rodent neocortical pyramidal cells. J Neurosci 38:423-440. CrossRef Medline

Delmas P, Brown DA (2002) Junctional signaling microdomains: bridging the gap between the neuronal cell surface and $\mathrm{Ca}^{2+}$ stores. Neuron 36: 787-790. CrossRef Medline

Dengler CG, Yue C, Takano H, Coulter DA (2017) Massively augmented hippocampal dentate gyrus granule cell activation accompanies epilepsy development. Sci Rep 7:42090. CrossRef Medline

de Rubio RG, Ransom RF, Malik S, Yule DI, Anantharam A, Smrcka AV (2018) Phosphatidylinositol 4-phosphate is a major source of GPCRstimulated phosphoinosidtide production. Sci Signal 11:eaan1210. CrossRef Medline

Di Paolo G, Moskowitz HS, Gipson K, Wenk MR, Voronov S, Obayashi M, Flavell R, Fitzsimonds RM, Ryan TA, De Camilli P (2004) Impaired PtdIns(4,5)P2 synthesis in nerve terminals produces defects in synaptic vesicle trafficking. Nature 431:415-422. CrossRef Medline

Falkenburger BH, Jensen JB, Hille B (2010) Kinetics of PIP $_{2}$ metabolism and KCNQ2/3 channel regulation studied with a voltage-sensitive phosphatase in living cells. J Gen Physiol 135:99-114. CrossRef Medline

Fano S, Çalışkan G, Heinemann U (2012) Differential effects of blockade of ERG channels on gamma oscillations and excitability in rat hippocampal slices. Eur J Neurosci 36:3628-3635. CrossRef Medline

Fidzinski P, Korotkova T, Heidenreich M, Maier N, Schuetze S, Kobler O, Zuschratter W, Schmitz D, Ponomarenko A, Jentsch TJ (2015) KCNQ5 $\mathrm{K}^{+}$channels control hippocampal synaptic inhibition and fast network oscillations. Nat Commun 6:6254. CrossRef Medline

Finch EA, Augustine GJ (1998) Local calcium signalling by ionsitol-1,4,5trisphosphate in purkinje cell dendrites. Nature 396:753-756. CrossRef Medline

Fiszman ML, Barker JL, Jones SV (1991) Electrophysiological responses to muscarinic receptor stimulation in cultured hippocampal neurons. Brain Res 557:1-4. CrossRef Medline

Fowler MA, Sidiropoulou K, Ozkan ED, Phillips CW, Cooper DC (2007)
Corticolimbic expression of TRPC4 and TRPC5 channels in rodent brain. PLoS One 2:e573. CrossRef Medline

Gafni J, Munsch JA, Lam TH, Catlin MC, Costa LG, Molinski TF, Pessah IN (1997) Xestospongins: potent membrane permeable blockers of the inositol 1,4,5-trisphosphate receptors. Neuron 19:723-733. CrossRef Medline

Gamper N, Shapiro MS (2015) KCNQ channels. In: Handbook of ion channels, Ed 1 (Zheng J, Trudeau MC, eds), pp 275-306. Boca Raton, FL: CRC.

Gamper N, Stockand JD, Shapiro MS (2003) Subunit-specific modulation of KCNQ potassium channels by src tyrosine kinase. J Neurosci 23:84-95. CrossRef Medline

Gamper N, Reznikov V, Yamada Y, Yang J, Shapiro MS (2004) Phosphatidylinositol 4,5-bisphosphate signals underlie receptor-specific $G_{q / 11^{-}}$ mediated modulation of N-type $\mathrm{Ca}^{2+}$ channels. J Neurosci 24:10980-10992. CrossRef Medline

Gessner G, Heinemann SH (2003) Inhibition of hEAG1 and hERG1 potassium channels by clofilium and its tertiary analogue LY97241. Br J Pharmacol 138:161-171. CrossRef Medline

Glaaser IW, Slesinger PA (2017) Dual activation of neuronal G proteingated inwardly rectifying potassium (GIRK) channels by cholesterol and alcohol. Sci Rep 7:4592. CrossRef Medline

Greene DL, Hoshi N (2017) Modulation of Kv7 channels and excitability in the brain. Cell Mol Life Sci 74:495-508. CrossRef Medline

Gu N, Vervaeke K, Hu H, Storm JF (2005) Kv7/KCNQ/M and HCN/h, but not $\mathrm{K}_{\mathrm{Ca} 2+} / \mathrm{SK}$ channels, contribute to the somatic medium afterhyperpolarization and excitability control in CA1 hippocampal pyramidal cells. J Physiol 566:689-715. CrossRef Medline

Gustina AS, Trudeau MC (2009) A recombinant N-terminal domain fully restores deactivation gating in $\mathrm{N}$-truncated and long QT syndrome mutant hERG potassium channels. Proc Natl Acad Sci U S A 106:1308213087. CrossRef Medline

Hadley JK, Noda M, Selyanko AA, Wood IC, Abogadie FC, Brown DA (2000) Differential tetraethylammonium sensitivity of KCNQ1-4 potassium channels. Br J Pharamacol 129:413-415. CrossRef Medline

Hamilton SE, Loose MD, Qi M, Levey AI, Hille B, McKnight GS, Idzerda RL, Nathanson NM (1997) Disruption of the $\mathrm{m} 1$ receptor gene ablates muscarinic receptor-dependent $\mathrm{M}$ current regulation and seizure activity in mice. Proc Natl Acad Sci U S A 94:13311-13316. CrossRef Medline

He Z, Jia C, Feng S, Zhou K, Tai Y, Bai X, Wang Y (2012) TRPC5 channel is the mediator of neurotrophin-3 in regulating dendritic growth via CaMKII $\alpha$ in rat hippocampal neurons. J Neurosci 32:9383-9395. CrossRef Medline

Hernandez CC, Zaika O, Shapiro MS (2008a) A carboxy-terminal interhelix linker as the site of phosphatidylinositol 4,5-bisphosphate action on Kv7 (M-type) $\mathrm{K}^{+}$channels. J Gen Physiol 132:361-381. CrossRef Medline

Hernandez CC, Zaika O, Tolstykh GP, Shapiro MS (2008b) Regulation of neural KCNQ channels: signaling pathways, structural motifs and functional implications. J Physiol 586:1811-1821. CrossRef Medline

Hernandez CC, Falkenburger B, Shapiro MS (2009) Affinity for phosphatidylinositol 4,5-bisphosphate determines muscarinic agonist sensitivity of Kv7 K ${ }^{+}$channels. J Gen Physiol 134:437-448. CrossRef Medline

Hester MS, Danzer SC (2013) Accumulation of abnormal adult-generated hippocampal granule cells predicts seizure frequency and severity. J Neurosci 33:8926-8936. CrossRef Medline

Hilgemann DW (2007) Local PIP ${ }_{2}$ signals: when, where, and how? Pflugers Arch 455:55-67. CrossRef Medline

Horowitz LF, Hirdes W, Suh BC, Hilgemann DW, Mackie K, Hille B (2005) Phospholipase $\mathrm{C}$ in living cells: activation, inhibition, $\mathrm{Ca}^{2+}$ requirement, and regulation of M current. J Gen Physiol 126:243-262. CrossRef Medline

Hoshi N, Zhang JS, Omaki M, Takeuchi T, Yokoyama S, Wanaverbecq N, Langeberg LK, Yoneda Y, Scott JD, Brown DA, Higashida H (2003) AKAP150 signaling complex promotes suppression of the M-current by muscarinic agonists. Nat Neurosci 6:564-571. CrossRef Medline

Hoshi N, Langeberg LK, Scott JD (2005) Distinct enzyme combinations in AKAP signalling complexes permit functional diversity. Nat Cell Biol 7:1066-1073. CrossRef Medline

Hu H, Vervaeke K, Storm JF (2002) Two forms of electrical resonance at theta frequencies generated by $\mathrm{M}$-current, $\mathrm{H}$-current and persistent $\mathrm{Na}^{+}$ current in rat hippocampal pyramidal cells. J Physiol 545:783-805. CrossRef Medline 
Hu H, Vervaeke K, Storm JF (2007) M-channels (Kv7/KCNQ channels) that regulate synaptic integration, excitability, and spike pattern of CA1 pyramidal cells are located in the perisomatic region. J Neurosci 27:18531867. CrossRef Medline

Huang CL, Feng S, Hilgemann DW (1998) Direct activation of inward rectifier potassium channels by $\mathrm{PIP}_{2}$ and its stabilization by $\mathrm{G} \beta \gamma$. Nature 391:803-806. CrossRef Medline

Itou Y, Nochi R, Kuribayashi H, Saito Y, Hisatsune T (2011) Cholinergic activation of hippocampal neural stem cells in aged dentate gyrus. Hippocampus 21:446-459. CrossRef Medline

Jan LY, Jan YN (2012) Voltage-gated potassium channels and the diversity of electrical signalling. J Physiol 590:2591-2599. CrossRef Medline

Jung MW, McNaughton BL (1993) Spatial selectivity of unit activity inthe hippocampal granular layer. Hippocampus 3:165-182. CrossRef Medline

Karschin C, Dissmann E, Stühmer W, Karschin A (1996) IRK(1-3) and GIRK(1-4) inwardly rectifying $\mathrm{K}^{+}$channel mRNAs are differentially expressed in the adult rat brain. J Neurosci 16:3559-3570. CrossRef Medline

Kim HJ, Jeong MH, Kim KR, Jung CY, Lee SY, Kim H, Koh J, Vuong TA, Jung S, Yang H5, Park SK, Choi D, Kim SH, Kang K, Sohn JW, Park JM, Jeon D, Koo SH, Ho WK, Kang JS, et al. (2016a) Protein arginine methylation facilitates KCNQ channel-PIP ${ }_{2}$ interaction leading to seizure suppression. eLife 5:e17159. CrossRef Medline

Kim KS, Duignan KM, Hawryluk JM, Soh H, Tzingounis AV (2016b) The voltage activation of cortical KCNQ channels depends on global $\mathrm{PIP}_{2}$ levels. Biophys J 110:1089-1098. CrossRef Medline

Klinger F, Gould G, Boehm S, Shapiro MS (2011) Distribution of M-channel subunits KCNQ2 and KCNQ3 $\mathrm{K}^{+}$channels in rat hippocampus. Neuroimage 58:761-769. CrossRef Medline

Kobayashi M, Buckmaster PS (2003) Reduced inhibition of dentate granule cells in a model of temporal lobe epilepsy. J Neurosci 23:2440-2452. CrossRef Medline

Kosenko A, Hoshi N (2013) A change in configuration of the calmodulinKCNQ channel complex underlies $\mathrm{Ca}^{2+}$-dependent modulation of KCNQ channel activity. PLOS One 8:e82290. CrossRef Medline

Kosenko A, Kang S, Smith IM, Greene DL, Langeberg LK, Scott JD, Hoshi N (2012) Coordinated signal integration at the M-type potassium channel upon muscarinic stimulation. EMBO J 31:3147-3156. CrossRef Medline

Krook-Magnuson E, Armstrong C, Bui A, Lew S, Oijala M, Soltesz I (2015) In vivo evaluation of the dentate gate theory in epilepsy. J Physiol 593: 2379-2388. CrossRef Medline

Langmead CJ, Austin NE, Branch CL, Brown JT, Buchanan KA, Davies CH, Forbes IT, Fry VA, Hagan JJ, Herdon HJ, Jones GA, Jeggo R, Kew JN, Mazzali A, Melarange R, Patel N, Pardoe J, Randall AD, Roberts C, Roopun A, et al. (2008) Characterization of a CNS penetrant, selective $\mathrm{M}_{1}$ muscarinic receptor agonist, 77-LH-28-1. Br J Pharmacol 154:11041115. CrossRef Medline

Larsen AP (2010) Role of ERG1 isoforms in modulation of ERG1 channel trafficking and function. Pflugers Arch 460:803-812. CrossRef Medline

Lassing I, Lindberg U (1990) Polyphosphoinositide synthesis in platelets stimulated with low concentrations of thrombin is enhanced before the activation of phospholipase C. FEBS Lett 262:231-233. CrossRef Medline

Lawrence JJ, Grinspan ZM, Statland JM, McBain CJ (2006a) Muscarinic receptor activation tunes mouse stratum oriens interneurons to amplify spike reliability. J Physiol 571:555-562. CrossRef Medline

Lawrence JJ, Saraga F, Churchill JF, Statland JM, Travis KE, Skinner FK, McBain CJ (2006b) Somatodendritic Kv7/KCNQ/M channels control interspike interval in hippocampal interneurons. J Neurosci 26:1232512338. CrossRef Medline

Lawrence JJ Statland JM, Grinspan ZM, McBain CJ (2006c) Cell typespecific dependence of muscarinic signalling in mouse hippocampal stratum oriens interneurones. J Physiol 570:595-610. CrossRef Medline

Leão RN, Tan HM, Fisahn A (2009) Kv7/KCNQ channels control action potential phasing of pyramidal neurons during hippocampal gamma oscillations in vitro. J Neurosci 29:13353-13364. CrossRef Medline

Levey AI, Edmunds SM, Koliatsos V, Wiley RG, Heilman CJ (1995) Expression of $\mathrm{m} 1-\mathrm{m} 4$ muscarinic acetylcholin receptor proteins in rat hippocampus and regulation by cholinergic innervation. J Neurosci 15: 4077-4092. CrossRef Medline

Li Y, Langlais P, Gamper N, Liu F, Shapiro MS (2004) Dual phosphorylations underlie modulation of unitary $\mathrm{KCNQ} \mathrm{K}{ }^{+}$channels by src tyrosine kinase. J Biol Chem 279:45399-45407. CrossRef Medline

Li Y, Gamper N, Hilgemann DW, Shapiro MS (2005) Regulation of Kv7
(KCNQ) $\mathrm{K}^{+}$channel open probability by phosphatidylinositol $4,5-$ bisphosphate. J Neurosci 25:9825-9835. CrossRef Medline

Loew LM (2007) Where does all the PIP ${ }_{2}$ come from? J Physiol 582:945-951. CrossRef Medline

Logothetis DE, Mahajan R, Adney SK, Ha J, Kawano T, Meng XY, Cui M (2015) Unifying mechanism of controlling Kir3 channel activity by G proteins and phosphoinositides. Int Rev Neurobiol 123:1-26. CrossRef Medline

Lübke J, Frotscher M, Spruston N (1998) Specialized electrophysiological properties of identified neurons in the hilar region of the rat fascia dentate. J Neurophysiol 79:1518-1534. CrossRef Medline

Lüscher C, Slesinger PA (2010) Emerging roles of G protein-gated inwardly rectifying potassium (GIRK) channels in health and disease. Nat Rev Neurosci 11:301-315. CrossRef Medline

Lüscher C, Jan LY, Stoffel M, Malenka RC, Nicoll RA (1997) G proteincoupled inwardly rectifying $\mathrm{K}^{+}$channels (GIRKs) mediate postsynaptic but not presynaptic transmitter actions in hippocampal neurons. Neuron 19:687-695. CrossRef Medline

Madison DV, Lancaster B, Nicoll RA (1987) Voltage clamp analysis of cholinergic action in the hippocampus. J Neurosci 7:733-741. CrossRef Medline

Madroñal N, Delgado-García JM, Fernández-Guizán A, Chatterjee J, Köhn M, Mattucci C, Jain A, Tsetsenis T, Illarionova A, Grinevich V, Gross CT, Gruart A (2016) Rapid erasure of hippocampal memory following inhibition of dentate gyrus granule cells. Nat Commun 7:10923. CrossRef Medline

Martinello K, Huang Z, Lujan R, Tran B, Watanabe M, Cooper EC, Brown DA, Shah MM (2015) Cholinergic afferent stimulation induces axonal functional plasticity in adult hippocampal granule cells. Neuron 85:346363. CrossRef Medline

Mateos-Aparicio P, Murphy R, Storm JF (2014) Complementary functions of SK and Kv7/M potassium channels in excitability control and synaptic integration in rat hippocampal dentate gyrus granule cells. J Physiol 592: 669-693. CrossRef Medline

McHugh TJ, Jones MW, Quinn JJ, Balthasar N, Coppari R, Elmquist JK, Lowell BB, Fanselow MS, Wilson MA, Tonegawa S (2007) Dentate gyrus NMDA receptors mediate rapid pattern separation in the hippocampal network. Science 317:94-99. CrossRef Medline

Michel FJ, Fortin GD, Martel P, Yeomans J, Trudeau LE (2005) $\mathrm{M}_{3}$-like muscarinic receptors mediate $\mathrm{Ca}^{2+}$ influx in rat mesencephalic GABA neurones through a protein kinase C-dependent mechanism. Neuropharmacology 48:796-809. CrossRef Medline

Miller M, Shi J, Zhu Y, Kustov M, Tian JB, Stevens A, Wu M, Xu J, Long S, Yang P, Zholos AV, Salovich JM, Weaver CD, Hopkins CR, Lindsley CW, McManus O, Li M, Zhu MX (2011) Identification of ML204, a novel potent antagonist that selectively modulates native TRPC4/5 ion channels. J Biol Chem 286:33436-33446. CrossRef Medline

Mucha M, Ooi L, Linley JE, Mordaka P, Dalle C, Robertson B, Gamper N, Wood IC (2010) Transcriptional control of KCNQ channel genes and the regulation of neuronal excitability. J Neurosci 30:13235-13245. CrossRef Medline

Nicoll RA (2017) A brief history of long-term potentiation. Neuron 93:281290. CrossRef Medline

Niday Z, Hawkins VE, Soh H, Mulkey DK, Tzingounis AV (2017) Epilepsyassociated KCNQ2 channels regulate multiple intrinsic properties of layer 2/3 pyramidal neurons. J Neurosci 37:576-586. CrossRef Medline

Nyakas C, Luiten PG, Spencer DG, Traber J (1987) Detailed projection patterns of septal and diagonal band efferents to the hippocampus in the rat with emphasis on innervations of CAl and dentate gyrus. Brain Res Bull 18:533-545. CrossRef Medline

Ordaz B, Tang J, Xiao R, Salgado A, Sampieri A, Zhu MX, Vaca L (2005) Calmodulin and calcium interplay in the modulation of TRPC5 channel activity: identification of a novel C-terminal domain for calcium/ calmodulin-mediated facilitationo. J Biol Chem 280:30788-30796. CrossRef Medline

Otto JF, Kimball MM, Wilcox KS (2002) Effects of the anticonvulsant retigabine on cultured cortical neurons: changes in electroresponsive properties and synaptic transmission. Mol Pharmacol 61:921-927. CrossRef Medline

Pan Z, Kao T, Horvath Z, Lemos J, Sul JY, Cranstoun SD, Bennett V, Scherer SS, Cooper EC (2006) A common ankyrin-G-based mechanisms retains 
KCNQ and $\mathrm{Na}_{\mathrm{v}}$ channels at electrically active domains of the axon. J Neurosci 26:2599-2613. CrossRef Medline

Papke RL, Wecker L, Stitzel JA (2010) Activation and inhibition of mouse muscle and neuronal nicotinic acetylcholine receptors expressed in xenopus oocytes. J Pharmacol Exp Ther 333:501-518. CrossRef Medline

Peters HC, Hu H, Pongs O, Storm JF, Isbrandt D (2005) Conditional transgenic suppression of $\mathrm{M}$ channels in mouse brain reveals functions in neuronal excitability, resonance and behavior. Nat Neurosci 8:51-60. CrossRef Medline

Petrovic MM, Nowacki J, Olivo V, Tsaneva-Atanasova K, Randall AD, Mellor JR (2012) Inhibition of post-synaptic Kv7/KCNQ/ M channels facilitates long-term potentiation in the hippocampus. PLoS One 7:e30402. CrossRef Medline

Ponce A, Bueno E, Kentros C, Vega-Saenz de Miera E, Chow A, Hillman D, Chen S, Zhu L, Wu MB, Wu X, Rudy B, Thornhill WB (1996) G-protein-gated inward rectifier $\mathrm{K}^{+}$channel proteins (GIRK1) are present in the soma and dendrites as well as nerve terminals of specific neurons in the brain. J Neurosci 16:1990-2001. CrossRef Medline

Poolos NP, Johnston D (2012) Dendritic ion channelopathy in acquired epilepsy. Epilepsia 9:32-40. CrossRef Medline

Prakriya M, Lewis RS (2015) Store-operated calcium channels. Physiol Rev 95:1383-1436. CrossRef Medline

Racaud-Sultan C, Mauco G, Guinebault C, Plantavid M, Payrastre B, Breton M, Chap H (1993) Rapid and transient thrombin stimulation of phosphatidylinositol-4,5-bisphosphate synthesis but not of phosphatidylinositol-3,4-bisphosphate independent of phospholipase C activation in platelets. FEBS Lett 330:347-351. CrossRef Medline

Racine RJ (1972) Modification of seizure activity by electrical stimulation. II. Motor seizure. Electroencephalogr Clin Neurophysiol 32:281-294. Medline

Ramsey IS, Delling M, Clapham DE (2006) An introduction to TRP channels. Annu Rev Physiol 68:619-647. CrossRef Medline

Robbins J, Passmore GM, Abogadie FC, Reilly JM, Brown DA (2013) Effects of KCNQ2 gene truncation on M-type Kv7 potassium currents. PLoS One 8:e71809. CrossRef Medline

Roth BL (2016) DREADDs for neuroscientists. Neuron 89:683-694. CrossRef Medline

Rouse ST, Hamilton SE, Potter LT, Nathanson NM, Conn PJ (2000) Muscarinic-induced modulation of potassium conductances is unchanged in mouse hippocampal pyramidal cells that lack functional $\mathrm{M}_{1}$ receptors. Neurosci Lett 278:61-64. CrossRef Medline

Rundfeldt C, Netzer R (2000) The novel anticonvulsant retigabine activates $\mathrm{M}$-currents in chinese hamster ovary-cells transfected with human KCNQ2/3 subunits. Neurosci Lett 282:73-76. CrossRef Medline

Saganich MJ, Machado E, Rudy B (2001) Differential expression of genes encoding subthreshold-operating voltage-gated $\mathrm{K}^{+}$channels in brain. J Neurosci 21:4609-4624. CrossRef Medline

Scharfman HE, Myers CE (2016) Corruption of the dentate gyrus by "dominant" granule cells: implications for dentate gyrus function in health and disease. Neurobiol Learn Mem 129:69-82. CrossRef Medline

Schroeder BC, Kubisch C, Stein V, Jentsch TJ (1998) Moderate loss of function of cyclic-AMP-modulated KCNQ2/KCNQ3 $\mathrm{K}^{+}$channels causes epilepsy. Nature 396:687-690. CrossRef Medline

Schroeder BC, Hechenberger M, Weinreich F, Kubisch C, Jentsch TJ (2000) KCNQ5, a novel potassium channel broadly expressed in brain, mediates M-type currents. J Biol Chem 275:24089-24095. CrossRef Medline

Selyanko AA, Hadley JK, Brown DA (2001) Properties of single M-type KCNQ2/KCNQ3 potassium channels expressed in mammalian cells. J Physiol 534:15-24. CrossRef Medline

Shah MM, Migliore M, Valencia I, Cooper EC, Brown DA (2008) Functional significance of axonal Kv7 channels in hippocampal pyramidal neurons. Proc Natl Acad Sci U S A 105:7869-7874. CrossRef Medline

Shapiro MS, Roche JP, Kaftan EJ, Cruzblanca H, Mackie K, Hille B (2000) Reconstitution of muscarinic modulation of the KCNQ2/KCNQ3 $\mathrm{K}^{+}$ channels that underlie the neuronal M current. J Neurosci 20:1710-1721. CrossRef Medline

Sheffler DJ, Williams R, Bridges TM, Xiang Z, Kane AS, Byun NE, Jadhav S, Mock MM, Zheng F, Lewis LM, Jones CK, Niswender CM, Weaver CD, Lindsley CW, Conn PJ (2009) A novel selective muscarinic acetylcholine receptor subtype 1 antagonist reduces seizures without impairing hippocampus-dependent learning. Mol Pharmacol 76:356-368. CrossRef Medline

Shen W, Hamilton SE, Nathanson NM, Surmeier DJ (2005) Cholinergic suppression of KCNQ channel currents enhances excitability of striatal medium spiny neurons. J Neurosci 25:7449-7458. CrossRef Medline

Singh NA, Charlier C, Stauffer D, DuPont BR, Leach RJ, Melis R, Ronen GM, Bjerre I, Quattlebaum T, Murphy JV, McHarg ML, Gagnon D, Rosales TO, Peiffer A, Anderson VE, Leppert M (1998) A novel potassium channel gene, KCNQ2, is mutated in an inherited epilepsy of newborns. Nat Genet 18:25-29. CrossRef Medline

Singh NA, Otto JF, Dahle EJ, Pappas C, Leslie JD, Vilaythong A, Noebels JL, White HS, Wilcox KS, Leppert MF (2008) Mouse models of human KCNQ2 and KCNQ3 mutations for benign familial neonatal convulsions shows seizures and neuronal plasticity without synaptic reorganization. J Physiol 586:3405-3423. CrossRef Medline

Slesinger PA, Stoffel M, Jan YN, Jan LY (1997) Defective gammaaminobutyric acid type B receptor-activated inwardly rectifying $\mathrm{K}^{+}$currents in cerebellar granule cells isolated from weaver and Girk2 null mutant mice. Proc Natl Acad Sci U S A 94:12210-12217. CrossRef Medline

Sloviter RS, Bumanglag AV, Schwarcz R, Frotscher M (2012) Abnormal dentate gyrus network circuitry in temporal lobe epilepsy. In: Jasper's basic mechanisms of the epilepsies, Ed 4 (Noebels JL, Avoli M, Rogawski MA, Olsen RW, Delgado-Escueta AV eds). Bethesda: National Center for Biotechnology Information.

Soh H, Pant R, LoTurco JJ, Tzingounis AV (2014) Conditional deletions of epilepsy-associated KCNQ2 and KCNQ3 channels from cerebral cortex cause differential effects on neuronal excitability. J Neurosci 34:53115321. CrossRef Medline

Sohn JW, Lim A, Lee SH, Ho WK (2007) Decrease in PIP $_{2}$-channel interactions is the final common mechanism involving PKC- and arachidonic acid-mediated inhibitions of $\mathrm{GABA}_{\mathrm{B}}$-activated $\mathrm{K}^{+}$current. J Physiol 582: 1037-1046. CrossRef Medline

Sotty F, Danik M, Manseau F, Laplante F, Quirion R, Williams S (2003) Distinct electrophysiological properties of glutamatergic, cholinergic and GABAergic rat septohippocampal neurons: novel implications for hippocampal rhythmicity. J Physiol 551:927-943. CrossRef Medline

Strübing C, Krapivinsky G, Krapivinsky L, Clapham DE (2001) TRPC1 and TRPC5 form a novel cation channel in mammalian brain. Neuron 29: 645-655. CrossRef Medline

Suh BC, Hille B (2007) Regulation of KCNQ channels by manipulation of phosphoinositides. J Physiol 582:911-916. CrossRef Medline

Suh BC, Horowitz LF, Hirdes W, Mackie K, Hille B (2004) Regulation of KCNQ2/KCNQ3 current by G protein cycling: the kinetics of receptormediated signaling by gq. J Gen Physiol 123:663-683. CrossRef Medline

Tai C, Hines DJ, Choi HB, MacVicar BA (2011) Plasma membrane insertion of TRPC 5 channels contributes to the cholinergic plateau potential in hippocampal CA1 pyramidal neurons. Hippocampus 21:958-967. CrossRef Medline

Takano H, Coulter DA (2012) Imaging of hippocampal circuits in epilepsy. In: Jasper's basic mechanisms of the epilepsies, Ed 4 (Noebels JL, Avoli M, Rogawski MA, Olsen RW, Delgado-Escueta AV eds). Bethesda: National Center for Biotechnology Information.

Takechi H, Eilers J, Konnerth A (1998) A new class of synaptic response involving calcium release in dendritic spines. Nature 396:757-760. CrossRef Medline

Tatulian L, Brown DA (2003) Effect of the KCNQ potassium channel opener retigabine on single KCNQ2/3 channels expressed in $\mathrm{CHO}$ cells. J Physiol 549:57-63. CrossRef Medline

Tatulian L, Delmas P, Abogadie FC, Brown DA (2001) Activation of expressed KCNQ potassium currents and native neuronal M-type potassium currents by the anti-convulsant drug retigabine. J Neurosci 21: 5535-5545. CrossRef Medline

Telezhkin V, Brown DA, Gibb AJ (2012) Distinct subunit contributions to the activation of M-type potassium channels by $\mathrm{PI}(4,5) \mathrm{P}_{2}$. J Gen Physiol 140:41-53. CrossRef Medline

Thomas RL, Mistry R, Langmead CJ, Wood MD, Challiss RA (2008) G protein coupling and signaling pathway activation by $\mathrm{M}_{1}$ muscarinic acetylcholine receptor orthosteric and allosteric agonists. J Pharmacol Exp Ther 327:365-374. CrossRef Medline

Tuosto L, Capuano C, Muscolini M, Santoni A, Galandrini R (2015) The multifaceted role of PIP $_{2}$ in leukocyte biology. Cell Mol Life Sci 72:44614474. CrossRef Medline

Tzingounis AV, Nicoll RA (2008) Contribution of KCNQ2 and KCNQ3 to 
the medium and slow afterhyperpolarization currents. Proc Natl Acad Sci U S A 105:19974-19979. CrossRef Medline

Tzingounis AV, Heidenreich M, Kharkovets T, Spitzmaul G, Jensen HS, Nicoll RA, Jentsch TJ (2010) The KCNQ5 potassium channel mediates a component of the afterhyperpolarization current in mouse hippocampus. Proc Natl Acad Sci U S A 107:10232-10237. CrossRef Medline

Venkatachalam K, Zheng F, Gill DL (2003) Regulation of canonical transient receptor potential (TRPC) channel function by diacylglycerol and protein kinase C. J Biol Chem 278:29031-29040. CrossRef Medline

Vervaeke K, Gu N, Agdestein C, Hu H, Storm JF (2006) Kv7/KCNQ/Mchannels in rat glutamatergic hippocampal axons and their role in regulation of excitability and transmitter release. J Physiol 576:235-256. CrossRef Medline

Vogt KE, Regehr WG (2001) Cholinergic modulation of excitatory synaptic transmission in the CA3 area of the hippocampus. J Neurosci 21:75-83. CrossRef Medline

Volpicelli LA, Levey AI (2004) Muscarinic acetylcholine receptor subtypes in cerebral cortex and hippocampus. Prog Brain Res 145:59-66. CrossRef Medline

Volpicelli-Daley LA, Lucast L, Gong LW, Liu L, Sasaki J, Sasaki T, Abrams CS, Kanaho Y, De Camilli P (2010) Phosphatidylinositol-4-phosphate 5-kinases and phosphatidylinositol 4,5-bisphosphate synthesis in the brain. J Biol Chem 285:28708-28714. CrossRef Medline

Wang J, Trudeau MC, Zappia AM, Robertson GA (1998) Regulation of deactivation by an amino terminal domain inhuman ether-a-go-go-related gene potassium channels. J Gen Physiol 112:637-647. CrossRef Medline

Winks JS, Hughes S, Filippov AK, Tatulian L, Abogadie FC, Brown DA, Marsh SJ (2005) Relationship between membrane phsophatidylinositol-4,5bisphosphate and receptor-mediated inhibition of native neuronal $\mathrm{M}$ channels. J Neurosci 25:3400-3413. CrossRef Medline

Wright BD, Loo L, Street SE, Ma A, Taylor-Blake B, Stashko MA, Jin J, Janzen WP, Frye SV, Zylka MJ (2014) The lipid kinase PIP5K1C regulates pain signaling and sensitization. Neuron 82:836-847. CrossRef Medline

Wu LJ, Sweet TB, Clapham DE (2010) International union of basic and clinical pharmacology. LXXVI. Current progress in the mammalian TRP ion channel family. Pharm Rev 62:381-404. CrossRef Medline

Wu WW, Chan CS, Surmeier DJ, Disterhoft JF (2008) Coupling of L-type $\mathrm{Ca}^{2+}$ channels to Kv7/KCNQ channels creates a novel, activitydependent, homeostatic intrinsic plasticity. J Neurophysiol 100:18971908. CrossRef Medline

Xu C, Loew LM (2003) Activation of phospholipase C increases intramembrane electric fields in N1E-115 neuroblastoma cells. Biophys J 84:41444156. CrossRef Medline

Xu C, Watras J, Loew LM (2003) Kinetic analysis of receptor activated phosphoinositide turnover. J Cell Biol 161:779-791. CrossRef Medline

Xu C, Xie H, Guo X, Gong H, Liu L, Qi H, Xu C, Liu W (2017) A PIP $2^{-}$ derived amplification loop fuels the sustained initiation of $\mathrm{B}$ cell activation. Sci Immunol 2:eaan0787. CrossRef Medline

Yang LP, Jiang FJ, Wu GS, Deng K, Wen M, Zhou X, Hong X, Zhu MX, Luo HR (2015) Acute treatment with a novel TRPC4/C5 channel inhibitor produces antidepressant and anxiolytic-like effects in mice. PLoS One 10:e0136255. CrossRef Medline
Yue C, Yaari Y (2004) KCNQ/M channels control spike afterhyperpolarization and burst generation in hippocampal neurons. J Neurosci 24:46144624. CrossRef Medline

Yue C, Yaari Y (2006) Axo-somatic and apical dendritic Kv7/M channels differentially regulate the intrinsic excitability of adult rat CA1 pyramidal cells. J Neurophysiol 95:3480-3495. CrossRef Medline

Zaczek R, Chorvat RJ, Saye JA, Pierdomenico ME, Maciag CM, Logue AR, Fisher BN, Rominger DH, Earl RA (1998) Two new potent neurotransmitter release enhancers, 10,10 -bis(4-pyridinylmethyl)-9(10H)-anthracenone and 10,10-bis(2-fluoro-4-pyridinylmethyl)-9(10H)-anthracenone: comparison to linopirdine. J Pharmacol Exp Ther 285:724-730. Medline

Zaika O, Tolstykh GP, Jaffe DB, Shapiro MS (2007) Inositol triphosphatemediated $\mathrm{Ca}^{2+}$ signals direct purinergic $\mathrm{P} 2 \mathrm{Y}$-receptor regulation of neuronal ion channels. J Neurosci 27:8914-8926. CrossRef Medline

Zaika O, Hernandez CC, Bal M, Tolstykh GP, Shapiro MS (2008) Determinants within the turret and pore-loop domains of KCNQ3 $\mathrm{K}^{+}$channels governing functional activity. Biophys J 95:5121-5137. CrossRef Medline

Zaika O, Zhang J, Shapiro MS (2011) Combined phosphoinositide and $\mathrm{Ca}^{2+}$ signals mediating receptor specificity toward neuronal $\mathrm{Ca}^{2+}$ channels. J Biol Chem 286:830-841. CrossRef Medline

Zhang H, Craciun LC, Mirshahi T, Rohács T, Lopes CM, Jin T, Logothetis DE (2003) PIP $_{2}$ activates KCNQ channels, and its hydrolysis underlies receptor-mediated inhibition of $\mathrm{M}$ currents. Neuron 37:963-975. CrossRef Medline

Zhang J, Carver CM, Choveau FS, Shapiro MS (2016) Clustering and functional coupling of diverse ion channels and signaling proteins revealed by super-resolution STORM microscopy in neurons. Neuron 92:461-478. CrossRef Medline

Zhang J, Shapiro MS (2012) Activity-dependent transcriptional regulation of M-type (Kv7) $\mathrm{K}^{+}$channels by AKAP79/150-mediated NFAT actions. Neuron 76:1133-1146. CrossRef Medline

Zhang J, Bal M, Bierbower S, Zaika O, Shapiro MS (2011) AKAP79/150 signal complexes in G-protein modulation of neuronal ion channels. J Neurosci 31:7199-7211. CrossRef Medline

Zheng F (2017) TRPC channels and epilepsy. Adv Exp Med Biol 976:123135. CrossRef Medline

Zhou P, Yu H, Gu M, Nan FJ, Gao Z, Li M (2013) Phosphatidylionositol 4,5-bisphosphate alters pharmacological selectivity for epilepsy-causing KCNQ potassium channels. Proc Natl Acad Sci U S A 110:8726-8731. CrossRef Medline

Zhou Z, Neher E (1993) Mobile and immobile calcium buffers in bovine adrenal chromaffin cells. J Physiol 469:245-273. CrossRef Medline

Zhu H, Aryal DK, Olsen RH, Urban DJ, Swearingen A, Forbes S, Roth BL, Hochgeschwender U (2016) Cre-dependent DREADD (designer receptors exclusively activated by designer drugs) mice. Genesis 54:439-446. CrossRef Medline

Zhu Y, Lu Y, Qu C, Miller M, Tian J, Thakur DP, Zhu J, Deng Z, Hu X, Wu M, McManus OB, Li M, Hong X, Zhu MX, Luo HR (2015) Identification and optimization of 2-aminobenzimidazole derivatives as novel inhibitors of TRPC4 and TRPC5 channels. Br J Pharmacol 172:3495-3509. CrossRef Medline 